\title{
BOOKS ON ASTROLOGY, ASTRONOMICAL TABLES, AND ALMANACS IN THE LIBRARY INVENTORY OF BAYEZID II
}

Paratextual elements in manuscripts often offer surprising clues as to the different stages of transmission a particular copy has undergone. Take, for instance, the Süleymaniye Library Ayasofya Collection MS 2595, a thirteenth-century Persian translation of a popular medieval illustrated star catalogue, Kitāb șuwar al-kawākib (The Book of Constellations of Fixed Stars), produced originally in Arabic in the tenth century by 'Abd al-Rahman al-Sufi (d. 986). ${ }^{1}$ Several marks on the title page and colophon of the manuscript reveal information about its date of composition as well as the subsequent chain of owners/readers during its circulation in the next few centuries.

The colophon on folio $97 \mathrm{~b}$ states that the famous polymath and founder of the Maragha observatory, Nasir al-Din al-Tusi (d. 1274), completed this Persian translation on Monday, 25 Dhu'l-Qa'da 647 (March 1, 1250). Next to this colophon is a statement written horizontally in another hand, indicating that the book had been penned by Tusi himself and was later acquired in Baghdad in the year $805(1402-3)$ by the Jalayirid ruler Ahmad b. Shaykh Uways (d.1410). There are yet other possession statements on the title page (fol. 1a): what seems to be the earliest one, li-aḥwaj khalq Allāh Ulugh Bìg (for the most needy of created beings, Ulugh Beg), refers to Ulugh Beg (d. 1449), the famous Timurid ruler and founder of the Samarqand observatory. Above this note is the endowment (waqf) statement and seal of the Ottoman sultan, Mahmud I (r. 1730-54). At the bottom of the same page is the impression of yet another stamp, the idiosyncratic almond-shaped seal of Bayezid II (r. 1481-1512). The same seal is also stamped on the colophon page, documenting without any doubt that the manuscript was in the Ottoman imperial treasury by the turn of the sixteenth century.
In addition to the colophon and possession statements, two different versions of the book title are recorded on the title page of the manuscript. The short one just above the seal of Mahmud I reads: Kitāb șuwar alkawākib tarjama-i Khwāja Nașīr (The Book of Constellations of Fixed Stars, Translated by Master al-Nasir [al-Tusi]). The second, longer title is inscribed at the top of the page in the hand that apparently penned the titles of many other surviving manuscripts bearing Bayezid II's oval seal. This title reads: Kitāb tarjama kitāb șuwar al-kawākib bi-al-fārsiyya marqūm bi-annahu bi-khațt mutarjimihi alladhì huwa al-Nașìr al-Ṭūsì min qibal alnujüm (The [Persian] Translation of the Book of Constellations of Fixed Stars, Marked as the Autograph Copy of Its Translator, al-Nasir al-Tusi, Pertaining to [the Science of] the Stars). This longer version of the title is repeated verbatim in 'Atufi's inventory (see list of entries $[126] /[158])$ dated $908(1502-3)$, a clean copy of which was produced the following year in $909(1503-4) .^{2}$

The documented circulation of this particular manuscript - first from the Ilkhanids to the Jalayirids, then from the Jalayirids to the Timurids, and finally from the Timurids to the Ottomans-embodies the otherwise relatively abstract notion of the transmission of scientific knowledge and ideas. The curious stories offered by such surviving copies stimulate the historian's imagination with the detailed logs of the movement of manuscripts across wide territories. That books were presented as personal or diplomatic gifts, or that valuable objects, including manuscripts, were at times of military encounter seized by the conquering party, can explain how written materials were transmitted from one courtly context to another. The physical transition of manuscripts may also be correlated with the simultaneous movement of scholars accompanied by their 
retinues who carried their possessions between distant locations. In the particular case of Tusi's Persian translation of the star catalogue, which later passed into the hands of Ulugh Beg, the recounted arrival of the astronomer 'Ali al-Qushji (d. 1474) to Istanbul around 1472, with nearly two hundred people in his entourage, may provide a compelling explanation for the eventual journey of this copy-along with many other relevant items listed in 'Atuf's inventory-from the Timurid to the Ottoman realm. ${ }^{3}$ Undoubtedly, the coming of al-Qushji to Istanbul was not the only occasion for the accumulation of works on different branches and genres of celestial knowledge in the Ottoman capital. But regardless of how each item ended up in the Ottoman palace, the relevant holdings of the palace library as documented in 'Atufi's inventory neatly reflect the strong influence of post-thirteenth-century astral lore from the Persianate East, specifically of works descending from the Maragha and Samarqand "schools," on the formation and collection of a noteworthy astral canon in late fifteenth- to early sixteenth-century Istanbul. ${ }^{4}$ The primary aim of the present article is to discuss the general contours of this influence based on the relevant catalogue section in 'Atufi's inventory that lists books on astrological and other practical celestial pursuits, which he groups under the following rubrics: 'ilm al-nujüm (science of the stars), min qibal al-nujūm (pertaining to the stars), or ahkāmalnujūm (decrees of the stars, i.e., astrology sensu stricto).

In order to avoid potential confusion, we should note at the outset that the modern distinction between astrology and astronomy does not fully correspond to the disciplinary boundaries that existed in the medieval and early modern scientific culture of the Islamicate world, or elsewhere. The boundaries between 'ilm al-hay'a (namely, the science of the structure or configuration [of the entire universe], i.e., astronomy) and 'ilm (or șinā'at) ahkām al-nujūm (namely, the science or art of the decrees of the stars, i.e., astrology), which emerged and consolidated as early as the ninth century according to George Saliba, were not always categorically followed in late medieval and early modern astral lore in the Persianate East. This was especially the case for works that deal primarily with the practical application of celestial knowledge. ${ }^{5}$
As a general rule, the relevant works in the astral lore of the post-thirteenth-century Persianate East also implied a distinction between hay'a and nujūm. Whereas the former term ('ilm al-hay'a) was employed to describe theoretical celestial knowledge that "sought a coherent physical cosmography based on mathematical models," the category 'ilm al-nujūm was used more as a blanket term, encompassing different branches and genres that dealt with the practical implications of celestial knowledge, including astrology. ${ }^{6}$ Works that modern historiography facilely groups together as "astronomical texts," such as $z \bar{j}$ jes (handbooks of tables used for astronomical, astrological, and calendrical purposes) or treatises on instruments like astrolabes, conveyed information necessary for astrological calculations. ${ }^{7}$ Indeed, astrological practice, which depended in principle on drawing infer-

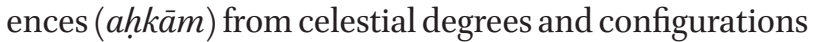
in a given moment at a particular locality, would not have been possible without the astronomical data and parameters of calculation offered by these texts. Authoritative ancient and medieval sources such as Ptolemy (d. ca. 170), Biruni (d. ca. 1050), and Tusi are all explicit on this point, declaring that a precise mathematical knowledge of celestial positions was what the munajjims (astrologers/astronomers) needed to practice their craft, particularly for casting horoscopes and preparing almanacs with prognostications (taqwims). ${ }^{8}$ The urge in the post-thirteenth-century Persianate East to establish observatories and conduct systematic celestial observations was also intimately related to improving the precision of celestial data and parameters, which the astral experts needed for their calculations. ${ }^{9}$

A more detailed discussion of 'Atufi's terminology and treatment of available titles in the library will follow in the pages to come. But suffice it to say now that compared to the number of titles strictly related to the theoretical genre of 'ilm al-hay'a (which is around 130 by our count), the inventory contains a greater number of works (about 200) in the abovementioned genres, which can be defined, for the sake of simplicity, as astrology and practical astronomical endeavors (['ilm] al-nujūm, min qibal al-nujūm, [ $\left.{ }^{[} i l m\right]$ ahkām al-nujūm). ${ }^{10}$ In our examination of the listed items on astrological and/or practical celestial pursuits in the imperial library, we will supplement 'Atufi's inventory with concrete evidence 
from relevant contemporaneous texts and tables, particularly those produced during the reign of Bayezid II, whose genuine astral interests were noted in a wide array of contemporary sources. We will also examine the systematic set of annual almanacs routinely composed by practicing Ottoman munajjims, and track the scholarly references therein to assess more accurately the extent to which the library collection reflects the trends of contemporary astral practitioners. We will also draw on these late fifteenth- and early sixteenth-century taqwims, some of which have the almond-shaped seal of Bayezid II but curiously are not listed in the inventory, for further speculation on the inner workings of the imperial library, as well as to assess the logic deployed by 'Atufi in preparing his inventory. Finally, we will focus on 'Atuf's categorization of titles pertaining to different branches and genres of celestial knowledge, and point to its remarkable deviation from other, more canonical classification systems adopted in the early modern Ottoman intellectual setting by relatively better-known, later figures like Taşköprizade Ahmed (d. 1561), Nev'i Efendi (d. 1599), and Katib Çelebi (d. 1657).

\section{CELESTIAL PURSUITS AT THE OTTOMAN COURT,} 1470S TO $1510 \mathrm{~S}$

At the time al-Qushji arrived in Istanbul, systematic scholarly activity on celestial knowledge was only in its infancy in the Ottoman realm. ${ }^{11}$ As a matter of fact, several treatises of Tusi were already in circulation in the lands of Rūm during the fourteenth and first half of the fifteenth century, such as his introductory textbook on the astrological indications of planets, zodiac signs, and planetary aspects titled Si fașl or Mukhtașar dar ma'rifat-itaqvim (Thirty Chapters on Almanacs), his Zïj-i ìlkhānī (Ilkhanid Astronomical Handbook of Tables), and his al-Tadhkira fi 'ilm al-hay'a (Memoir on Astronomy). ${ }^{12}$ The Fenari circle in western Anatolia, including such members as the prominent scholar Molla Fenari (d. 1431) and the Khurasan-born 'Abdulwajid b. Muhammad (d. 1435), was also well informed about the scientific output of the Maragha school. ${ }^{13}$

Yet anecdotal and archival evidence about the students of celestial knowledge in the fifteenth century indicates that Ottoman territory was not the ideal place for a would-be expert to excel in the science of the stars at the time. For instance, Qadizade al-Rumi (d. after 1440), one of the intellectual founders of the Samarqand observatory, grew up in Bursa and received his first education within the Fenari circle. But his master MehmedShah Fenari (d. 1436), the son of Molla Fenari, still felt compelled to suggest that his brilliant student should travel to Iran and Central Asia to further his quest in astral lore. ${ }^{14}$ In a similar vein, a certain 'Abdurrahman Munajjim (d. after 1510), who served at the princely court of Bayezid II's son Şehzade Ahmed (d. 1513) in Amasya no later than the early 1490 s, writes in an autobiographical passage that after studying the basics of the science of the stars ('ilm al-nujūm) with Mevlana Kuçek al-Amasi (d. after 1481) - also known as Mevlana Yazdanbakhsh, the only documented court munajjim in the final years of Mehmed II's reign (r. 1444-46, 1451-81)—Şehzade Ahmed recommended that he go to the lands of Iran (diyār al-'Ajam) to advance his knowledge in the discipline. ${ }^{15}$ Besides hinting at the embryonic state of systematic astral production in the Ottoman territories throughout the fifteenth century, these details clearly suggest that in the eyes of the fifteenth-century stargazers active in the Ottoman lands, the Persianate East was the main point of reference and locus for gaining proficiency in the science of the stars.

The exact historical details of 'Ali al-Qushji's arrival in Istanbul are still obscure, though anecdotal evidence extracted from various near-contemporary sources clearly shows that Mehmed II went to great lengths to bring him to the Ottoman capital. The former Aqqoyunlu scholar who joined Bayezid II's court, Idris-i Bidlisi (d. 1520), even says that Mehmed II promised to enable al-Qushji to continue his unfinished observation program in Istanbul. ${ }^{16}$ Mehmed II's genuine interest in recruiting al-Qushji seems to have been related to the political prestige and instrumentality accorded to the patronage of the science of the stars in late medieval and early modern courtly culture. ${ }^{17}$ Yet the sultan's urgent need to lure an astral expert of the caliber of al-Qushji, and the authority granted him to reorganize the entire Ottoman scholarly hierarchy, could be interpreted as another sign of the inadequacy of systematized celestial 
pursuits in the Ottoman empire during the last third of the fifteenth century. ${ }^{18}$

'Ali al-Qushji could only serve the Ottoman polity for two years before he passed away in 1474, followed by the death of his patron Mehmed II in 1481. Celestial pursuits and systematic attempts to cultivate the science of the stars at the Ottoman court, however, did not come to a halt. Bayezid II, who has often been derided in modern historiography for allegedly hampering the intellectual and scientific achievements attained-or at least initiated-during the reign of his "enlightened" father, was in fact an even more avid patron and eager student of the science of the stars. As we have demonstrated in greater detail elsewhere, from his gubernatorial years in Amasya to his relatively long sultanate in Istanbul, Bayezid II actively sought expertise in this science, put a sizeable group of munajjims on the palace payroll, commissioned a number of treatises on different aspects of astral knowledge, and even spent his own spare time studying the science. ${ }^{19}$ The broad celestial and (occult) philosophical interests of Bayezid II were so widely acknowledged during his lifetime that one of his contemporaries, an anonymous Sufi shaykh, privately complained in a letter apparently addressed to Bayezid II about the "worthless" efforts of the sultan to study these sciences in a formal fashion. ${ }^{20}$

What the anonymous shaykh alludes to in his letter may be related to Bayezid II's decision in the 1490s to call upon Mahmud b. Muhammed b. Qadizade al-Rumi, better known as Mirim Çelebi (d. 1525), to tutor him in the "mathematical sciences" (i.e., al-'ulūm al-riyādiyya), which conventionally comprised astral sciences (hay'a and nujūm), along with geometry (handasa), arithmetic (hisāb), and music $(m \bar{u} s \bar{\imath} q \bar{\imath}) .{ }^{21}$ Descending from a family that included such stellar figures as Qadizade al-Rumi and 'Ali al-Qushji, the young Mirim Çelebi was a direct heir to the post-thirteenth-century astral tradition of the Persianate East in addition to being learned in the Hellenistic astrological heritage. Beyond Mirim Çelebi's service as the sultan's private tutor, Bayezid II also asked him to compose a commentary on the Ulugh Beg tables (Zijj-i Ulugh Beg) that was produced in the Samarkand observatory through the concerted efforts of its members, including Ghiyath al-Din Jamshid al-Kashi (d. 1429), Qadizade al-Rumi, and 'Ali al-Qushji. Com- pleted in the year 1499, Mirim's commentary was later catalogued in 'Atufi's inventory (list of entries [74]/ [185]). ${ }^{22}$ As indicated by the specific supplication (sallamahu) used in the relevant entry, Sharh-i Zïj-i Ulugh Beg li-Mawlānà Mìrim Çelebi sallamahu Allāhu ta'ālā fì al-nujūm (Commentary on Ulugh Beg's Astronomical Handbook of Tables by our master Mirim Çelebi, God keep him safe), which is repeated verbatim on the title page of the surviving autograph copy of the text (SK, Ayasofya MS 2697), 'Atufi must have known Mirim Çelebi personally. ${ }^{23}$ While 'Atufi is reported by Taşköprizade to have studied the rational sciences at the feet of Mirim Çelebi's apparently elder brother, Qutb al-Din Muhammed b. Muhammed b. Qadizade al-Rumi (fl. second half of the fifteenth century), Mirim and 'Atufi studied together 'ilm al-ușūl (the science of principles [of jurisprudence]) under Hocazade (Khajazada) Muslih al-Din (d. $1487-88){ }^{24}$

It is difficult to determine with certainty how long Mirim Çelebi tutored the sultan and which books featured in these studies. As far as the surviving archival documents and contemporary narrative sources are concerned, Mirim Çelebi remained in the close circle of Bayezid II until the sultan's death. ${ }^{25}$ One indication of the books Bayezid II likely studied with Mirim Çelebi is a list of surviving manuscripts in which are found special inscriptions that, in addition to the standard almondshaped seal, suggest the book was personally owned by the sultan: șâhibuhu al-Sulțān Bāyezìd b. Mehemmed Khān ("its owner is Sultan Bayezid"), or sometimes min kutub al-Sulțān Bāyezìd b. Mehemmed Khān ("from among the books of Sultan Bayezid").

What should we understand from these supplementary inscriptions that register such items as the personal property of the sultan? In what respects was a book with the almond-shaped seal different from a copy with both the seal and ex-libris inscription? Was there any clearly defined distinction between the books kept in the imperial treasury and the personal collection of the sultan, in terms of the space in which they were preserved, their accessibility, and their use? What percentage of the personal items Bayezid once held as a prince were transferred to the palace library and processed accordingly, and which works that were already located in the palace 
book treasury became reserved for the private use of the sultan?

It is difficult to provide substantial answers to these questions, as paratextual components in the surviving manuscripts fall short of presenting conclusive evidence. It is striking, though, that many of the cited works in astral lore, both theoretical and practical, constitute the great majority of surviving manuscripts that bear an attestation of Bayezid's personal ownership. Among those books bearing șăhibuhu statements that Bayezid likely studied, we should note the following:

i. $\quad$ Nasir al-Din al-Tusi's Sī faṣl; ${ }^{26}$

ii. (Tusi's) Züj-i ïlkhānī; ${ }^{27}$

iii. (Tusi's) Tahrīr al-Majisțī (Recension of Ptolemy's Almagest); ${ }^{28}$

iv. (Tusi's) Tadhkira fí 'ilm al-hay'a; ${ }^{29}$

v. Mukhtașar madkhal ilā 'ilm ahkām al-nujūm (The Epitome of the Introduction to Astrology), 'Ali b. Ahmad Balkhi's (fl. twelfth century) astrological introduction in both the Arabic original and a Persian rendition; 30

vi. The Epistle of Ikhwan al-Safa on mathematical sciences including the science of the stars; ${ }^{31}$

vii. Anonymous Risāla al-lubāb fì al-usțurlāb (The Quintessence on the Astrolabe); ${ }^{32}$

viii. al-Dirini's (d. 1297) Kitāb yawāqūt al-mawāqūt min qibal al-nujūm (Rubies of Timekeeping, an introductory work in verse on the astronomical/astrological calculation of time); ${ }^{33}$

ix. Abu al-Hasan 'Ali Marrakushi's (fl. late thirteenth century) summa on astronomical instrumentation and computation of time, Jāmi' al-mabādi' wa-alghāyātfì ilm al-mīqāt (Comprehensive Collection of Principles and Goals in the Science of Timekeeping); ${ }^{34}$

x. A majmū'a (compendium) containing Qusta b. Luqa al-Ba'labakki's (d. ca. 912-13) Risāla fíal-'amal bi-al-kura al-falakiyya (Treatise on Using the Celestial Globe) as well as (pseudo-)Aristotle's Risāla al-ghälib wa-al-maghlūb (The Victorious and the Vanquished), a small treatise on a prognosticative technique deployed to predict the outcome of a battle, which was quite popular among Ottoman taqwim writers. ${ }^{35}$

\section{TRACING THE ALMANACS (TAQWĪMS)}

Even more curious than the personal ownership notices of Bayezid II is a set of almanacs with prognostications (taqwims) composed in the first decade of the sultan's reign and embossed with his idiosyncratic almondshaped seal that appear to be uncatalogued in 'Atufi's inventory. ${ }^{36}$ While there are approximately thirty surviving Ottoman taqwims that were composed before the compilation of the library inventory, only three of them bear the seal of Bayezid II. The earliest of these three taqwims was compiled by Khitabi-i Lahijani (d. after 1495) on the occasion of the new (solar) year in 1489 and is now preserved in the Topkapı Palace Museum Library's Bağdad Collection (TSMK B. 310). ${ }^{37}$ The other taqwims with Bayezid's seal are two anonymous ones from the year 1490, one of which is preserved in the same collection (TSMK B. 311) and the other is in the Istanbul Kandilli Observatory Library (MS 365 ).

The ephemeral nature of annual almanacs might have played a role in their exclusion from 'Atufi's inventory. Despite the fact that almost all extant Ottoman taqwims are in codex form, they appear to have been considered different from regular books in some respect. The most obvious difference is that they were produced annually and also expired annually. Early modern Ottoman readers were certainly aware of the ephemeral nature of taqwims. For instance, one malhama text (a prognosticatory writing related to celestial and meteorological phenomena) produced in the late fifteenth century reminds its readers that taqwims are rendered ineffective every new year, whereas the malhama text would survive for many more years to come ( takvim gibi yılda bir żāyic olmaz). ${ }^{38}$ In a similar vein, Katib Çelebi contrasts his Taqwīm al-tawārīkh (Chronological Tables) with the taqwims of munajjims, which, he states, by nature annually become invalid (takvimm-i aṣhāab-i tencìm gibi mensūhü'l-'amel). ${ }^{39}$

The three aforementioned stamped taqwims from 1489 and 1490 imply that the seal of Bayezid II was applied immediately after the codices were presented to the court, and not around the time 'Atufi started working on the copies available in the treasury to prepare his inventory. Otherwise, one would expect to find the almond-shaped seal in many of the other surviving 
taqwims from 1421 to 1503 , most of which are still preserved today in the Topkapı Palace Museum Library collections. This suggests that the custom of impressing the presented copies of manuscripts with the stamp of Bayezid II might have already been practiced in the late 1480s. Unfortunately, there is no extant taqwim from the reign of Bayezid II composed prior to 1489; hence, we are not in a position to confirm whether those taqwims produced in the early 1480 s would have borne the seal. Yet it seems credible to assume that at a certain juncture, likely around 1490, a final decision was reached to no longer stamp taqwims with the sultan's almond-shaped seal.

Notwithstanding the fact that taqwims, even ones bearing the almond-shaped seal, are not listed in 'Atufi's inventory, their contents are crucial for tracking the scholarly references of contemporary astral experts and evaluating more precisely the scope of the palace library vis-à-vis the authoritative texts in astral sciences held therein. We should briefly note that, with all due respect to the significant differences between various examples, a taqwim is, in principle, an annual presentation combining astronomical, astrological, and calendric information with regard to the upcoming solar year. Seemingly ubiquitous throughout medieval and early modern Islamicate culture, especially in the eastern lands, these texts were produced by experts in the science of stars around the time of the year-transfer ( $\operatorname{tahww} \bar{l}-i$ sa $l$ ), that is, the spring equinox and the beginning of the new solar year (nawrüz). ${ }^{40}$

The preparation of these texts required the astral expert to make mathematical and astronomical computations of the celestial positions at the exact moment of the year-transfer, which was necessary for deriving astrological judgments. After identifying the ascendant $\left(t \underline{a} l i^{i}\right)^{41}$ at the time of the year-transfer and establishing other astrological houses by drawing upon the data and methods provided by zijjes in circulation, the taqwim compiler could prepare the horoscope of the coming year. Then he would begin to delineate astrological predictions as to the fortunes of different social categories of people and earthly affairs. In a taqwim, the detailed astrological section in prose is followed by the laborious tabulation of astronomical, astrological, and calendric information for each solar month of the upcoming year.
Here the taqwim writer would place ephemeris tables to mathematically demonstrate the celestial positions in each and every day of the month, to mark the corresponding days in the lunar calendar, and to designate the days of religious and liturgical significance in various traditions. These monthly tables are juxtaposed with astrological remarks in the form of inferences of omens (ậkām) and recommendations for auspicious times to undertake various activities (ikhtiyārāt), based on the interpretation of the individual horoscope of each month as well as the computed planetary aspects. ${ }^{42} \mathrm{Fi}$ nally, the last section of a taqwim is devoted to the eclipses expected in the upcoming year. If an eclipse was anticipated in that year, information about its projected time, location, and duration would be recorded, along with its astrological interpretation.

As is clear from this brief summary of the contents of surviving taqwims, there were two major items a munajjim categorically needed to prepare for an accurate taqwim: (i) a valid $z \bar{j} j$ to accurately calculate the celestial positions in a given time for a given locality, and (ii) a working astrological textbook describing the dispositions of planets and signs as well as the indications of celestial positions. An astronomical instrument that would help the practicing munajjim determine the required celestial positions more easily and accurately was rather optional, as it was likely unaffordable for many a practitioner. ${ }^{43}$

While the $z \bar{j}$ tradition in the Islamicate context dates as far back as the eighth century, with more than 200 such works in different lengths and levels of sophistication surviving to date, a close examination of Ottoman taqwims reveals that munajjims in the service of the Ottoman court clearly favored the ones prepared in the post-thirteenth-century Persianate East as the fruits of systematic observation programs. ${ }^{44}$ This period was characterized by a heightened interest in conducting systematic observational programs ( $\mathrm{rasad}$ ) in the newly established observatories to revise the data and parameters conveyed through astronomical tables (zijjes). At the end of each systematic observation a new $z \bar{j}$ was introduced, with revised figures. The $Z \bar{i} j-i \bar{l} l k h \bar{a} n \bar{\imath}$, for example, was produced no later than the early $1270 \mathrm{os}$ by $\mathrm{Na}-$ sir al-Din al-Tusi and his collaborators as part of the brief observational enterprise at the Maragha observatory. 
Despite Tusi's high expectations for his work, the Zijj-i ìlkhānì did not win much favor among his contemporaries due to its dated parameters and the limited timespan of actual observations prior to its preparation. Thus, soon after its publication, several experts in astral sciences, including 'Ali-Shah Bukhari (d. after 1291), Shams al-Din Muhammad al-Wabkanawi (d. ca. 1320), and Nizam al-Din al-Nisaburi (d. ca. 1329-30), expressed criticisms of the $Z \bar{u}$-i $i$ ilkhānīin their own compilations of tables. ${ }^{45}$ Finally, in the first half of the fifteenth century, the Samarqand observatory was established on the initiative of Ulugh Beg, who gathered an impressive array of astral experts, such as Ghiyath al-Din Jamshid alKashi, Qadizade al-Rumi, and 'Ali al-Qushji, to conduct a systematic observational enterprise. At the end of this observational program a new $z i j$ was composed that came to be known as the Zij-i Ulugh Beg (Ulugh Beg Tables) or Zïj-ijadīd-i sulțānī (The New Royal Tables).

In surviving fifteenth- and sixteenth-century Ottoman taqwims, munajjims often cite explicitly which $z \bar{i} j$ they consulted to make the necessary celestial calculations. Half of the eighteen extant Ottoman taqwims compiled between 1489 and the year 'Atufi completed his inventory cite as their main source the Verified Ilkhanid Tables (Zïj al-muhaqqaq al-ilkhānī) that can be attributed to Wabkanawi, whereas four taqwims made use of the Ulugh Beg tables and only two utilized the Ilkhanid tables. ${ }^{46}$ From the 1510 s up until the late sixteenth century, when the most famous Ottoman astronomer of all times, Taqi al-Din (d. 1585), prepared new tables on the basis of his limited observations in the Istanbul observatory, practicing Ottoman munaijims almost exclusively utilized and cited the Zïj-i Ulugh Beg. ${ }^{47}$

Although the $z \bar{i}$ collection in the palace library largely reflects the general leanings among practicing munajjims toward the post-Maragha $z \bar{i} j$ tradition in Persian, it is rather surprising not to come across a single explicit reference to Wabkanawi's Verified $Z \bar{i} j$ within the palace holdings, given that most court munaijims at the time seem to have based their calculations upon it. ${ }^{48}$ Another remarkable detail about the $z \bar{j} j$ es collected in the imperial treasury is the relatively high number of Nizam al-Din Nishaburi's Kashf-i haqā’iq-i Zīj-i ìlkhānī (Uncovering of the Truths of the Ilkhanid Astronomical Handbook of Tables) ${ }^{49}$ Among the twenty-six copies specifically listed as $z \bar{y}$ es in the inventory and their commentaries - with the exception of the two copies of al-Biruni's al-Qānūn al-Mas üdi, which can indeed be regarded as a $z \bar{j}$ - five of them (list of entries [76]-[80]) are Nishaburi's Kashf-i haqā'iq, to which contemporary Ottoman munajjims seem to have paid little attention. Similarly, there are two copies of Jamshid al-Kashi's Zìj-i khāqāni fìtakmīl-iZīj-i ìlkhānī (Astronomical Tables for the Great Khan Prepared for Completing [Tusi's] Ilkhanid Tables) in the palace library (list of entries [44], [45]), although in none of the surviving fifteenth-and sixteenth-century taqwims is Kashi's $z \bar{\imath} j$ preferred. As for the Zīj-i i lkhāni and $Z \bar{i}$-i $i$ Ulugh Beg, 'Atufi's inventory lists five copies of each (the former: [164]-[168]; the latter: [178]-[182]). Also cited are two copies of 'Ali al-Qushji's commentary on Zïj-i Ulugh Beg (list of entries [112]/[183], [113]/[184]), and one copy of Mirim Çelebi's commentary on the same text (list of entries [74]/[185]). However, it should be noted that these commentaries were written more in order to explain in prose the challenging parts of the Ulugh Beg tables than to publish new tables; thus, they might not have been used in actual computations. It is also worth noting that the $z \bar{y}$ Mevlana Kuçek al-Amasi composed and dedicated to Bayezid II at his gubernatorial seat in Amasya, evidently before January 1477, also ended up in the palace library by the turn of the sixteenth century (list of entries [69]). ${ }^{50}$ Regarding the $z \overline{y j}$ es composed prior to the thirteenth century, the palace library inventory seems to contain only two items: one copy of Kushyar ibn Labban's (d. after 1025) al-Zij al-Jāmic (Comprehensive Astronomical Handbook of Tables, list of entries [65]), and one copy that may be attributed to Abu'l-Wafa' Buzjani (d. 997-98), which 'Atufi catalogues as Zīj maw d̄ū' 'alā mā șaḥhahahu al-Shaykh Abū al-Wafā'wa-aṣhābuhu (Tables Set Forth according to What Was Corrected by the Master Abu al-Wafa' and His Colleagues) (list of entries [24]). ${ }^{51}$ As another indication of the supremacy of the Persianate astral tradition in the early sixteenth-century Ottoman world, $a l-Z i j$ al-jadìd (The New Astronomical Handbook of Tables) of the famed Mamluk astronomer Ibn al-Shatir (d. ca. 1375) is cited neither in the palace library inventory nor in any of the contemporary taqwims.

In addition to having the ability to extract the necessary celestial data from $z \bar{j}$ es, the munajjims had to have 
a sound knowledge of the nature and indications of planets, signs, astrological houses, and planetary aspects. Although there were several alternative textbooks and summae of astrological principles circulating at the time, the authoritative texts and names quoted heavily in the Ottoman taqwims and other horoscopes whenever the need to justify a specific astrological indication arose can be grouped as follows:

i. Kitāb al-thamara (Centiloquium or One Hundred Astrological Aphorisms) attributed to Ptolemy, which was originally composed in Arabic in the early tenth century by a certain Abu Jaffar Ahmad b. Yusuf (d. ca. 944) and later translated into Persian by different parties including Tusi; ${ }^{52}$

ii. Nasir al-Din al-Tusi and his Sïfașl;

iii. Kushyar ibn Labban and his Mujmal al-ușūl fi ahkām al-nujūm (Compendium of Astrological Principles, also named al-Mudkhalfi șinā'at aḥkàm al-nujūm); ;3

iv. Abu Rayhan al-Biruni and his Kitāb al-tafhìm liawā'il șinā'at al-tanjīm (Book of Instruction in the First Principles of the Art of Astrology);

v. Abu Ma'shar al-Balkhi (d. ca. 886), though his wellknown treatises, such as Kitāb al-mudkhal al-kabìr (General Introduction to Astrology), Kitāb al-milal wa'l-duwal (Book of Religions and Dynasties), and Kitāb al-ulūf (Book of Thousands), are not explicitly cited in the inventory; ${ }^{54}$

vi. Kifäyat al-ta' lìm fi șināà al-tanjüm (Sufficiency of Learning in the Art of Astrology) of Abu al-Mahamid b. Mas'ud al-Ghaznawi (fl. late twelfth century). .5

Numerous copies of these titles are catalogued in 'Atufi's inventory, and Tusi's Si fașl seems to have enjoyed the most popularity. There are, by our count, fourteen copies of this text (list of entries [55]/[153], [144], [145], [146], [147], [148], [149], [150], [151], [152], [154], [155], [156], [157]), including later commentaries, such as Khitabi-i Lahijani's lengthy Muwaddih al-rusūm fì 'ilm al-nujūm (The Expositor of the Notes in the Science of the Stars), which he presented to Mehmed II in December 1479. ${ }^{56}$ Next comes the corpus of Kitäb al-thamara with ten copies (list of entries [81], [82], [83], [84], [85], [86]/[159], $[87] /[160],[88] /[161],[89] /[162],[90] /[163])$ - two of which are cited in the history $(t \bar{a} r i \bar{k} h)$ section of the in- ventory-almost all in Persian. That most of the available Thamara copies in the palace library were written in Persian provides yet further proof for the ascendancy of the Persianate astral tradition within Ottoman circles. Ptolemy's major work in astrology, Tetrabiblos (Four Books of the Influence of the Stars), also seems to have been featured in the library, just as two separate copies of al-Battani's (d. 929-30) commentary are listed in the inventory (list of entries [11], [12]).

As for the books of Abu Ma'shar, the celebrated astrologer of Abbasid times, there are six titles recorded with explicit reference to his name (list of entries [1][6]). Yet, on the basis of the manuscript evidence with Bayezid's seal, it is safe to assume that some of the items listed in the inventory under different or generic titles might have also contained the works of Abu Ma'shar. For example, a majmū'a now preserved as SK, Ayasofya MS 3600 bears the almond-shaped seal of Bayezid II and hosts Abu Ma'shar's Kitāb tahāwiōl sinīal-mawālèd (Book of the Revolutions of the Years of Nativities), but the title assigned either by 'Atufi or one of his colleagues on fol. 1a of this compendium is Kitāb taqwìm al-adwiya fi altibb (The Book of the Table of Medicaments in [the science] of Medicine). ${ }^{57}$ In addition to the works of Tusi, (ps.-)Ptolemy, and Abu Ma'shar, the library inventory contains at least eight references to the Mujmal al-ușūl of Kushyar (list of entries [57]-[64]) and five references to the Kitāb al-tafhim of Biruni (list of entries [17]-[21]). Ghaznawi's Kifāya is also cited at least two times (list of entries [27]-[28]).

Before moving to the next section, we would like to make a few more notes regarding the general works on astrological principles. First, parallel to the dearth of references in the writings of early modern Ottoman $m u$ najjims to al-Qabisi (fl. second half of the tenth century), whose introduction to astrology (Kitāb al-mudkhal ilā șinā'at al-nujūm) became immensely popular in medieval and Renaissance Europe upon its translation into Latin from Arabic, the palace library has no volume explicitly related to him. ${ }^{58}$ Secondly, another popular (in the sense of the high number of surviving manuscripts) Persian astrological textbook, Lațāi if al-kalām fi a a kām al-a'wām (General Astrological Judgments) composed by Sayyid Munajjim (fl. first half of the fifteenth century), is only cited once in the inventory (list of entries 
[120]). ${ }^{59}$ Finally, we note that the celebrated astrologer from the Abbasid times, Masha'allah ibn Athari (d. ca. 815), is also not mentioned in the inventory, although the taqwims and other types of horoscopes produced in the early modern Ottoman world occasionally refer to him. ${ }^{60}$

\section{BIRTH HOROSCOPES AND OTHER GENRES}

$Z \ddot{y j}$ es and astrological textbooks were also put in use in other genres that calculate the horoscope at the hour of an event. The birth horoscope or natal chart, which was prepared primarily for the members of the ruling dynasty, is one such genre. The most famous example of the genre in the entire corpus of Islamicate astrology, due to its captivating illustrations, is the horoscope of the Timurid prince Mirza Iskandar b. 'Umar-Shaykh (d. 1415-16), composed around 1411 by Mahmud b. Yahya b. al-Hasan al-Kashi (d. after 1411), a close relative of Jamshid al-Kashi's. ${ }^{61}$ Not surprisingly, 'Atufi's inventory lists Mirza Iskandar's horoscope (list of entries [46]), which must have entered the Ottoman palace library along with other works on the science of the stars produced or circulated in the Timurid realm. ${ }^{62}$

This lavishly illuminated horoscope was not the only natal horoscope cited in the inventory, however. 'Atufi lists six birth horoscopes cast for members of the Ottoman dynasty. Three of these copies are horoscopes cast for Mehmed II, one of which was prepared by Khitabi-i Lahijani (list of entries: [52], [194]-[195]). Lahijani's text is stamped with Bayezid II's seal and tells us that a royal edition of it was penned in Istanbul in 1481 by Ghiyath al-Mujallid al-Isfahani. ${ }^{63}$ The other three horoscopes listed in the inventory are for Bayezid II ([197]), his son Mehmed (d. 1505) ([198]), and Prince Cem ([196]). To date, these three natal charts remain undiscovered, and thus we are not in a position to track the scholarly references in these horoscopes. ${ }^{64}$ However, similar to Iskandar's horoscope, the extant birth horoscopes of Mehmed II feature numerous references to Ptolemy, Kushyar, and Abu Ma'shar as authoritative sources. ${ }^{65}$

It is worth noting that, except for the natal chart of Prince Cem, all of the birth horoscopes are recorded in the inventory under the rubric of "pertaining to the stars" (min qibal al-nujūm). Another important group of titles classified with the same tag is the corpus on astronomical instruments and treatises on celestial observation. Notwithstanding several exceptions, we can speak here of a pattern observed by 'Atufi throughout the section of books on various celestial pursuits, which is also noted by Jamil Ragep and the McGill Team in their article in this volume. An obvious example of these exceptions is Tusi's popular treatise on the use of the astrolabe, Bìst ba a b fi'l-usturlāb (Twenty Chapters on Uses of the Astrolabe), referred to nine times in the inventory (list of entries [130]-[136], [26]/[137], [56]/[138]), along with its later commentaries, including that of Efezade (d. after 1495). ${ }^{66}$ This book is sometimes cataloged in the inventory under the rubric of min qibal al-nujūm and sometimes as fì ('ilm) al-nujūm. Likewise, the Kitāb althamara corpus is sometimes recorded with the tag $f i$ ( $\mathrm{ilm}$ ) al-nujüm and sometimes with aḥkām al-nujūm. In general, however, 'Atufi seems to follow a discernible blueprint, cataloging all the zijjes and many of the textbooks of an astrological nature under the tags ilm alnujūm or nujūm, and the majority of treatises on instruments of observation under min qibal al-nujūm.

One important aspect of the min qibal al-nujüm subsection is that it also contains very rare examples of relevant works in Turkish. ${ }^{67}$ There are references to at least three copies of Turkish translations of the Mamluk astronomer al-Khalili's (d. ca. 1365) timekeeping tables and astronomical instruments (list of entries [48]/[98], [49]/[99], [50]/[100]), completed by Muhammad b. Katib Sinan al-Qunawi (d. 1524), who worked in the early sixteenth century as the muwaqqit (timekeeper) in various mosque complexes in Edirne and Istanbul. ${ }^{68}$

Titles on specific branches of astrology—such as interrogations or horary astrology (masāìl), which intend to compute and interpret a horoscope for the exact time the client asks questions to the munajjim, and elections (ikhtiyārāt), which is concerned with the choice of an auspicious moment for doing or avoiding a particular activity-are sometimes categorized in the inventory under the rubric of 'ilm al-nujūm and sometimes as ahkām al-nujūm. One should highlight here the Kitāb al-masā'il of Ya'qub b. 'Ali al-Qasrani (fl. ninth century). Not much is known about him, although later sources, including Fakhr al-Din al-Razi (d. 1210), cite Qasrani 
among other astrological authorities from the early Abbasid period, including Abu Ma'shar, 'Umar b. alFarrukhan al-Tabari (d. 815-16), and Sahl b. Bishr (fl. $821-50) .{ }^{69}$ His compilation on horary astrology, which treats a wide array of questions and cases by interpreting the astrological significance of the time when a particular question was posed to him, seems to have been popular in the Ottoman realm. Not only does the palace library inventory cite four copies (list of entries [91][94]), but Mirim Çelebi, in his treatise on horary astrology, also recommends that his readers consult Qasrani's compilation for further reading on the topic. ${ }^{70}$ In addition to Qasrani, Fakhr al-Din al-Razi's influential work on electional astrology, al-Ikhtiyārāt al-'alä'iyya fíahkām al-samāwiyya (On the Selection of Propitious Times for Various Acts and Affairs), of which al-Razi himself prepared both Arabic and Persian editions, was represented by at least four copies in the palace library according to 'Atufi's inventory (list of entries [114]-[117]). ${ }^{71}$ Another important work attributed to al-Razi, al-Sirr al-maktūm (The Hidden Secret), a treatise on celestial magic, is also listed in the inventory at least six times $(308\{15\},\{16\}$, $\{16-17\},\{17-18\} ; 309\{1-2\},\{2-3\})$, albeit it does not appear in this particular section, where titles related to astral and mathematical sciences are enumerated, but rather in the section on natural and occult sciences immediately preceding the quadrivium: Tafșil kutub 'ilm al-ta'bìr wa-kutub 'ilm al-firāsa wa-kutub al-ilm alkimiya' wa-kutub 'ilm al-ahjār wa-kutub al-raml wa-kutub al-fāl wa-kutub 'ilm al-nayrinjāt wa-kutub al-țilsimāt wa-kutub al-simiya $\bar{a}^{\prime}$ wa-kutub al-'azā'im wa-kutub 'ilm al-jafr wa-kutub al-șinā'āt al-'ajība wa-kutub al-hiyalwakutub al-sihr (The Section on Dream Interpretation/ Oneiromancy, Physiognomy, Alchemy, Gemology, Geomancy, Divination, Terrestrial Magic, Celestial Magic or Talismans, Letter Magic, Jinn Magic, Letter Divination, Mechanics and Wondrous Devices, Magic).

\section{'ATUFI'S RECLASSIFICATION OF THE ASTRAL AND OCCULT SCIENCES}

By locating al-Razi's al-Sirr al-maktūm among titles in natural and occult sciences while listing the same author's work on electional astrology, al-Ikhtiyārāt al-'alā'iyya, under mathematical sciences, 'Atufi clearly deviates from the more canonical Avicennan tradition, which typically discusses ahkām al-nujūm under the rubric of natural sciences (țabíciyyāt) along with dream interpretation, physiognomy, geomancy, alchemy, and various magical practices. In order to understand why 'Atufi introduced the section on natural and occult sciences immediately before the quadrivium and why he listed all the strictly astrological titles in the latter section, it is necessary to revisit relevant debates in the medieval Islamicate taxonomies of sciences and observe the impact of Persianate encyclopedism, specifically of Razi's Jāmi' al-'ulūm (Compendium of Sciences, also known as Hadā'iq al-anwār fi haquā'iq al-asrār or Kitāb-i sittin $\bar{\imath}$ ) on the reclassification of astrology under the rubric of mathematical sciences.

Given the great diversity of examples written in different languages, which adopt various methods of classification, it is quite difficult, and indeed misleading, to speak of a single, easy-to-define Islamicate taxonomy of science. The rationale upon which knowledge was hierarchically categorized by various authors varied greatly. Besides such established conventions as dividing knowledge into categories of transmitted ('al-ulūm al-naqliyya) and rational sciences (al-'ulūm al-'aqliyya), or religious sciences versus the sciences of the ancients ('ulūm al-awā'il), branches of knowledge were also grouped, as in the case of al-Ghazali (d.1111), into rather subjective categories of praiseworthy, blameworthy, and permissible sciences. Another method, also largely favored by later Ottoman classifiers of knowledge, was the Aristotelian tradition, which found its way into the medieval Islamicate context especially through the works of Ibn Sina (d. 1037) and partially through those of al-Farabi (d. 950). ${ }^{72}$ Accordingly, theoretical philosophy (al-hikma al-nazariyya) is divided into three hierarchical categories, each corresponding to one of the realms of the tripartite scheme of the cosmos. The lowest (asfal), terrestrial world, i.e., the world of generation and corruption, is the main concern of natural and occult sciences, which essentially deal with the sub-lunar domain that is subject to physical change. The study of the middle (awsat ), unchanging celestial region requires unwavering mathematical proofs and geometrical demonstrations, whereas the highest $\left(a^{\imath} l \bar{a}\right)$ sphere beyond 
the celestial orbs concerns metaphysics and theological sciences. ${ }^{73}$

Within this mainstream Avicennan taxonomy of sciences, astrology ( 'ilm ahkām al-nujūm) was detached from the mathematical investigation of heavenly objects ('ilm al-hay'a) and classified exclusively as a natural science (al-hikma al-țabīinya) along with medicine, geomancy, alchemy, and other divinatory practices and arts of magic. The epistemological distinction between the two, however, was neither revolutionary nor entirely unambiguous. For example, Ptolemy covered astronomy in his Almagest, while devoting Tetrabiblos to what he defined as "prognostication through astronomy" ( $\tau \dot{0}$

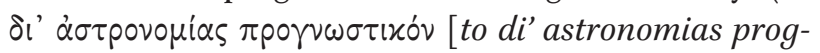
nostikon]); he acknowledged that astronomy was intended for the investigation of the movements of celestial bodies and the planetary aspects, whereas the latter deliberated the corollary changes appearing in the terrestrial realm.

Discussions on the classification of astrology in the medieval Islamicate intellectual realm were marked by similar controversies and inconsistencies that were sometimes apparent even in the same work of a single author. Such controversy was mostly due to the subject, methods, and objectives of this science, which, as a contentious discipline, was categorically considered (i) among the sciences of the ancients, which a great many ulema in the Islamic Middle period often took with a grain of salt; (ii) dependent upon the unwavering mathematical knowledge of the heavens but applied to understand the ever-changing physical nature of the sub-lunar world; and iii) susceptible to being interpreted as a quest threatening to undermine the belief in God's omnipotence. ${ }^{74}$

Taşköprizade's treatment of the astral sciences is a perfect example of such complications and inconsistencies. Following the Avicennan model that he largely inherited from the Mamluk encyclopedist Ibn al-Akfani (d. 1348), Taşköprizade makes a clear distinction between 'ilm al-hay'a and 'ilm ahkām al-nujūm, classifying the former in the mathematical sciences (al-'ulüm alriyā diyya) and the latter in the natural sciences (al-'ulüm al-țabīiyya). At times, he uses 'ilm al-nujūm and 'ilm alhay'a interchangeably and further emphasizes the distinction between 'ilm al-nujūm and ahkām al-nujūm by saying that the former relies upon mathematics and calculation (hisāb), whereas the latter aims at determining the physical influences in nature. ${ }^{75}$ Nevertheless, in his section on 'ilm al-hay'a under the general category of mathematical sciences, Taşköprizade lists, among others, 'ilm al-zìjāt wa'l-taqāwim (the science of astronomical tables and almanacs), 'ilm al-qirānāt (the science of conjunctions), 'ilm al-ālāt al-rașadiyya (the science of the instruments of celestial observation), and ilm almalähim (the science of weather prognostications), all of which, he explicitly maintains, have strong astrological implications. ${ }^{76}$

Unlike Taşköprizade and subsequent generations of well-known Ottoman encyclopedists, including Nevi Efendi and Katib Çelebi, 'Atufi emphatically records astrological titles under the rubric of mathematical sciences, right after his section on natural and occult scientific practices. In this regard, he seems to have preferred non-Avicennan models, such as al-Razi's classification in his Persian encyclopedic work, where ahkām al-nujūm is deliberately detached from natural and occult sciences and placed right next to 'ilm al-hay'a under the mathematical sciences. ${ }^{77}$ Razi's classification exerted an influence on several other examples of the taxonomy of science genre in Persian and also found an enthusiastic reception in the fifteenth-century Ottoman world, particularly within the Fenari circle. ${ }^{78}$ It is worth mentioning here that 'Atufi's organization of this section (and others) also accords closely with the schematic classification of the sciences by 'Abd al-Rahman al-Bistami (d. 1454), a prominent protégé of both Molla Fenari and Sultan Murad II (r. 1421-44; 1446-51) whose works (some in autograph) entered the palace library. ${ }^{79} \mathrm{Al}$-Bistami's "tree of knowledge," which is found in his autobiographical bibliography, titled Durrat tāj alrasā'il (Pearl in the Crown of Tractates), firmly attaches astranūmiya (اسطرنوميا) to the mathematical sciences, while at the same time expressing his commitment to "Greek learning" by using Greek terminology whenever possible. ${ }^{80}$ Thus, 'Atufi's deviation from the more canonical, Avicennan tradition is certainly not exceptional and serves as another reminder to modern scholars that the Ottoman taxonomy of science is not singularly represented by Taşköprizade or Katib Çelebi. 
A detailed discussion of the titles related to natural and occult sciences in 'Atuf's inventory is beyond the scope of this article. Yet we should note that the occult section of the palace library shows patterns similar to the collection of books on celestial knowledge, insofar as it incorporates works produced in the post-Mongol Persianate world as well as examples from the GraecoArabic tradition. ${ }^{81}$ For instance, among the no less than twenty-four copies of dream interpretation manuals, six are Hubaysh b. Ibrahim b. Muhammad Tiflisi's (d. ca. 1203-4) Kāmil al-taçōr (Compendium of Dream Interpretation), which the author composed in Persian and dedicated to the Rum Seljuq ruler Qilij Arslan II (r.115692) (302 $\{16-17\},\{17\},\{18\},\{18\},\{19\},\{19\}) .{ }^{82}$ Of the sixteen treatises on physiognomy, the text attributed to Polemon of Laodicea (ca. 88-144 CE), Kitāb Falīmūn or Aflimūn al-Hakìm, stands out with at least four copies (304 $\{11\},\{12\},\{12-13\},\{15\})$, next to the physiognomical works of Fakhr al-Din al-Razi (304 $\{19\}-305\{1\})$ and Muhammad Nurbakhsh (d. 1462) (304 \{18\}). ${ }^{83}$

\section{CONCLUSION}

Around the time the library inventory was compiled, one of the aspirant munajiims approached Bayezid II in an anonymous Persian petition, asking for access to some of the items in the imperial treasury (khizāne). ${ }^{84}$ The requested items included a complete astrolabe (usțulāb-i tām), the works Zīj-i Ulugh Beg and Kitāb-i Majisțī, and the horoscope of the sultan (țālici $i$ hażret-i 'àlem-penāhì) along with those of his sons, Korkud and Ahmed. The anonymous munajjim also reassures the sultan that if the horoscopes are not currently available, he could produce (new) ones for each, so long as he is informed of the exact birthdates of the sultan and the princes.

Except for the horoscopes of Princes Korkud and Ahmed, which are not listed in 'Atufi's inventory, the items that the anonymous munajjim requested accord well with the holdings of the imperial treasury, which, in addition to the books in question, also housed a rich collection of astronomical instruments during Bayezid II's reign. ${ }^{85}$ This raises the questions of whether 'Atufi's inventory was accessible to other members of the palace at the time and whether minor updates were made to the already finished and embellished inventory. Of course, the anonymous aspirant munajjim might have simply heard about these items at the treasury from his colleagues. No matter what the accessibility of 'Atufi's library inventory may have been, the munajjim's petition as well as Bayezid's own reading preferences unequivocally show that the titles on practical astral sciences, particularly those related to the post-thirteenth-century astral lore of the Persianate East, were certainly in use whenever the need arose.

\section{NOTES}

Authors' note: The references to inventory items in bracketed numbers throughout refer to those in our list of entries, which follows this essay.

1. The manuscript was published as a facsimile in 'Abd al-Raḥmān ibn 'Umar al-Ṣūfĩ and Nașīr al-Dīn Muhammad b. Muḥammad al-Ṭūsī, Tarjama-i șuvar al-kavākib (Tehran: Bunyād-i Farhang-i Īrān, 1348/1969).

2. MS Török F. 59, $317\{3-4\}$.

3. For the story of the two hundred people accompanying 'Ali al-Qushji during his journey to Istanbul, see Nişāncızāde Muhyyiddīn Meḥmed's (d. 1621) Mir'atü'l-kā’ināt, cited in Süheyl Ünver, Ali Kuşci Hayatıve Eserleri (Istanbul: Kenan Matbaası, 1948), 17.

4. The term is borrowed from İhsan Fazlıoğlu. See his "The Samarqand Mathematical-Astronomical School," Journal for the History of Arabic Science 4, no. 1-2 (2008): 3-68.

5. George Saliba, "Astronomy and Astrology in Medieval Arabic Thought," in Les doctrines de la science le l'antiquité à l'âge classique, ed. Roshdi Rashed and Joël Biard (Leuven, 1999), 131-64; George Saliba, "Islamic Astronomy in Context: Attacks on Astrology and the Rise of the Hay'a Tradition," Bulletin of the Royal Institute for Inter-Faith Studies 4, no. 1 (2002): 25-46. For a critical overview of the categorization of the astral sciences in medieval Islamic sources, see A. Tunç Şen, "Astrology in the Service of the Empire: Knowledge, Prognostication, and Politics at the Ottoman Court, 1450s-1550s" (PhD diss., University of Chicago, 2016), 59-79. Also see the essay in this volume by Jamil Ragep and the McGill Team.

6. $E_{3}$, s.v. "Astronomy," by Jamil Ragep. Although Jamil Ragep does not specifically refer to ahkām in his discussion, relevant sources often mention $a h k a \bar{m} m$ within the all-encompassing science of the stars. See n 8 below.

7. Modern literature on $z \bar{j}$ jes has barely highlighted the astrological significance of these texts, though scholars are definitely aware of the astrological components in $z \bar{j} j \mathrm{jes}$. See Edward S. Kennedy, "A Survey of Islamic Astronomical Tables," Transactions of the American Philosophical Soci- 
ety, n.s., 46, no. 2 (1956): 123-77; EI2, "Zidj," by F. C. De Blois, D. A. King, and J. Samsó; David A. King, Julio Samsó, and Bernard R. Goldstein, "Astronomical Handbooks and Tables from the Islamic World (750-1900): An Interim Report," Suhayl: International Journal for the History of the Exact and Natural Sciences in Islamic Civilisation 2 (2001): 9-105; Benno van Dalen, Islamic Astronomical Tables: Mathematical Analysis and Historical Investigation (London: Ashgate, 2014).

8. Al-Bīrūin̄, The Book of Instruction in the Elements of the Art of Astrology, ed. and trans. Ramsay Wright (London: Luzac \& Co., 1934), 1; Ṭūsī, Zìj-i ìlkhānī, Biblioteca Medicea Laurenziana MS Or. 24, 2b. Rukn al-Din Amuli, a munajjim active in the Iranian world in the first half of the fifteenth century who composed his own $z \vec{i}$ and trained a number of students including Khitabi-i Lahijani, also wrote a treatise on the use of the astrolabe, Panjāh bāb-i sulțāni (Fifty Chapters). In this treatise, he states that the ultimate fruit and reward (thamara) of the mathematical sciences ('ilm- $i$ hay'a, handasa va hisāb) is the science of the judgments [of the stars] ('ilm-i ahkām) and the knowledge of [prayer] time[s] (ma'rifat-i avqāt), and that this builds upon the knowledge gleaned from the observation of the [fixed] stars (ma'rifat-i rașad-i sitāragān), the calculation of the [mean] motions of planets (istikhräj-i taqvim-i kavākib), and the designation of the ascendants of the hours (tavālic $-i s \bar{a} c \bar{a} t)$. See Harvard MS Persian 33, 2a.

9. Aydın Sayll, The Observatory in Islam and Its Place in the General History of the Observatory (Ankara: TTK, 196o).

10. The discrepancy in numbers is even more significant considering that some of the hay'a books were taught at certain madrasas, and thus more copies of these texts must have been in circulation. See Cevat İzgi, Osmanlı Medreselerinde İlim, 2 vols. (Istanbul: İz, 1997), 1:361-412.

11. For a general overview of Ottoman scientific activity before the sixteenth century, see TDVIA, s.v. "Osmanlılar (İlim ve Kültür. 1. Düşünce Hayatı ve Bilim. Kaynaklar),” by İhsan Fazlığlu.

12. For the early fifteenth-century Turkish translation of $S \bar{\iota}$ faṣl, see Aḥmed-i Dācī, Muhtasar fi ilm el-tencim ve marifet el-takvim (Risale-i si fasl), ed. T. N. Gencan and M. Dizer (Istanbul: Boğaziçi Üniversitesi Kandilli Rasathanesi, 1984).

13. 'Abdulwajid b. Muhammad was born in Khurasan and came to the lands of Rüm in the later fourteenth century. In addition to his treatise on the uses of astrolabe, he also penned a commentary on Tusi's Si fașl. See Osmanlı Astronomi Literatürü Tarihi $=$ History of Astronomy Literature during the Ottoman Period, 2 vols. (Istanbul: İslâm Tarih, Sanat ve Kültür Araştırma Merkezi, 1997), 1:22-24. See also İhsan Fazlıoğlu, "İthaftan Enmûzec'e Fetih'ten önce Osmanlı Ülkesi'nde Matematik Bilimler," in Uluslararası Molla Fenârî Sempozyumu (4-6 Aralık 2009 Bursa): bildiriler = International Symposium on Molla Fanârî (4-6 December 2009 Bursa): Proceedings, ed. Tevfik Yücedoğru et al. (Bursa: Bursa Büyükşehir Belediyesi, 2010), 131-63; Jamil Ragep, "Astronomy in the Fanārī-Circle: The Critical Background for Qādīzāde al-Rūmī and the Samarqand School," in Yücedoğru et al., Uluslararası Molla Fenârî Sempozyumu, $165^{-76}$.

14. TDVIA, s.v. "Kadızade-i Rumi," by İhsan Fazlığlu.

15. 'Abdurrahman Munajjim, Jawhar hifz al-sihhat fí al-tibb, SK, Ayasofya MS 3635, 2 b (also listed in the inventory: $166\{15\}$ ). His first instructor, Mevlana Kuçek, was listed in the palace payroll of 1478 as the only royal munajjim at the time under the rubric of müteferrika. See Ahmed Refik (Altınay), "Fatih Devrine ait Vesikalar," Tarih-i Osmani Encümeni Mecmuası 8-11, nos. 49-62 (1335/1919): 1-58. Mevlana Kuçek's zij, which was presented to Bayezid II when the latter was still in his gubernatorial seat in Amasya, is recorded in the inventory (list of entries [69]).

16. Idrīs-i Bidlīsī, Hasht Bahisht, SK, Esad Efendi MS 2198, 33b34a, also quoted in Tofigh Heiderzaideh, "Ali Kuşçu'nun Astronomi Eserleri” (master's thesis, Istanbul University, 1997), 15 .

17. Robert Westman's observation regarding the political instrumentality of astronomical/astrological patronage and the active involvement of the patron in learning the science itself in the early modern European context also holds true for the Islamicate realm. See Robert Westman, "The Astronomer's Role in the Sixteenth Century: A Preliminary Survey," History of Science 18, no. 2 (1980): 105-47.

18. For an overview of the available sources on al-Qushji's move to the Ottoman capital and his tenure there, see Heiderzaideh, “Ali Kuşçu'nun Astronomi Eserleri,” 13-17.

19. This is discussed in more detail in A. Tunç Şen, "Reading the Stars at the Ottoman Court: Bayezid II (r. 886/1481-918/ 1512 ) and His Celestial Interests," Arabica 64, no. 3-4 (2017): 557-6o8.

20. TSMA, E. 6172.

21. Țashkoprīzāde, al-Shaqā’iq al-nu'māniyya fí ulamā'al-dawlat al-'uthmāniyya (Beirut: Dār al-kitāb al-'arabī, 1395/1975), 198.

22. The autograph copy is available at SK, Ayasofya MS 2697 . Mirim says in this copy (2a) that he was in the service of Mawlana 'Ata'ullah, another émigré scholar from Kirman, while 'Ata'ullah was working on the commentary of the Ulugh Beg tables, probably in Istanbul. Surprisingly, this detail about 'Ata'ullah is not included in other available copies of the commentary.

23. List of entries [74]/[185]. So far as it is known, the supplication sallamahu was used for authors who were alive at the time.

24. Tashkoprīzāde, $249-50$. While the familial ties between Mirim Çelebi and Qutb al-Din are not certain, they appear to be the sons of the same father based on their nisbas given by Taşköprizade. Qutb al-Din's supercommentary on al-Samarqandi's Propositions for the Foundation is also listed in the inventory (list of entries $[555] /[556] /[565]$ ).

25. The in'āmāt defteri (Atatürk Kitaplığı, Muallim Cevdet O. 71) lists all the gifts and payments Mirim and his wife received from the sultan between 1503 and 1512. Another sign of Mirim's closeness to Bayezid II is that during the 
pro-Selim rebellions in Istanbul in 1511, Mirim's house was targeted along with the mansions of other important individuals who were close to the sultan. See Çağatay Uluçay, "Yavuz Sultan Selim Nasıl Padişah Oldu II," IÜEFT Dergisi, 7-10 (1954): 120-21.

26. SK, Ayasofya MS 2474. This copy should be [145]/[298]/ [438] in the list of entries.

27. Bursa Türk ve İslam Eserleri Müzesi, MS 11. We would like to thank Zeren Tanındı for this information about the manuscript.

28. TSMK, A. 3328. Either [421] or [422] in the list of entries should be the copy in question.

29. TSMK, A. 3317. [394] in the list of entries might the copy in question. For Tadhkira fì 'ilm al-hay'a, see Nașir al-Dìn al-Ṭūsìs Memoir on Astronomy = al-Tadhkirafí 'ilm al-hay'a, ed. Jamil Ragep, 2 vols. (New York: Springer-Verlag, 1993).

30. SK, Ayasofya MS 2702. [9] and [10] in the list of entries should be the title in question.

31. TSMK, A. 2128. See Ikhwān al-Șafā', On Astronomia: An Arabic Critical Edition and English Translation of Epistle 3, ed. Jamil Ragep and Taro Mimura (Oxford: Oxford University Press, 2015).

32. SK, Ayasofya MS 2618. [228] in the list of entries is the title in question.

33. SK, Ayasofya MS 2711. [25] in the list of entries is the title in question.

34. TSMK, A. 3343, listed as [67] or [68]. For a facsimile edition of the text, see Traité des instruments astronomiques des Arabes composé au treizième siècle par Abū'l-Hasan 'Alī al-Marrākūshī (VII-XIII s.) intitulé Jāmi` al-mabādi' wa-lghāyāt, 2 vols., (Frankfurt am Main : Institut für Geschichte der Arabisch-Islamischen Wissenschaften, 1998).

35. SK, Ayasofya MS 2432. This volume should be the one listed as [109].

36. One entry in 'Atufi's inventory could indeed be interpreted as a taqwìm. The item listed as [239] contains Kitābjadāwil al-tawārīkh wa-al-nujūm (The Book of Chronology Tables and Star Charts). However, we should note that none of the extant taqwim manuscripts with the seal of Bayezid II bears such a title among its inscriptions.

37. For more on Khitabi, see Şen, "Reading the Stars," esp. 577-82. Four different works of Khitabi in five copies are listed in the inventory. See the list of entries at the end of our essay: [51]-[55].

38. SK, Esad Efendi MS 205, 2 b.

39. Kātib Çelebi, Takvîmü't-Tevarih İndeksli Tıpkı Basım (Ankara: Türk Tarih Kurumu, 2009), 4a.

40. For more information on the taqwim genre, see Şen, "Astrology in the Service of the Empire," 237-304; EI2, s.v. "Takwīm," by M. Hofelich and D. M. Varisco; Hofelich, "The Making of Taqvims in Iran," in La science dans le monde Iranien à l'époque islamique, ed. Živa Vesel et al. (Tehran: Institut Français de Recherche en Iran, 1998), 49-51.

41. Tâlic is the point of the Zodiac rising above the horizon at the moment of nativity or any other event on which the horoscope is being cast. See also EI2, s.v. "al-Ṭālic," by David
King and Toufic Fahd. The concept gradually transformed in vernacular Turkish into țălih, denoting fortune and luck. It is difficult to ascertain when exactly this transformation occurred, yet as Meniński's Thesaurus Linguarum Orientalum reveals, țălih was in use as early as the first half of the seventeenth century.

42. Ikhtiyārät (Elections, or Choices) is a major division of astrology by which the munajjim identifies the auspicious time to carry out an activity. $E I_{3}$, s.v. "Astrology," by Charles Burnett.

43. In stressing the urgency of the rulers' support, munaijims often referred to the financial difficulty of possessing sizeable and reliable astronomical instruments without assistance from the sovereigns. See, for instance, Rukn al-Din Amuli's Panjāh bāb-i sulțānī or 'Ali-Shah Bukhari's Kitāb athmār wa-ashjār fi al-nujūm (The Book of Fruits and Trees), the latter of which is cited in 'Atufi's inventory as $[22] /[165]$ (see list of entries).

44. For the $z \bar{i} j$ genre, see $n 7$.

45. See Fateme Savadi and Sajjad Nikfahm-Khubravan, "Harakat-i wasaț-i kawākib dar Zīj-i ìlkhānī wa naqd-hā-yi wārid bar ān" [The mean motion of the planets in $Z \bar{i} j-i$

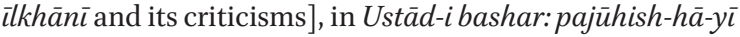
dar zindigī, rūzigār, falsafa wa 'ilm-i Khwāja Nașìr al-Dīn Țüsi [The teacher of humankind: essays on the life, times, philosophy, and scientific achievements of Khwāja Nașīr al-Dīn Tūūin], ed. H. Masoumi Hamedani and M. Javad Anvari (Tehran: Mīrās̄-i Maktūb, 1391/2012), 363-470. For Wabkanawi, see Mohammad Mozaffari, "Wābkanawìs Prediction and Calculations of the Annual Solar Eclipse of 30 January 1283," Historia Mathematica 40 (2013): 235-61; Jamil Ragep, "New Light on Shams: The Islamic Side of $\sum \dot{\alpha} \mu \psi$

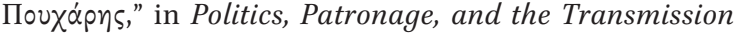
of Knowledge in $13^{\text {th }}-15^{\text {th }}$ Century Tabriz, ed. Judith Pfeiffer (Leiden: Brill, 2013), 166-80.

46. For more details, see Appendix C in Şen's dissertation.

47. For a brief biography of Taqi al-Din, see İhsan Fazlığlu, "Taqī al-Dīn," in The Biographical Encyclopedia of Astronomers, ed. Thomas Hockey et al. (New York: Springer, 2007), $1122-23$.

48. We should also note, however, that some of the "verified" Ilkhanid tables cited explicitly by contemporary Ottoman munajjims in their taqwims might be referring to different, later editions and commentaries of the Ilkhanid tables, instead of to that of Wabkanawi. Mü'eyyedzade (d. 1516) seems to have had a copy of Wabkanawi's Verified Tables that he purchased in Ladik in 1477. See SK, Ayasofya MS 2694. This copy does not have the idiosyncratic almondshaped seal of Bayezid II.

49. For the contents and astrological significance of this $z \bar{i}$, see Robert Morrison, Islam and Science: The Intellectual Career of Nizām al-Dīn al-Nīsābūrì (New York: Routledge, 2007), esp. $63-70$.

50. TSMK, R. 1713. The copy has brief notes including an ownership statement on the title page, revealing that the Ottoman scholar-bureaucrat Mü'eyyedzade (d. 1516) used the book for his own calculations of ascendants. 
51. The McGill Team notes that the description of this title is strikingly similar to the introduction to Athir al-Din alAbhari's (d. ca. 1265) al-Zïj al-shāmil (The Comprehensive Tables).

52. Richard Lemay, "Origin and Success of the Kitāb Thamara of Abū Ja'far Aḥmad ibn Yūsuf ibn Ibrāhīm," in Proceedings of the First International Symposium for the History of Arabic Science: April 5-12, 1976, ed. Ahmad Y. al-Hassan et al. (Aleppo: University of Aleppo, 1978), 91-107. For Tusi's Persian translation of al-Thamara, see Sharh-i Samarah-i Bațlamyūs dar ạ̣kām-i nujūm, ed. Khalīl Akhavān Zanjānī (Tehran: Āyīnah-i Mīrās, 1999).

53. Kūshyār ibn Labbān's Introduction to Astrology, ed. Michio Yano (Tokyo: Tokyo University of Foreign Studies, 1997).

54. For Abu Ma'shar's biography and works, see David Pingree, "Abū Ma'shar al-Balkhī, Ja'far ibn Muhammad," in Dictionary of Scientific Biography, 1:32-39.

55. Not much is known about the life of Ghaznawi. For the copies of the text, see C. A. Storey, Persian Literature: A Bio-Bibliographical Survey, 5 vols. (London: Luzac, 1927), 2:46-47.

56. SK, Ayasofya MS 2709. This copy should be [55]/[153] in our list of entries.

57. This manuscript should be the one listed in MS Török F. 59, $169\{2\}$.

58. See al-Qabīṣi (Alcabitius), The Introduction to Astrology: Editions of the Arabic and Latin Texts and an English Translation, ed. Charles Burnett, Keiji Yamamoto, and Michio Yana (London: Warburg Institute, 2004); Margaret Gaida, "Encounters with Alcabitius: Reading Arabic Astrology in Premodern Europe" (PhD diss., University of Oklahoma, 2017).

59. The manuscript libraries in Turkey and major European countries host no less than ten extant manuscripts of the work. There should be even more surviving copies in Iran.

6o. For his life and works, see EI2, s.v. "Māshā' Allāh b. Atharī or b. Sāriya," by Julio Samsó.

61. The horoscope of Iskandar has yet to be published as a critical edition, but several studies have already explored different aspects of it. For the astrological and astronomical content of the text, see especially L. Elwell-Sutton, "A Royal Tīmurid Nativity Book," in Logos Islamikos, in Honorem Georgii Michaelis Wickens, ed. Roger Savory and Dionisius Albertus Agius (Toronto: Pontifical Institute of Medieval Studies, 1984), 119-36.

62. [46] in our list of entries.

63. TSMK, YY 830.

64. The earliest, and apparently the only, surviving copy of Bayezid II's horoscope comes from the second half of the eighteenth century. See Kandilli MS 396.

65. TSMK, YY 830 and Beyazit Library MS 4619, passim.

66. For Efezade's commentary, see SK, Ayasofya MS 2641 (list of entries [26]/[137]).

67. There are at least two other texts in the inventory related to astral sciences that are written in Turkish. The first is a book on meteorological/astrological prognostications,
Kitāb al-Malhama al-Turkiyya, cited (list of entries [209]) in the section on ilm al-figh. The second is a book on the astrological judgments of solar and lunar eclipses, Risāla fi ahkām al-khusūf wa-al-kusūf bi-al-Turkiyya al-manzūma, recorded (list of entries [257]) in the Turkish poetry section, simply because it is in verse.

68. İhsan Fazlığlu, "Qunawī: Muḥammad ibn al-Kātib Sīnān," in The Biographical Encyclopedia of Astronomers, ed. Thomas Hockey et al. (New York: Springer, 2007), 945-46.

69. TSMK, R. 1705, 2a.

70. Mirim Çelebi's work circulated under different titles, such

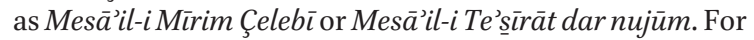
his reference to Qasrani, see SK, Bağdatlı Vehbi MS 2005, $38 \mathrm{~b}$.

71. This important work has also yet to be published. See Storey, Persian Literature, 2:49.

72. Al-Fārābī, Ihṣă’ al-'ulūm (Beirut: Dār wa-maktabat al-Hilāl, 1996); Ibn Sīnā, Tis' rasā’il fi-l-hikma wa-l-țabíciyyāt (Cairo: Mațba'at Hindīyah, 1908). Al-Fārābī also treats the question of the epistemology and efficacy of astrology in a separate treatise, Risāla fi mà yașihhu wa-mā là yașihhu min ahkām al-nujūm. See "Bemerkunden des Abū Nașr über die Richtigen und Falschen astronomischen entscheide," in Al-Fārābì's Philosophische Abhandlungen, ed. Fr. Dieterici (Leiden: Brill, 1892).

73. Fazlıoğlu, "Samarqand Mathematical-Astronomical School," 13 .

74. For a more detailed discussion, see Şen, "Astrology in the Service of the Empire," 59-79.

75. Ṭāshkoprīzāde, Miftāh al-sa āda wa misbāh al-siyāda, vol. 1 (Hyderabad: Dā'irat al-Ma'ārif al-'Uthmāniyā, 1977), 313.

76. In Taşköprizade's elaboration of 'ilm al-qirānāt (the science of conjunctions), for instance, he goes on to say that, as many astral experts state, there is a correlation between the occurrence of grand conjunctions and the shift of dynasties or the emergence of world conquerors such as Alexander the Great, Chingiz Khan, or Timur (ibid., 359-6o).

77. Fakhr al-dīn al-Rāzī, Jāmi`al-'ulūm, ed. Muhammad Húsayn Tasbīḥ̄ (Tehran: Kitābkhāna-i Asadī, 1346/1967-68). For the importance of Razi's encyclopedia with special regard to the discussion of several occult sciences, including astrology as one of the mathematical sciences, see Matthew Melvin-Koushki, "Powers of One: The Mathematicalization of the Occult Sciences in the High Persianate Tradition," Intellectual History of the Islamicate World 5, no. 1 (2017):127-99. We should note, however, that unlike Razi, 'Atufi lists geomancy and jinn magic under natural occult sciences.

78. For the medieval Persian taxonomy of the sciences tradition, see Živa Vesel, Les encyclopédies persanes: essai de typologie et de classification des sciences (Paris: Editions Recherche sur les civilisations, 1986). For Muhammad Shah Fanari's encyclopedic work, which relies heavily upon Razi's text, see Kemal Faruk Molla, "Mehmed Şah Fenâri'nin Enmûzecu'l-Ulûm adlı eserine göre Fetih öncesi dönemde Osmanlılar'da ilim anlayışı ve ilim tasnifi," Dîvân İlmî Araştırmalar 18, no. 1 (2005): 245-73. 
79. For two examples of mss. bearing the seal of Bayezid II, see TSMK, A. 3167, a corrected presentation copy of Durrat al-funūn fi rū'yat qurrat al-'uyūn (On Seeing the Prophet in Dream State), begun in 832/1428-29 and completed Friday, 10 Sha'ban 843/January 16, 1440; and TSMK, A. 1597, an autograph of the important Nażm al-sulūk fì musāmarat al-mulük (Ordering of the Paths for the Accompaniment of Rulers) completed 24 Dhu'l-Qa'da 834/August 3, 1431 (where the "tree of knowledge" is reproduced on fol. 53a). The former manuscript should be the one listed in MS Török F. 59, 303 \{12-13\}: Kitāb durrat al-funūn fì ruyat qurrat al-'uyūn fi al-ta'bìr. The latter should be the one listed in MS Török F. 59, 194 \{14-15\}: Kitāb nazm al-sulūkfi musāmarat al-mulūkfí al-tawārīkh al-gharība.

8o. SK, Nuruosmaniye MS 4905, $20 a$.

81. For a brief discussion of the alchemical treatises in 'Atufi's inventory, see Tuna Artun, "Bâyezîd-i Kîmyầî: Osmanlı Kimya Metinlerinde Sultan II. Bayezid," Journal of Turkish Studies/Türklük Bilgisi Araştırmaları 39 (2013): 181-86.

82. Encyclopaedia Iranica, s.v. "Hobayš b. Ebrāhim b. Moḥammad b. Teflisi," by Tahsin Yazıcı. Yazıcı maintains that at least three different Turkish translations of this text were produced during the reigns of Murad II, Selim I, and Süleyman I.

83. For the Arabic renditions of Polemon's text, see Antonella Ghersetti and Simon Swain, "Polemon's Physiognomy in the Arabic Tradition," in Seeing the Face, Seeing the Soul: Polemon's Physiognomy from Classical Antiquity to Medieval Islam, ed. Simon Swain (Oxford: Oxford University Press, 2007), 309-25.

84. TSMA, E. $10159 / 6$.

85. In an individual register drafted in 10 Sha'ban 910 (January 16,1505$)$ by Mevlana Kasım Çelebi and Pir Mehemmed Çelebi for the purpose of recording the holdings of the imperial inner treasury (khizāne-i 'àmire-i enderūnī), numerous astronomical instruments, including astrolabes (suturlāb), quadrants (rub'dāire), and armillary spheres (felek topu) are listed. See TSMA, D. 10026. An earlier register dated 1496 likewise lists astronomical instruments. See Gülru Necipoğlu, Architecture, Ceremonial, and Power: The Topkapı Palace in the Fifteenth and Sixteenth Centuries (Cambridge: MIT Press, 1991), 134-35. 


\section{LIST OF ENTRIES}

\section{WORKS ON THE QUADRIVIUM}

(Taf̦̣illu kutubi 'ilmi al-nujūmi wa-kutubi 'ilmi al-hay’ati wa-kutubi 'ilmi al-ḥisābi wa-kutubi 'ilmi al-handasatiwa-kutubi 'ilmi al-mūsīqū)

Following the suggestion of Dimitri Gutas, all commentaries, supercommentaries, and glosses are listed under the title of the work on which they comment, but the authors of these commentaries are also listed separately with full reference to their works in the inventory. Under each author, the works are listed as follows: Integer numbers $(1,2,3)$ indicate separate works by the author. Lowercase letters (a, b, c) indicate separate copies of the same work, or separate works with the same title. Decimal numbers $(.1, .2, .3)$ indicate separate commentaries on the original work by various commentators. A second decimal number after a first (.1.1, .1.2, .1.3) indicates a supercommentary on a commentary of the listed work. Lowercase Roman numerals in parentheses, (i), (ii), (iii), indicate that the MS is a translation of the work.

The authors and their works are listed alphabetically. Definite articles, prepositions, and the words $R[i s \bar{a} l a], M[a q \bar{a} l a]$, and $K[i t a \bar{b}]$ are disregarded in the alphabetization.

\section{PART ONE}

The Science of the Stars ('ilm al-nujūm)

(including both ahkām al-nujūm and min qibal al-nujūm)

ABŪ MA'SHAR Ja'far ibn Muḥammad ibn 'Umar al-Balkhī (d. 886)

[1] 1. K. al-așlfì 'ilm al-nujūm (The Book of the Foundations in the Science of the Stars), Arabic, $317\{14\}$. Bound with Abū Ma'shar's Sarā’ir al-asrār. MANUSCRIPT: SK Hamidiye 824.

[2] 2. R. fi ihtirāqātal-kawākib (Treatise on the Combustion of the Stars), Arabic, $314\{9-10\}$. Bound with Kūshyār b. Labbān's al-Züj al-jāmi and Mujmal al-ușūl. MANUSCRIPT: SK Fatih 3418.

[3] 3. K. al-mudhäkarāt (Book of Recollections), Arabic, $319\{3-4\}$.

[4] 4. Muntakhab k. fi ạkām al-nujūm (The Selection from Abu Ma'shar's Book on Astrology), Arabic, $323\{8\}$. Bound with other unspecified texts on [the science of the] stars.

[5] 5. Muntakhab k. qirānāt (The Selection from the Book of Conjunctions), Arabic, $322\{6\}$.

[6] 6. Sarā'ir al-asrār (The Hidden Secrets of Secrets), Arabic, $317\{14-15\}$. Bound with Abū Ma'shar's K. al-aṣl fì ilm al-nujūm. MANUSCRIPT: SK Hamidiye 824.

'ALĪ B. '̄̄SĀ AL-USṬURLĀBĪ (fl. ninth century)

[7] 1. R.fíal-usturläb (Treatise on the Astrolabe), Arabic, $324\{7\}$. Bound with al-Tabarì's Firdaws al-hikma and al-Kharaqī's K. al-tabșira. EDITION: Louis Cheikho, "Kitāb al-'amal bi-l-asțurlāb li-'Alī ibn 'Isā," al-Mashriq 16 (1913): 29-46.

AL-ASHRAF, 'Umar b. Yūsuf b. 'Umar b. 'Alī b. Rasūl (d. 1296)

[8] 1. K. manhaj al-tullāb fí 'amal al-usțurlāb (The Students' Course on the Use of the Astrolabe), Arabic, $317\left\{13^{-14}\right\}$. 
AL-BALKHĪ, 'Alī b. Aḥmad (fl. twelfth century)

[9] 1. Mukhtașar madkhal ilā 'ilm ahkām al-nujūm (Abridgment of the Introduction to Astrology), Arabic, $317\{9\}$. Bound with a Persian translation of the same work. MANUSCRIPT: SK Ayasofya 2702, personal copy of Bayezid II.

[10] 1(i). Same as preceding, Persian, $317\{10\}$. Bound with the Arabic original. MANUSCRIPT: SK Ayasofya 2702, personal copy of Bayezid II.

AL-BATTĀNĪ, Abū 'Abd Allāh Muhammad b. Jābir b. Sinān al-Harrānī al-Ṣābi’ (d. 929-30)

[11] 1a. Arba'maqālātfí ahkām al-nujūm (Commentary of Ptolemy's Tetrabiblos), Arabic, $317\{8\}$. Bound with R. al-usțurläb.

[12] 1b. Same as preceding [catalogued in the inventory as Sharh maqālāt Bațlamyūs fi al-qad $\bar{a}^{\prime}$ bi-al-nujūm 'alā al-hawādith], 323 \{11-12\}.

AL-BīRŪNĪ, Abū Rayḥān Muhammad b. Aḥmad (d. 1048)

[13] 1a. Istīāb al-wujūh al-mumkina fì șan'at al-usțurlāb (Understanding All Possible Ways of Constructing the Astrolabe), Arabic, $322\{2-3\}$. MANUSCRIPT: SK Ayasofya 2576. EDITION: Istī $\bar{a} b$ al-wujūh al-mumkina fi șan'at al-usțurlāb, ed. al-Sayyid Muhammad Akbar Jawādī al-Ḥusaynī (Mashhad: Islamic Research Foundation, 2001/2002).

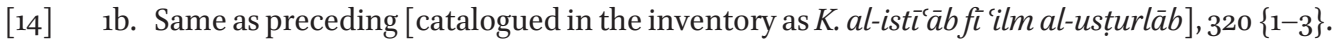
Bound with Sharaf al-Dīn al-Ţūsī's K. fì ma'rifat al-usțurlāb al-musațtah, Qusțā b. Lūqā’s K. $f i$ al-'amal bi-al-kura, al-Ṣūfi's $K$. fì al-'amal bi-al-kura, an anonymous treatise on the astrolabe, and an anonymous treatise on using the spherical astrolabe. MANUSCRIPT: According to the Islamic Scientific Manuscript Initiative database (https://ismi.mpiwg-berlin.mpg.de/), this codex might be TSMK A. 3505 (Karatay: A 7046). ${ }^{1}$

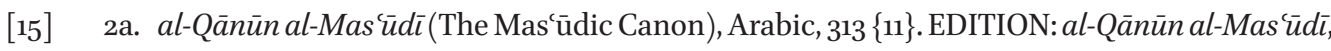
ed. 'Abd al-Karīm Sāmī al-Jundī, 3 vols. (Beirut: Dār al-Kutub al--ilmiyya, 2002).

[16] 2b. Same as preceding, $313\{11-12\}$.

[17] 3a. al-Tafhim li-awā'il (șinā'at) al-tanjïm (Book of Instruction in the First Principles of the Art of Astrology), 318 \{19\}. MANUSCRIPT: TSMK A. 3477 (Karatay: A 7050) and TSMK A. 3478 (Karatay: A 7051) house two copies of al-Tafhìm bearing Bayezid's seal. EDITION: Facs. ed. of the Arabic manuscript (London, British Library Or. 8349) and English trans. by R. Ramsay Wright: The Book of Instruction in the Elements of the Art of Astrology by al-Biruni (London: Luzac \& co., 1934); Persian edition: Jalāl al-Dīn Humāì̄, ed. (Tehran: Bābak, 1983).

[18] 3 b. Same as preceding, $320\{10\}$.

[19] 3c. Same as preceding, $320\{10\}$.

[20] 3d. Same as preceding, $323\{18\}$.

[21] 3e. Same as preceding, language specified as Arabic, $320\left\{13^{-14}\right\}$.

AL-BUKHĀRĪ, 'Alā al-Dīn 'Alī-Shāh b. Muḥammad b. Qāsim al-Khawārazmī (d. after 1291)

[22] 1. Athmār wa ashjār (Fruits and Trees), Persian, thirteenth century, $313\{16-17\}$. Bound with a copy of the Zïj-i ìlkhānī. See $\rightarrow$ al-Ṭūsī, 6, Part I. MANUSCRIPT: TSMK A. 3513 (Karatay: F 231).

AL-BUKHĀRI, 'Imad al-Dīn (fl. fifteenth century)

[23] 1. K. jadwal tashïl al-Qamar wa-jadwal tashïl 'Uțārid (Table for Facilitating [the Calculations of] the Moon and Mercury), $319\{2-3\}$. 
AL-BŪZJĀNĪ, Abū al-Wafā’ Muḥammad b. Muḥammad b. Yaḥyā (d. 997 or 998)

See also al-Būzjānī in Part Four ('ilmal-handasa).

[24] 1. Zïj al-wādih (Clear Astronomical Handbook of Tables) [catalogued in the inventory as Zïj

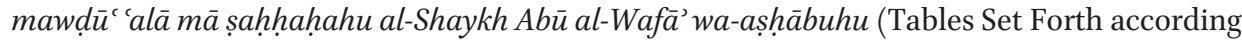
to What Was Corrected by the Master Abü'l-Wafä’’ and His Colleagues)], Arabic, $313\{16-17\}$.

AL-DĪRĪNĪ, 'Abd al-'Azīz b. Aḥmad b. Sa'īd al-Damīrī (d. 1297)

[25] 1. K. yawāqüt al-mawāqüt min qibal al-nujūm (The Rubies of Timekeeping), Arabic, $318\{15\}$. MANUSCRIPT: SK Ayasofya 2711, personal copy of Bayezid II.

EFEZĀDE, Muḥammad b. Khwāja Sulaymān al-Bursawī (d. after 1495)

[26] 1. Sharh bisst bāb dar usțurlāb (Commentary of al-Ṭūsīs Treatise on the Astrolabe), Persian, late fifteenth century, $321\{12\}$. See $\rightarrow$ al-Ṭūsī, 1.3, Part I. MANUSCRIPT: This codex should be the copy now housed as SK Ayasofya 2641.

AL-GHAZNAWĪ, Abū al-Maḥāmīd b. Mas'ūd (fl. late twelfth century)

[27] 1a. Kifäyat al-ta lìm [fí șinā’at al-tanjüm] (Sufficiency of Learning [in the Art of Astrology]), Persian, $316\{15\}$. MANUSCRIPT: SK Ayasofya 2699.

[28] 1b. Same as preceding, $316\{16\}$.

ḤAMZA B. 'ABD AL-KARĪM (d. after 1497)

[29] 1. K. miftāhal-nujūm (Book of the Key to the Stars), Persian, 313 \{14\}. MANUSCRIPT: TSMK R. $1706 .{ }^{2}$

IBN AL-HAYTHAM, Abū 'Alī al-Ḥasan b. al-Ḥasan (d. ca. 1040)

See also Ibn al-Haytham in Part Two ('ilm al-hay'a) and Part Four ('ilm al-handasa).

[30] 1. Qawl fi samt al-qibla (Book on the Azimuth of the Qibla), Arabic, $321\{1\}$. Bound in a volume containing Ibn al-Haytham's M. fi istikhräj khațt nisf fal-nahār and M. fí istikhräj irtifä́ al-quțb.

[31] 2. M. fi istikhräjkhaț̣ nisfal-nahär (Chapter on Computing the Meridian Line), Arabic, $321\{1\}$. Bound in a volume containing Ibn al-Haytham's Qawl fi samt al-qibla and M. fi istikhräj irtifä $a l-q u t+b$.

[32] 3. M. fü istikhräj irtifä al-quțb (Chapter on Computing the Altitude of the Pole), Arabic, 321 $\{1-2\}$. Bound in a volume containing Ibn al-Haytham's M. fi istikhräj khațt niş al-nahār and Qawl fi samt al-qibla.

IBN ‘ĀṢIM, Abū Bakr 'Abd Allāh b. Ḥusayn b. Ibrāhīm b. Ḥusayn (d. 1013)

[33] 1. K. al-anwāà wa-al-azmina wa-ma'rifat ayān al-kawākib (Weather Predicting Stars, Their Periods and Properties), Arabic, 321 \{18-19\}. MANUSCRIPT: TSMK A. 3508 (Karatay: A 7053). EDITION: Kitāb al-Anwā' wa-al-azmina wa-ma'rifat a yān al-kawākib, facs. ed. by Fuat Sezgin (Frankfurt: Institut für Geschichte der Arabisch-Islamischen Wissenschaften, 1985).

IDRIS AL-NABĪ or HERMES

[34] 1a. R. ahkām țulü'al-shi'rā (Treatise on the Judgments of the Appearance of Sirius), Arabic, 320 $\{4-5\}$.

[35] 1b. Same as preceding, $321\{11-12\}$.

[36] 1c. Same as preceding, $322\{8-9\}$. 
[37] 1d. Same as preceding [catalogued in the inventory as K. Hurmus fi ahkām al-nujūm], 323 $\left\{5^{-6}\right\}$. Bound in a volume containing astrological texts. ${ }^{3}$

IKHWĀN AL-ṢAFĀ' (fl. tenth cent.)

[38] 1a. K. Ikhwān al-Şafā’ fi funūn al-'ulüm (The Book of the Sincere Brethren on Different Sciences), Arabic, $319\left\{9^{-11}\right\}$. The description goes on to mention only the mathematical sciences as examples, which may indicate that the MS contained only those. EDITION: Epistles of the Brethren of Purity. On Astronomia: An Arabic Critical Edition and English Translation of Epistle 3, ed. Jamil Ragep and Taro Mimura (Oxford: Oxford University Press, 2015).

[39] 1b. Same as preceding, $319\{11-12\}$.

[40] 1c. Same as preceding, $319\{12-14\}$.

[41] 1d. Same as preceding, $319\{14\}$.

[42] 1e. Same as preceding, $324\{4-5\}$.

[43] 1(i). Same as preceding, Persian translation, $324\{2-4\}$.

AL-KĀSHĪ, Ghiyāth (al-Milla wa-) al-Dīn Jamshīd b. Mas'ūd b. Maḥmūd (d. 1429)

See also al-Kāshī in Part Three ('ilm al-hisāab).

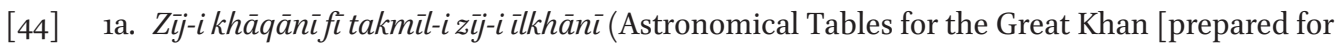
completing Ṭūsī's Tables]), Persian, 1413-14, 313 \{14-15\}. See $\rightarrow$ al-Ṭūsī, 6.2, Part I. MANUSCRIPT: SK Ayasofya 2692.

[45] ib. Same as preceding, $314\{6-7\}$.

AL-KĀSHĪ, Maḥmūd b. Yaḥyā b. al-Ḥasan (d. after 1411)

[46] 1a. Wilādat-i Iskandar b. 'Umar Shaykh b. Amīr Taymūr (The Birth Horoscope of Mīrzā Iskandar b. 'Umar Shaykh, son of Amir Timur), Persian, 1411, $319\{4-5\}$. MANUSCRIPT: Wellcome Institute Per. $474^{4}$

AL-KHALĪLĪ, Shams al-Dīn Abū 'Abdallāh Muhammad b. Muhammad (d. after 1360)

[47] 1. al-Jadwal al-āfāqū (The Table of Horizons), Arabic, $318\{19\}-319\{1\}$. MANUSCRIPT: TSMK A. 3500 (Karatay: A 7120$).^{5}$

[48] 1(i)a. [al-Qunawī] Tarjama K. al-jadwal al-āfāaī, $319\{1\}$. See $\rightarrow$ al-Qunawī, 4. MANUSCRIPT: SK Ayasofya 2590.

[49] 1(i)b. Same as preceding [catalogued in the inventory as Sharh al-ṣafā'ih al-äfäqiyya (Commentary on al-Khaliliı’s Table)], Turkish, 318 \{17\}. MANUSCRIPT: TSMK A. 3499 (Karatay: T 1618).

[50] 1(i)c. Same as preceding [catalogued in the inventory as Tarjama R. al-șafäih al-āfāqiyya], 321 $\{4-5\}$.

AL-KHIṬĀBĪ AL-ḤUSAYNĪ, Ḥusām b. Shams al-Dīn al-Lāhijānī al-Gīlānī (d. after 1495)

[51] 1. R. Tashrịh al-älāt fi shàn al-imtihāanāt (Description of Instruments Pertaining to Testing), Persian, 1483, 317 \{2\}. MANUSCRIPT: MS Tehrān, Majlis-i Shūrā-yi Islāmī 6376. EDITION: Mortaza Somi and Mohammad Bagheri, "Risāla-i tashrị̣ al-ālāt fī sha'n al-imtiḥānāt az Sayyid

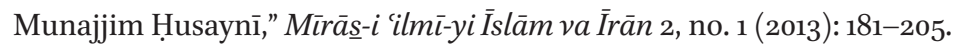

[52] 2. K. țāli-i iwilādat-i Sulțān Mehemmed b. Sulțān Murād (Birth Horoscope of Mehmed II, son of Murad II), Persian, 1480, $319\{6-7\}$. MANUSCRIPT: TSMK YY. 830 (Karatay: F 246). 


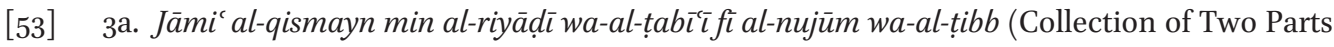
from Mathematical and Medical Sciences), Persian, 1479-80, autograph, $319\{16-17\}$.

[54] 3b. Same as preceding [catalogued in the inventory as R. bi-al-färisiyyafial-nujūm wa-al-țibb], $318\{16-17\}$. MANUSCRIPT: This particular copy $(3 \mathrm{~b})$ is at SK Ayasofya $2414-\mathrm{M}$.

[55] 4. Sharh Sì faṣl al-musammā bi-muwaḍ̣̂h al-rusūm fì iilm al-nujūm (Commentary on [alṬūsì's] Thirty Chapters on the Knowledge of the Almanac), Persian, 1479, autograph, 319 \{1718\}. See $\rightarrow$ al-Ṭūsī, 3.1, Part I. MANUSCRIPT: SK Ayasofya 2709.

AL-KŪHISTĀNĪ, Fasīh al-Dīn Muḥammad b. 'Abd al-Karīm Niẓāmī (d. 1530)

[56] K. mi yār-i äfitāb fi sharh-i bìst bāb (The Scale of the Sun), Persian, 1490-91, $319\left\{5^{-6}\right.$. MANUSCRIPT: SK Ayasofya 2677. See $\rightarrow$ al-Ṭūsī, 1.4, Part I.

KŪSHYĀR b. LABBĀN, Kiyā Abū al-Ḥasan Bāshahrī al-Jīlī (d. after 1025)

[57] 1a. Mujmal al-ușūl (Compendium of [Astrological] Principles) [also known as al-Mudkhal fi șinā'at ahkām al-nujūm (Introduction to Astrology)], Arabic, 992, 314 \{8-9\}. Bound with Kūshyār b. Labbān's al-Zīj al-jāmi' and Abū Ma'shar's R. fi i ịtiraqāt al-kawākib. MANUSCRIPT: SK Fatih 3418. EDITION: Kūshyār ibn Labbān's Introduction to Astrology, ed. Michio Yano (Tokyo: Tokyo University of Foreign Studies, 1997).

[58] 1b. Same as preceding, $322\{6-7\}$.

[59] 1c. Same as preceding [catalogued in the inventory as K. mudkhal al-nujüm], $316\{19\}$. Bound with two anonymous treatises, $K$. zubdat al-raml and $K$. țălī $a l$-waqt.

[6o] 1d. Same as preceding, $317\{1\}$. Bound with an anonymous K. uṣull al-malāhim.

[61] 1e. Same as preceding, language specified as Persian, $313\{12-13\}$.

[62] If. Same as preceding [catalogued in the inventory as K.fíahkām al-nujūm], 316 \{17-18\}. Bound with al-Ṭusis's Tarjama K. Thamara-i Bațlamyūs. MANUSCRIPT: This codex (If) should be the copy now housed as Beyazıt Library Beyazıt 4640.

[63] 1g. Same as preceding, $319\{8\}$. Bound with Burhān al-hay'a and two anonymous treatises on the science of the stars.

[64] Ih. Same as preceding, $322\{4\}$. Bound with al-Ṭūsìs Tarjama K. Thamara-i Bațlamyūs.

[65] 2. al-Zïjal-jāmic (Comprehensive Astronomical Handbook with Tables), Arabic, $314\{8\}$. Bound with Kūshyār b. Labbān's Mujmal al-uṣūl and Abū Ma'shar's R. fi ihtiraqāt al-kawākib. MANUSCRIPT: SK Fatih 3418.

[66] 3. R. al-'amal [bi-] al-usturlāb (Treatise on the Use of the Astrolabe), Arabic, $321\{4\}$. Bound in a volume containing $R$. fi 'amal al-șafiha and other treatises. MANUSCRIPT: This codex should be the copy now housed as SK Ayasofya $2671 .{ }^{6}$ EDITION: Persian translation: Risāla-yi Usțurlāb-i Kūshyār Gīlānī, ed. Muhạmmad Bāqiīi (Tehran: Mīrās̄i Maktūb, 2014).

AL-MARRĀKUSHĪ, Sharaf al-Dīn Abū 'Alī al-Ḥasan b. 'Alī (fl. late thirteenth century)

[67] 1a. Jāmi' al-mabādi' wa-al-ghāyātfí 'ilmal-mīqāt (Comprehensive Collection of Principles and Goals in the Science of Timekeeping), Arabic, $1276-82,318\{4-5\} .^{7}$

[68] 1b. Same as preceding, $318\{6\}$. MANUSCRIPT: These two codices (1a, $1 \mathrm{~b})$ should be the copies now housed as SK Ayasofya 2669 and TSMK A. 3343 (Karatay: A 7079), personal copy of Bayezid II. EDITION: Jāmi' al-mabādi’ wa-l-ghāyāt fì ilm al-mīqāt, facs. ed. of TSMK A. 3343, ed. Fuat Sezgin, 2 vols. (Frankfurt: Institut für Geschichte der Arabisch-Islamischen Wissenschaften, 1984). 
MAWLĀNĀ KŪCHAK, Yazdānbakhsh b. Pīr 'Alī al-Amāsī (d. after 1476)

[69] 1. Zij-i Mujmal (Summary Handbook of Astronomical Tables), Arabic, 1476, autograph, 314 \{1-2\}. MANUSCRIPT: TSMK R. 1713 (Karatay: A 7126).

AL-MIZZĪ, Zayn al-Dīn Abū 'Abd Allāh Muḥammad b. Aḥmad b. 'Abd al-Raḥīm (d. 1349)

[70] 1a. R. Kashfal-raybfial-'amal bi-al-jayb (Dispelling Doubt in Working with the Sine Quadrant), Arabic, fourteenth century, $316\{11\}$.

[71] 1b. Same as preceding, $324\{9-10\}$. Bound with al-Mizzī's al-Rawdāt al-muzaharrātfíal-'amal bi-al-muqanțarāt and Jamāl al-Dīn al-Turkistānī's $R$. 'alā'iyya fí al-ḥisāb. MANUSCRIPT: This codex (1b) should be the copy now housed as TSMK A. 3119 (Karatay: A 7037). ${ }^{8}$

[72] 2. al-Rawḍatal-muzaharrātfíal-'amal bi-al-muqanțarāt (Flower-Filled Gardens for Using the Almucantars Quadrant), Arabic, $324\{9\}$. Bound with al-Mizzī's R. Kashf al-rayb fi al-'amal bi-al-jayb and Jamāl al-Dīn al-Turkistānī's $R$. 'aläìyy a fi al-hisāb.

MANUSCRIPT: This codex should be the copy now housed as TSMK A. 3119 (Karatay: A 7037). ${ }^{9}$

[73] 3. R. fíal-rub'al-dä'ira (Treatise on the Circular Quadrant), $318\{3-4\}$. Bound with al-Ṭūsìs $R$. bist bāb, Sīfaṣl, and $R$. fì al-rub`al-mujayyab. MANUSCRIPT: SK Ayasofya 2621.

MĪRIM ÇELEBĪ, Mạ̣mūd b. Muhammad b. Qāḍīzāde al-Rūmī (d. 1525)

[74] 1. Sharh-i Zïj-i Ulugh Beg (Commentary on Ulugh Beg's Astronomical Handbook of Tables), Persian, 1499, autograph, $315\{17-18\}$. See $\rightarrow$ Ulugh Beg, 1.2, Part I. MANUSCRIPT: SK Ayasofya 2697 .

MUNAJJIM BĀLİ (d. after 1481)

[75] 1. R. Tuhfatal-faqïrfírub'al-dä'ira (Treatise of the Gift of the Impoverished on the Quadrant), Persian, 1481, autograph, $323\{19\}$. MANUSCRIPT: SK Ayasofya 2588.

AL-NĪSĀBŪRĪ, al-Ḥasan b. Muḥammad b. al-Ḥusayn Nizāām al-Dīn al-A'raj (d. ca. 1329-30) See also al-Nīsābūrī in Part Two ('ilm al-hay'a) and Part Three ('ilm al-ḥisāb).

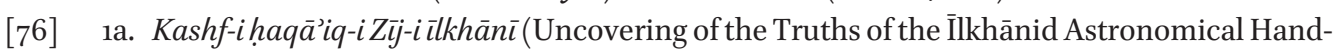
book of Tables), Persian, 1308-9, autograph, $315\{19\}-316\{1\}$. See $\rightarrow$ al-Ṭūsī, 6.3, Part I.

[77] 1b. Same as preceding, $315\left\{13^{-14}\right\}$.

[78] 1c. Same as preceding, $315\left\{14^{-15}\right\}$.

[79] 1d. Same as preceding, $315\left\{15^{-16}\right\}$.

[80] 1e. Same as preceding, $315\{18-19\}$. MANUSCRIPT: This last book (1e) should be the copy now housed as SK Ayasofya 2696.10

PTOLEMY (d. 170)

[81] 1a. K. al-Thamara li-Bațlamyūs (The Centiloquium or One Hundred Sayings), conventionally attributed to Ptolemy but likely written by a certain Aḥmad b. Yūsuf al-Miṣrī, Arabic, $190\{6\}$. Bound with al-Ṭusì's Tarjama/Sharh al-Thamara and other treatises. [Catalogued under Kutub al-siyar wa-al-tawārïkh, etc.]

[82] 1 b. Same as preceding [catalogued in the inventory as K. al-shajara wa-al-thamara fi ahkām al-nujūm ], 322 \{11\}. Bound with R. fi al-hisāb.

[83] 1c. Same as preceding, $324\{13\}$. Bound with R. min qibal al-nujūm, R. fíạkām al-nujüm, R. alwafq, and K. al-șibyān fíal-lugha.

[84] 1.1a. "Sharh Thamara-i Bațlamyūs" (Commentary on the Centiloquium), $320\{17-18\}$. 
[85] 1.1b. Same as preceding, $322\{10\}$.

[86] 1(i)a. [al-Ṭūsī] Tarjama-i Thamarah-i Bațlamyūs (The Translation of the Centiloquium), Persian, $316\{18\}$. Bound with Kūshyār's K. ahkām al-nujūm. See $\rightarrow$ al-Ṭūsī, 5, Part I.

[87] 1(i)b. Same as preceding, $318\{18\}$.

[88] 1(i)c. Same as preceding, $321\{8\}$. MANUSCRIPT: This codex $(1(\mathrm{i}) \mathrm{c})$ should be the copy now housed as SK Ayasofya 2695 .

[89] 1(i)d. Same as preceding, $322\{3\}$. Bound with Kūshyār's Mujmal al-uṣūl.

[90] 1(i)e. Same as preceding, $190\{7\}$. Bound with (pseudo-Ptolemy's) K. al-Thamara and other treatises. [Catalogued under Kutub al-siyar wa-al-tawārīkh, etc.]

AL-QAȘRĀNĪ, Ya'qūb b. 'Alī (fl. likely ninth century)

[91] 1a. K. al-Masā'il (Book of Interrogations), Arabic, 320 \{14-15\}. MANUSCRIPT: TSMK A. 3492 (Karatay: A 7114).

[92] 1b. Same as preceding, $320\{15\}$.

[93] 1c. Same as preceding, $320\{16\}$.

[94] 1d. Same as preceding, $320\{17\}$.

AL-QUNAWĪ, Muḥammad b. al-Kātib Sīnān (d. ca. 1523-24)

[95] 1. R. müdih al-awqātfíma' rifat al-muqanțarāt (Elucidator of Times on Understanding the Almucantars [Quadrant]), Arabic, 318 \{7\}. MANUSCRIPT: TSMK A. 3481 (Karatay: A 7122).

[96] 2. R. tabȳ̄n al-awqātfìma'rifat wad' al-rukhāmāt (Treatise on Explanation of Times for Understanding the Setting up of Sundials), Arabic, $318\{12-13\}$. MANUSCRIPT: TSMK A. 3501 (Karatay: A 7121).

[97] 3. Tarjamar. al-jayb (Turkish Translation of a Treatise on the Sine Quadrant), Turkish, $316\{10\}$. MANUSCRIPT: SK Ayasofya 2594.

[98] 4a. Tarjama K. al-jadwal al-äfāqī (Translation of [al-Khalīì's] Table of Horizons), Turkish, 319 \{1\}. MANUSCRIPT: SK Ayasofya 2590. See $\rightarrow$ al-Khalīlī, 1(i).

[99] 4b. Same as preceding [catalogued in the inventory as Tarjama r. al-șafä ih al-äfäqiyya], 321 $\{4-5\}$.

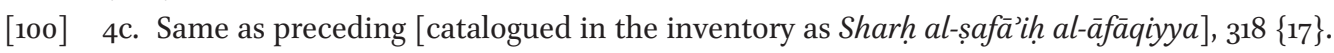
MANUSCRIPT: TSMK A. 3499 (Karatay: T 1618).

[101] 5. Tuhfat al-fuqarā’ fi rub`al-dä'ira (The Gift of the Impoverished on the Quadrant of the Circle), Arabic, $318\{7-8\}$.

QUSṬ̂̄ B. LŪQĀ AL-BA'LABAKKĪ (d. ca. 912-13)

[102] 1a. K. fì al-'amal bi-al-kura [al-nujümiyya] (Book on Using the Celestial Globe), Arabic, 317 $\{16-17\}$. Bound with $R$. fi al-farq bayn al-dāa $d w a-a l-z \bar{a}$ ' and other unspecified treatises." ${ }^{11}$ EDITION: Richard Lorch and José Martínez Gázques, "Qusta ben Luca: De sphere uolubili” [edition of its Latin translation], Suhayl 5 (2005): 9-62.

[103] 1b. Same as preceding, $320\{1\}$. Bound with Sharaf al-Dīn al-Ṭūsī's $K$. fì ma'rifat al-usturlāb almusattah, al-Ṣūfi's K. fí al-'amal bi-al-kura, al-Bīrūnī's K. fi istīāāb al-wujūh, an anonymous treatise on the astrolabe, and another anonymous treatise on using the spherical astrolabe. MANUSCRIPT:According to the Islamic Scientific Manuscript Initiative database (https://ismi. mpiwg-berlin.mpg.de/), this codex might be TSMK A. 3505 (Karatay: A 7046). ${ }^{12}$ 
[104] 1c. Same as preceding, $320\{6\}$. Bound with an anonymous treatise on the spherical astrolabe, an anonymous treatise on the astrolabe, and R. al-'amalbi-al-rub'al-mawdị'fihial-muqanțarāt. MANUSCRIPT: This codex (1c) should be the copy now housed as SK Ayasofya 2638.

[105] 1d. Same as preceding [catalogued in the inventory as K. al-'amal bi-al-kura fi al-nujūm], 322

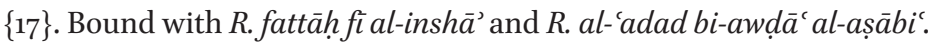

[106] 1e. Same as preceding, $319\{16\}$. MANUSCRIPT: This codex (1e) should be the copy now housed as TSMK A. 3475 (Karatay: A 7040).

[107] if. Same as preceding [catalogued in the inventory as R. al-'amal bi-al-kura al-falakiyya], 324 $\{10-11\}$. Bound with $K$. da'a $\bar{a} w \bar{a}$ Uqlìdus. MANUSCRIPT: This codex (1f) should be the copy now housed as SK Ayasofya 2635 .

[108] 1g. Same as preceding [catalogued in the inventory as R. al-kura al-falakiyya min qibal alnujūm ], $326\{3\}$. MANUSCRIPT: This codex (1g) should be the copy now housed as SK Ayasofya 2633.

[109] 1h. Same as preceding, 311 \{3\}. Bound with Sharh Mìrak li-ḥikmat al-Hidāya, R. fi al-mūsīqū, K. fi ma'rifat al-ghālib wa-al-maghlūb. [Catalogued under kutub 'ilm al-ta'bìr, etc.] MANUSCRIPT: SK Ayasofya 2432, personal copy of Bayezid II.

[110] 2a. K. fíal-'amal bi-al-kura dhät al-kursì (On the Use of the Mounted Celestial Sphere), Arabic, $320\{11-12\}$. Bound with five treatises on the use of the quadrant.

[111] 2b. Same as preceding, Persian, $324\{5\}$. MANUSCRIPT: This codex (2b) should be the copy now housed as SK Ayasofya 2631.

AL-QŪSHJ̄̄, Abū al-Q̨āsim 'Alā’ al-Dīn 'Alī b. Muḥammad (d. 1474)

See also al-Qūshjī in Part Two ('ilm al-hay'a) and Part Three ('ilm al-hisāb).

[112] 1a. Sharh-i Zij-i Ulugh Beg (Commentary of Ulugh Beg's Astronomical Handbook of Tables), Persian, $315\{16-17\}$. See $\rightarrow$ Ulugh Beg, 1.1, Part I.

[113] 1b. Same as preceding, $316\{1-2\}$. MANUSCRIPT: One of these copies should be TSMK A. $3318 .{ }^{13}$

AL-RĀZĪ, Fakhr al-Dīn Abū 'Abdallāh Muhammad b. 'Umar b. al-Khațīb (d. 1210)

[114] 1a. Ikhtiyārātal-ahkām al-'alā'iyya (On the Selection of Propitious Times for Various Acts and Affairs), Arabic/Persian, $318\{1\}$.

[115] 1b. Same as preceding, $318\{1-2\}$.

[116] 1c. Same as preceding, language specified as Persian, $320\{8-9\}$. MANUSCRIPT: TSMK R. 1705 (Karatay: F 228).

[117] 1d. Same as preceding, $318\{11\}$. Bound with al-Sijzìs K. al-dalä’ilfí ahkām al-nujūmm.

AL-RĀZĪ, Shahmardān b. Abū al-Khayr (d. after 1072)

[118] 1. Rawḍt al-munajjimīn (The Garden of Astrologers), Persian, $314\{3\}$. Bound with al-Ṭusì’s Züj-i ìlkhānī, al-Shīrāzì's Fann Uqlïdus min K. durrat al-tāj, Sayyid Munajjim's K. ahkā̄m al-a wām, al-Bakrī's Burhān al-kifāya, and Tuhfat al-gharā’ib. EDITION: Rawzat al-munajjimīn, ed. Khalìl Akhavān Zanjānī (Tehran: Mīrās-i Maktūb, 2003/2004).

IBN ABĪ AL-RIJĀL (d. after 1037)

[119] 1. K. al-Bāric (Summa on Astrology), Arabic, 316 \{17\}. EDITION: Aly Aben Ragel, El Libro conplido de los iudizios de las estrellas (Spanish translation), ed. and trans. Gerold Hilty (Madrid: Real Academia Española, 1954). 
SAYYID MUNAJJIM (fl. first half of the fifteenth century)

[120] 1. K. ahkām al-a'wām (General Astrological Judgments), Persian, 314 \{5\}. Bound with al-Rāzìs Raw dat al-munajjimīn, al-Ṭūsìs Zïj-i ìlkhānī, al-Shīrāzì's Fann Uqlīdus min K. durrat al-tāj, alBakrìs Burhān al-kifāya, and Tuhfat al-gharāib.

AL-SIJZİ, Abū Sāīd Aḥmad b. Muḥammad b. 'Abd al-Jalīl (d. ca. 1020)

[121] 1. K. al-dalầil fi ahkām al-nujūm (Book of the Signs in Astrological Judgments), Arabic, 318 \{11-12\}. Bound with al-Rāzī's K. Ikhtiyārāt al-ậkāmal-'alā’iyya.

[122] 2. R. al-usțūrläb al-zawraqī (Treatise on Mariners' Astrolabe), Arabic, $322\{7-8\}$.

AL-Ș̄̄Tİ, Abū al-Ḥusayn ‘Abd al-Raḥmān b. 'Umar (d. 986)

[123] 1a. K. șuwar al-burūj wa-al-kawākib fi al-nujūm (Book of the Images of the Constellations and Fixed Stars), 326 \{5-6\}. EDITION: Kitāb șuwar al-kawākib, facs. ed. by Fuat Sezgin (Frankfurt: Institut für Geschichte der Arabisch-Islamischen Wissenschaften, 1986).

[124] 1b. Same as preceding, Persian, $321\left\{15^{-16}\right\}$.

[125] 1.1. "Mukhtașarfiș șuwar al-kawākib," Persian, $321\{16-17\}$.

[126] 1.2. [al-Ṭūsī] Tarjama-i k. suwar al-kawākib, Persian, 1250, autograph, $317\{3-4\}$. See $\rightarrow$ al-Ṭūsī, 4, Part I. MANUSCRIPT: SK Ayasofya 2595

[127] 2a. K. al-'amal bi-al-usțurläb (Book on the Use of the Astrolabe), Arabic, $317\{11\}$. Bound with Ḥāmid b. 'Alī al-Wāsițị's work on the use of the astrolabe. MANUSCRIPT: TSMK A. 3509 (Karatay: A 7045). EDITION: Kitäbān fí al-'amal bi-al-asturlāb (Two Books on the Use of the Astrolabe), ed. Fuat Sezgin (Frankfurt: Institut für Geschichte der Arabisch-Islamischen Wissenschaften, 1986). [Text 1: Kitäb al-'amal bi-l-asturläb in 402 chapters, facsimile of TSMK A. 3509. Text 2: Risāla fíl-'amal bi-l-asțurlāb in 170 chapters, facsimile of SK Ayasofya 2642.]

[128] 2b. Same as preceding, $320\{12\}$. Bound with al-'Urḍi's work on using the sphere. MANUSCRIPT: This codex (2b) should be the copy now housed as TSMK A. 3491 (Karatay: A 7047).

[129] 3. K. fi al-'amal bi-al-kura (Book on Using the Sphere), Arabic, $319\{18\}$. Bound with Sharaf al-Dīn al-Ṭūsìs K. fì ma'rifat al-usțurlāb al-musațtah, Qusțā b. Lūqā's K. fì al-'amal bi-al-kura, al-Bīrūnì's K. fi istī'āb al-wujūh, an anonymous treatise on the astrolabe, and anonymous treatise on using the spherical astrolabe. MANUSCRIPT: According to the Islamic Scientific Manuscript Initiative database (https://ismi.mpiwg-berlin.mpg.de/), this codex might be TSMK A. 3505 (Karatay: A 7046$\} .14$

AL-ṬŪSĪ, Nașīr al-Dīn Abū Ja far Muhammad b. Muhammad (d. 1274)

See also al-Ṭūsī in Part Two ('ilm al-hay'a), Part Three ('ilm al-hisāb), and Part Four ('ilm al-handasa).

[130] 1a. R. Bìst bāb fì márifat dar usțurlāb (Twenty Chapters on Understanding the Astrolabe), Persian, 318 \{2\}. Bound with al-Ṭūsì's Sì faṣl, al-Mizzī’s R. fì al-rub`al-dā'ira, and R. fí al-rub`almujayyab. MANUSCRIPT: SK Ayasofya 2621. EDITION: Risāla-i bisst bāb dar márifat-i asțurlāb, ed. Mudarris Riżavī and Muḥammad Taqī (Tehran: Intishārāt-i Dānishgāh-i Tihrān, 1956).

[131] 1b. Same as preceding, $322\{12-13\}$. Bound with $R$. fì nazm Rashìd al-Dìn al-Wațāt fì 'ilm al-'arūd. MANUSCRIPT: SK Ayasofya 2620.

[132] 1c. Same as preceding [catalogued in the inventory as R. al-usțuläb], $317\{7\}$. Bound with alȚūsìs Sĭfașl and Madkhal-i manzūm. MANUSCRIPT: This codex (1c) should be the copy now housed as SK Ayasofya 2701. 
[133] 1d. Same as preceding [catalogued in the inventory as Mukhtașar fi márifat al-usțūrläb], 317

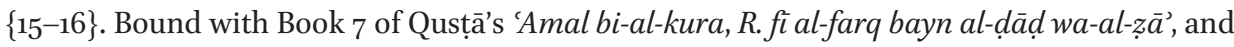
other unspecified treatises.

[134] 1.1a. "Sharh-i bisst bāb fi márifat al-usțurlāb" (Commentary on Twenty Chapters), $317\{19\}$.

[135] 1.1b. Same as preceding, $318\{8-9\}$. Bound with $R$. fi kayfiyyat al-amal bi-al-usțurlāb al-kurí. MANUSCRIPT: This codex (1.1b) should be the copy now housed as SK Ayasofya 2642.

[136] 1.2. "K. bisst bāb al-muhashshä" (Twenty Chapters with Glosses) $321\{17-18\}$.

[137] 1.3. [Efezāde] Sharh-i bist bāb fima'rifat al-usțurlāb, $321\{12\}$. See $\rightarrow$ Efezāde. MANUSCRIPT:This codex (1.3) should be the copy now housed as SK Ayasofya 2641.

[138] 1.4. [al-Kūhistānī] K. mi'yār-i äfitāb fì sharh-i bist bā b" (The Scale of the Sun), Persian, 1490-91, $319\left\{5^{-6}\right\}$. See $\rightarrow$ al-Kūhistānī. MANUSCRIPT: SK Ayasofya 2677 .

[139] 2a. Madkhal-i manzūm (On the Propitious Hours for the Beginning of Various Undertakings [often attributed to al-Ṭūsī]]), Persian, $317\{6\}$. Bound with al-Ṭūsì's Sī faṣl and R. al-usțurlāb. MANUSCRIPT: SK Ayasofya 2701.

[140] 2b. Same as preceding, $321\{2-3\}$. Bound with al-Ṭūsī's Sì fașl and other unspecified treatises.

[141] 2c. Same as preceding, 148 \{12\}. Bound with K. al-figh bi-al-fārisiyya al-manzūma and Sharh al-Farrǟ' al-lämiyya fi al-tașawwuf. [Catalogued under Kutub al-tașawwuf, etc.]

[142] 2d. Same as preceding, $227\left\{13^{-14}\right\}$. Bound with Qașïdat Salmān al-mușanna 'ät and Munsha'āt al-Wahìi al-Tabrïzī. [Catalogued under al-dawāwìn al-'arabiyya, etc.]

[143] 2e. Same as preceding, $363\left\{5^{-6}\right\}$. Bound with Tuhfa-i shāhī fi ma'rifat al-usțurlāb, Sharh al-Namaț al-tāsi' min al-Ishārāt, R. fì al-raml, and Sharh al-qașīda al-mansūba ilā Ibn Sīnā fì al-hikma. [Catalogued under kutub al-hikma al-islāmiyya.]

[144] 3a. R. Sì fașl, also known as Mukhtașar dar ma'rifat-i taqwìm (Thirty Chapters on the Knowledge of the Almanacs), Persian, 126o, 316 \{12\}. Bound with al-Zanjānī’s R. al-käfiya fí al-ḥisāb. MANUSCRIPT: SK Ayasofya 2732. EDITION: Muhtasar fi ilm el-tencim ve-ma'rifet el-takvim = Risale-i Sifasl (fourteenth-century Turkish translation of Ahmed-i Dai), ed. Tahir Nejat Gencan and Muammer Dizer (Istanbul : Boğaziçi Üniversitesi Kandilli Rasathanesi, 1984).

[145] 3b. Same as preceding, $316\{14\}$. Bound with $K$. al-hidāya fi al-hikma al-falsafiyya and al'Ubaydī's Sharh k. al-Chaghmin̄i. MANUSCRIPT: SK Ayasofya 2474, personal copy of Bayezid II.

[146] 3c. Same as preceding, 317 \{6\}. Bound with al-Ṭūsìs Madkhal-i manžūm and R. al-usțurlāb. MANUSCRIPT: SK Ayasofya 2701.

[147] 3d. Same as preceding, $318\{3\}$. Bound with al-Țūsì's R. bist bābfimárifat al-usțurläb, al-Mizzìs R. fi al-rub'al-dā'ira, and R. fi al-rub'al-mujayyab. MANUSCRIPT: SK Ayasofya 2621.

[148] 3e. Same as preceding, $318\{10-11\}$. Bound with al-Ṭūsì's Zubdat al-idrāk.

[149] 3 f. Same as preceding, 321 \{2\}. Bound with al-Ṭūsìs Madkhal-imanzūm and other unspecified treatises.

[150] 3g. Same as preceding, language specified as Arabic, $321\{9\}$.

[151] 3 h. Same as preceding, $322\{14-15\}$. Bound with Suhrawardì's K. al-alwäh al-imädiyya fi al-hikma al-falsafiyya.

[152] 3i. Same as preceding [catalogued in the inventory as Mukhtașar fi ma'rifat al-taqwìm fi al-nujüm], $321\{15\}$.

[153] 3.1. [al-Khițābī] Muwaḍ̣̂ị al-rusūm, Persian, 1478, 319 \{17-18\}. See $\rightarrow$ al-Khițābī, 4. MANUSCRIPT: SK Ayasofya 2709.

[154] 3.2a. "Sharh-i Sĩfaṣl," $321\{8-9\}$. 
[155] 3.2b. Same as preceding, $323\{2-3\}$. Bound as the final text in a compilation, which has as its first text Ibn al-Haytham's Hall shukūk fi K. al-Majisțī.

[156] 3.2c. Same as preceding, language specified as Arabic, $323\{16\}$.

[157] 3.2d. Same as preceding, language specified as Arabic, $323\{16-17\}$. MANUSCRIPT: One of the two codices (3.2c, $3.2 \mathrm{~d}$ ) should be the copy now housed as SK Ayasofya $2664 \cdot \cdot^{15}$

[158] 4. Tarjama-i k. șuwar al-kawākib (Translation of al-S̄ufi's Star Catalogue), Persian, 1250, autograph, $317\{3-4\}$. See $\rightarrow$ al-Ṣufî, 1.2. MANUSCRIPT: SK Ayasofya 2595.

[159] 5a. Tarjama-i Thamarah-i Bațlamyūs (The Translation of the Centiloquium), Persian, $316\{18\}$. Bound with Kūshyār's K. ahkām al-nujūm. See $\rightarrow$ Ptolemy, 1.1. EDITION: Sharh-i Thamarah-i Bațlamyūs dar aḥkām-i nujūm, ed. Khalīl Akhavān Zanjānī (Tehran: Āyīna-i Mīrās, 1999).

[160] 5b. Same as preceding, $318\{18\}$.

[161] 5c. Same as preceding, $321\{8\}$. MANUSCRIPT: This codex (5c) should be the copy now housed as SK Ayasofya 2695 .

[162] 5d. Same as preceding, $322\{3\}$. Bound with Kūshyār's Mujmal al-uṣūl.

[163] 5e. Same as preceding, $190\{7\}$. Bound with (pseudo-Ptolemy's) K. al-Thamara and other treatises. [Catalogued under Kutub al-siyar wa-al-tawärīkh, etc.]

[164] 6a. Zïj-i ìlkhānī(Ilkhanid Astronomical Handbook of Tables), Persian, autograph, 313 \{19\}-314 \{1\}. EDITION: Zīj-i īlkhānī, facs. ed. of the Persian manuscript (Kitābkhānah-i Majlis-i Shūrā-yi îslāmī), ed. Yūsuf Bayg Bābāpūr and Mas'ūd Ghulāmīyah (Tehran: Majma'-i Zakhā’ir-i İslāmī, 2012).

[165] 6b. Same as preceding, $313\{16\}$. Bound with K. athmār wa ashjār. See $\rightarrow$ al-Bukhārī, Part I. MANUSCRIPT: TSMK A. 3513 (Karatay: F 231).

[166] 6c. Same as preceding, $313\{18\}$.

[167] 6d. Same as preceding, $313\{18\}$.

[168] 6e. Same as preceding, $314\{3-4\}$. Bound with al-Rāzì's Raw dat al-munajjimīn, al-Shīrāzī’s Fann Uqlīdus min K. durrat al-tāj, al-Bakrī's Burhān al-kifāya, Sayyid Munajjim's K. ahkāmm al-a wām, and Tuhfat al-gharä'ib.

[169] 6.1. "Sharh-izzìj-i ìlkhānī," $315\{18\}$.

[170] 6.2a. [al-Kāshī] Züj-i khāqānî fí takmīl-i zìj-i ìlkhānī (Astronomical Tables for the Great Khan [prepared for consummating Ṭūsī's Tables]), Persian, 1413-14, $313\{14-15\}$. See $\rightarrow$ al-Kāshi, Ghiyāth al-Dīn, Part I.

[171] 6.2b. Same as preceding, $314\{6-7\}$. MANUSCRIPT: SK Ayasofya 2692.

[172] 6.3a. [al-Nisābūrī] Kashf-i haqā’iq-i Züj-i ìlkhānī (Uncovering of the Truths of the Ilkhanid Astronomical Handbook of Tables), Persian, 1308-9, autograph, 315 \{19\}-316 \{1\}. See $\rightarrow$ al-Nissābūrī, Part I.

[173] 6.3b. Same as preceding, $315\left\{13^{-14}\right\}$.

[174] 6.3c. Same as preceding, $315\{14-15\}$.

[175] 6.3d. Same as preceding, $315\left\{15^{-16}\right\}$.

[176] 6.3e. Same as preceding [catalogued in the inventory as Sharh Zǜ ìlkhānīal-musammā bi-kashf$i z \bar{j}$-i i llkhānī], 315 \{18-19\}. MANUSCRIPT: This codex (6.3e) should be the copy now housed as SK Ayasofya 2696. ${ }^{16}$

AL-ṬŪSĪ, Sharaf al-Dīn Muẓaffar b. Muḥammad b. al-Muẓaffar (d. 1213)

[177] 1. K. fi ma'rifat al-usțurläb al-musațtah (Book about the Knowledge of the Flat Astrolabe), 319 \{18-19\}. Bound with Qusțā b. Lūqā’s K. fì al-'amal bi-al-kura, al-Ṣufís K. fíal-'amal bi-al-kura, al-Bīrūnì's $K$. fì istī'āb al-wujūh, an anonymous treatise on the astrolabe, and an anonymous 
treatise on using the spherical astrolabe. MANUSCRIPT: According to the Islamic Scientific Manuscript Initiative database (https://ismi.mpiwg-berlin.mpg.de/), this codex might be TSMK A. 3505 (Karatay: A 7046). ${ }^{17}$

ULUGH BEG, Muḥammad Ṭaraghāy b. Shāhrukh b. Tīmūr (d. 1449)

[178] 1a. Zïj-i Ulugh Beg (Astronomical Handbook of Tables of Ulugh Beg), Persian, $313\{15\}$. MANUSCRIPT: SK Hamidiye 844. EDITION: Uluğ Beğ'in Astronomi Cetvelleri = Zic-i Uluğ Bey, facs. ed. and Turkish trans. Mustafa Kaçar and Atilla Bir, 2 vols. (Ankara: Kültür ve Turizm Bakanlığı, 2012).

[179] 1b. Same as preceding, $313\{17\}$.

[180] 1c. Same as preceding, $313\{18-19\}$.

[181] 1d. Same as preceding, $314\{2\}$.

[182] 1e. Same as preceding, $314\{7\}$.

[183] 1.1a. ['Alī al-Qūshjī] Sharh -i Zỉj-i Ulugh Beg (Commentary on Ulugh Beg's Astronomical Handbook of Tables), Persian, $315\{16-17\}$. See $\rightarrow$ 'Alī al-Qūshjī, Part I.

[184] 1.1b. Same as preceding, $316\{1-2\}$.

[185] 1.2. [Mīrim Çelebī] Sharh-i Zïj-i Ulugh Beg (Commentary of Ulugh Beg's Astronomical Handbook of Tables), Persian, 1499, autograph, 315 \{17-18\}. See $\rightarrow$ Mīrim Çelebī. MANUSCRIPT: SK Ayasofya 2697 .

AL-'URḌ̂, Mu’ayyad al-Dīn al-'Āmirī al-Dimashqī (d. ca. 1266)

[186] 1. R. al-'amal bi-al-kura [al-kämila] (Treatise on Using the Sphere), Arabic, $320\{13\}$. Bound with al-Ṣuffi's K. al-'amal bi-al-usțurlāb. MANUSCRIPT: This codex should be the copy now housed as TSMK A. 3491 (Karatay: A 7047).

[187] 2a. R. fi kayfyyyat al-arșād (Treatise on the Method of Observations), Arabic, 1262-74, $323\{3\}$. Bound in a miscellaneous volume containing $R$. fi kayfiyyat 'amal ālāt al-rașad wa-kayfyyat istimālihā. MANUSCRIPT: This codex (2a) should be the copy now housed as SK Ayasofya 2673 . EDITION: Sevim Tekeli, “Al-Urdi'nin 'Risalet-ün fi Keyfiyet-il-Ersad' Adlı Makalesi,” Araştırma 8 (1970): 1-169.

[188] 2b. Same as preceding, Arabic, $329\{12\}$. Bound with Ibn al-Haytham's commentary on Ptolemy's Almagest and another commentary on the same work. MANUSCRIPT: TSMK A. 3329 (Karatay: A 7140).

[189] 2c. Same as preceding, $118\{17-18\}$. Bound with R. al-usturlāb, R. al-'amal bi-dhāt al-halaq, and al-Q̣āshānī's K. al-ișțilāhāt fì al-tașawwuf. [Catalogued under Kutub al-tașawwuf, etc.]

AL-WĀSIṬī, Ḥ̂ĀMID B. 'ALĪ (fl. ca. 950)

[190] 1. R. fì al-'amal bi-al-usturlāb al-kurī (Treatise on Using the Spherical Astrolabe), $317\{11-13\}$. Bound with al-Șūfìs K. al-'amal bi-al-usțurlāb. MANUSCRIPT: TSMK A. 3509 (Karatay: A 7045). EDITION: Kitābān fíal-'amal bi-al-asturlāb (Two Books on the Use of the Astrolabe), ed. Fuat Sezgin (Frankfurt: Institut für Geschichte der Arabisch-Islamischen Wissenschaften, 1986). [Text 1: Kitāb al-'amal bi-l-asturlāb in 402 chapters, facsimile of TSMK A. 3509. Text 2: Risāla fi'l-'amal bi-l-asțurlāb in 170 chapters, facsimile of SK Ayasofya 2642.]

\section{ANONYMOUS/UNIDENTIFIED AUTHORS}

[191] 1. $K . z \bar{y}$ (Book of Astronomical Handbook of Tables), $314\{2\}$. Bound with a treatise on how to calculate the ascendant. 
[192] 2. R.fíal-țālicwa-aḥkām al-nujūm (Treatise on the Ascendant and Astrological Judgments), 314 $\{2-3\}$. Bound with an anonymous $z \bar{y}$.

[193] 3. K. țălic al-waqt (Book on Calculating the Ascendant of the Time), $316\{19\}-317\{1\}$. Bound with an anonymous treatise on geomancy and Kūshyār's Mujmal al-ușūl.

[194] 4a. Țälici i wilādat-i Mehemmed Khān b. Murād Khān (The Birth Horoscope of Mehmed II, son of Murad II), Persian, 1451, 321 \{9-11\}. MANUSCRIPT: Beyazit Library Beyazit 4619. ${ }^{18}$

[195] 4b. "R. fì wilādat-i Sulțān Mehemmed Khān b. Sulțān Murād Khān," $323\{12-13\}$.

[196] 5. R. wilādat-i Cem b. Mehemmed Khān (The Birth Horoscope of Cem Sultan, son of Sultan Mehmed II), $317\{4-5\}$.

[197] 6. R. țălic-i Sulțān Bāyezīd Khān (The Horoscope of Sultan Bayezid II), $27\{2-3\}$. Bound with $R$. fi al-handasa and R. fi al-tafsìr. [Catalogued under Kutub al-tafāsìr wa-kutub 'ilm al-qirā'a.]

[198] 7. R. wilādat-i Shāh-zādah-i a'zam-i Mehemmed b. Sulțān al-Salāțin Sulțān Bāyezīd Khān (The Birth Horoscope of the Great Prince Mehmed, son of Sultan Bayezid II), $321\left\{5^{-7}\right\}$.

[199] 8. R. ahkām al-mawālìd (Treatise on the Judgments of the Births), $160\{8-9\}$. Bound with Sharh al-mukhtașar fi ilm al-tashrịh min qibal al-țibb. [Catalogued under al-Kutub al-țibbiyya.]

[200] 9a. R. fi ahkām al-nujūm (Treatise on the Judgments of the Stars), $323\{7\}$. Bound with $R$. $f i$ 'amal al-usturlāb and other treatises. MANUSCRIPT: This particular book (9a) should be the copy now housed as SK Ayasofya $2672 .^{19}$

[201] 9b. Same as preceding, language specified as Persian, $322\{9-10\}$.

[202] 9c. Same as preceding, $324\{13\}$. Bound with $R$. min qibal al-nujūm, K. al-shajara wa-al-thamara, R. al-wafq, and K. al-ṣibyān fì al-lugha.

[203] 9d. "R.fí 'ilm ahkām al-nujūm," $324\{16\}$. Bound with Ibn Sīnā’s K. fíal-manțiq wa-al-ḥikma alfalsafiyya, al-Ṭūsi's Zubdat al-idrāk, and several other texts.

[204] 10. al-Mukhtār min kutub al-ikhtiyārāt al-falakiyya (Compilation on the Selection of the Propitious Times for Various Acts and Affairs), Arabic, $316\left\{15^{-16}\right\}$.

[205] 11. Mujmal al-ikhtiyārāt (Epitome of the Elections), $318\{10\}$.

[206] 12. Bustān al-hikma fì ikhtiyārāt al-nujūm (The Garden of Wisdom on Astrological Elections), $320\{9-10\}$.

[207] 13. K. al-ikhtiyārāt bi-al-'arabiyya al-manzūma fìahkām al-nujūm (Book on Elections in Verse), Arabic, $320\{18-19\}$.

[208] 14. K. ușūl al-malāḥim (Book on the Principles of Weather Prognostications), $317\{1-2\}$. Bound with Kūshyār's Mujmal al-ușūl.

[209] 15. K. al-malhama al-turkiyya min qibal al-nujūm (The Book of Weather Prognostications), Turkish, 98 \{18\}. Bound with Quṭb al-Dīnzāde's Muqaddima, Dīwān 'Āshiq, Gulshan-i Rāz, Khurshīdnāma, and Khusraw u shīrin. [Catalogued under Kutub al-fiqh wa-kutub manāqib ala'imma.]

[210] 16. R. malḥamat al-sana allati allafahā Dhū-al-Qarnayn fí ạ̣kām al-sana min qibal al-nujūm (Treatise on Annual Weather Prognostications Attributed to Dhū-al-Qarnayn [Alexander the Great]), 132 \{10-11\}. Bound with K. al-fanā' fi al-mushāhada, K. al-qism al-ilāhī, K. inshä' aljadāwil, R. al-amr al-marbūț, K. al-'azama, K. maqam al-qurba, K. mafātīh al-ghayb, R. fì sharh al-alfāz, K. al-yā', K. fì sharh al-asmā’ al-ḥusnā, K. hilyat al-abdāl, K. al-tadbīrāt al-ilāhiyya, R. ashkāl dawā'ir al-'awālim, and some of the treatises of Muhyī al-Dīn al-'Arabī on Sufism. [Catalogued under Kutub al-tașawwufwa-kutub al-nașāih., etc.]

[211] 17a. R. fi samt al-qibla (Treatise on the Azimuth of the Qibla), $313\{13\}$.

[212] 17b. Same as preceding, $323\{9\}$. 
[213] 17c. Same as preceding, $85\{19\}$. Bound with al-Qaramānī's Hāshiyat Șadr al-Sharī'a. [Catalogued under Kutub al-figh wa-kutub manāqib al-a'imma.]

[214] 18a. R. al-usțurlāb (Treatise on the Astrolabe), $118\{17\}$. Bound with R. márifat kayfiyyat al-irșād, R. al-'amal bi-dhāt al-ḥalaq, and al-Qāshānī's K. al-iștilāhạât fì al-taṣawwuf. [Catalogued under Kutub al-tașawwufwa-kutub al-nașāih h, etc.]

[215] 18b. Same as preceding, $317\{8-9\}$. Bound with K. arba'maqālāt fì ahkām al-nujūm.

[216] 18c. Same as preceding, $320\{1\}$. Bound with Sharaf al-Dīn al-Ṭūsī's K. fì ma'rifat al-usțurlāb al-musațtah, al-Ṣūfi's K. fìal-'amal bi-al-kura, Qusțā b. Lūqā’s K. fíal-'amal bi-al-kura, al-Bīrūnī's K. $f_{\bar{\imath}}$ istī' $\bar{a} b$ al-wujūh, and an anonymous treatise on the spherical astrolabe. MANUSCRIPT: According to the Islamic Scientific Manuscript Initiative database (https://ismi.mpiwg-berlin. mpg.de/), this codex might be TSMK A. 3505 (Karatay: A 7046). ${ }^{20}$

[217] 18d. Same as preceding, 320 \{7\}. Bound with Qusțā b. Lūqā's R. al-'amal bi-al-kura al-falakiyya, an anonymous treatise on the spherical astrolabe, and R. al-'amal bi-al-rub'al-mawdī' fihi almuqantarāt. MANUSCRIPT: This codex (18d) should be the copy now housed as SK Ayasofya 2638 .

[218] 18e. Same as preceding, language specified as Persian, $321\{14\}$.

[219] 18f. "R. fì ilm al-usturläb," language specified as Arabic, $322\{1-2\}$.

[220] 18g. "R. al-'amal al-usțurlāb," $323\{7\}$. Bound with R. fi ahkām al-nujūm and other treatises.

[221] 18h. "K. fi al-usțurläb fì 'ilm al-nujūm," $62\{15\}$. Bound with K. anwār al-afkārfì al-hikma al-falsafiyya, Sharh khuṭba Ibn Sinnā, al-Ghazālī's K. tahāfut al-falāsifa, K. lawāmi'al-bayyinātfì sharh al-asmä’ wa-al-șifät. [Catalogued under kutub ilm ușül al-dìn.]

[222] 19a. R. fì kayfiyyat al-'amal bi-al-usturlāb al-kurī (Treatise on Using the Spherical Astrolabe), $318\{9\}$. Bound with an anonymous commentary of al-Ṭūsìs Bisst bāb. MANUSCRIPT: This codex (19a) should be the copy now housed as SK Ayasofya 2642. EDITION: Kitābān fi al-'amal bi-alasturlāb (Two Books on the Use of the Astrolabe), ed. Fuat Sezgin (Frankfurt: Institut für Geschichte der Arabisch-Islamischen Wissenschaften, 1986). [Text 1: Kitāb al-'amal bi-l-asțurlāb in 402 chapters, facsimile of TSMK A. 3509. Text 2: Risāla fíl-'amal bi-l-asțurlāb in 170 chapters, facsimile of SK Ayasofya 2642.]

[223] 19b. Same as preceding, $319\{15\}$.

[224] 19c. "K. fí al-'amal bi-al-usțrlāb al-kurī," 319 \{19\}. Bound with Sharaf al-Dīn al-Ṭūsì's K. fi ma'rifat al-usțurlāb al-musațtah, al-Ṣūfi's K. fì al-'amal bi-al-kura, Qusțā b. Lūqā's K. fì al-'amal bi-al-kura, al-Bīrūnī's $K$. fi istī āb al-wujūh, and an anonymous treatise on the astrolabe. MANUSCRIPT: According to the Islamic Scientific Manuscript Initiative database (https://ismi.mpiwg-berlin.mpg.de/), this codex is probably TSMK A. 3505 (Karatay: A 7046). ${ }^{21}$

[225] 19d. "R. al-usțrlāb al-kurī", 320 \{7\}. Bound with Qusțā b. Lūqā's R. al-'amal bi-al-kura al-falakiyya, an anonymous treatise on the astrolabe, and R. al-'amal bi-al-rub'al-mawd̄ ü fihi almuqanțarāt. MANUSCRIPT: This codex (19d) should be the copy now housed as SK Ayasofya 2638 .

[226] 20. R. al-M. al-ḥādì' 'ashara fì 'amal al-usțurlāb, $322\left\{15^{-16}\right\}$.

[227] 21. Tuhfa-ishāhīfima'rifat al-usțurläb (Royal Gift on the Knowledge of the Astrolabe), Persian, $363\{5\}$. Bound with Sharh al-Namaț al-tāsi' min al-Ishārāt, R. fi al-raml, al-Ṭūsì's Madkhal-i manzūm, Sharh al-qașida al-mansūba ilā Ibn Sīnāfíal-hikma. [Catalogued under kutub al-hikma al-islämiyya.]

[228] 22. R. al-usțurlāb al-musammā bi-al-Lubāb fíal-nujūm (Treatise on the Astrolabe, entitled The Quintessence on [the Knowledge about] the Astrolabe), Persian, 320 \{3\}. MANUSCRIPT: SK Ayasofya 2618, personal copy of Bayezid II. 
[229] 23a. R. fi al-rub'al-mujayyab (Treatise on the Sinical Quadrant), $318\{3\}$. Bound with al-Tuusis's R. bisst bāb, Sīfașl, and al-Mizzì's R. fì al-rub`al-dāira. MANUSCRIPT: SK Ayasofya 2621.

[230] 23b. Same as preceding, language specified as Arabic, $255\{11\}$. Bound with Nazm al-farā’id fi al-fiqh and R. fima'rifat șafhat al-muqanțarāt. [Catalogued under al-dawāwīn al-färisiyya.]

[231] 24. R. fi'amal al-șafina (Epistle on the Operation of the Tympan), 321 \{4\}. Bound in a volume containing R. al-'amal [bi-]al-usturlāb attributed to Kūshyār and other treatises. MANUSCRIPT: SK Ayasofya $2671 .^{22}$

[232] 25. Jadwal [...] țab'ahä burjahā (Table Showing the Qualities of Zodiac Signs), $322\{4-5\}$. Bound in a miscellaneous compilation of tables.

[233] 26. R. marifatal-irtifā'bi-ghayral-usțurläb (Treatise on Calculating the Altitude without Using the Astrolabe), Persian, $320\left\{5^{-6}\right\}$. MANUSCRIPT: SK Ayasofya 2627.

[234] 27. R. al-'amalbi-al-rub'al-mawdū'fihi al-muqanțarāt (Treatise on the Use of Almucantar), 320 \{7-8\}. Bound with Qusțā b. Lūqā's R. al-'amal bi-al-kura al-falakiyya, an anonymous treatise on the spherical astrolabe, and an anonymous treatise on the astrolabe. MANUSCRIPT: This codex (27) should be the copy now housed as SK Ayasofya 2638.

[235] 28. Khams rasāil fi al-'amal bi-al-rub' (Five Treatises on the Use of the Quadrant), $320\{11\}$. Bound with Qusțā b. Lūqā's R. fì al-'amal bi-al-kura dhät al-kursī.

[236] 29. R. bahth ažlāl al-maqāyīs min qibal al-nujüm (The Measure of Shadows), $321\{13\}$.

[237] 30. K. al-azmān wa-al-shuhür (The Book of Epochs and Months), 321 \{13-14\}.

[238] 31. R. fial-amal bi-ashal āla (A Short Work on the Operation of the Easiest Instrument Having to Do with the Planets), Persian, 1481-1512, $321\{19\}$. MANUSCRIPT: Princeton University Garrett Collection 75 [44b]. EDITION: E. S. Kennedy, The Planetary Equatorium of Jamshīd Ghiyāth al-Dīn al-Käshī (d. 1429), An Edition of the Anonymous Persian Manuscript 75 [44b] in the Garrett Collection at Princeton University (Princeton: Princeton University Press, 1960).

[239] 32. K.jadāwil al-tawārikh wa-al-nujüm (Tables on Chronology and [Position of the] Stars), 322 $\{1\}$.

[240] 33. Muntakhab k. anwār al-jawāhir fìmanāzil al-Qamar (Selections from the Book of the Illuminations of Jewels regarding the Lunar Mansions), $322\{17-18\}$. Bound with R. al-wafq and R. mukātabāt al-Shaykh Ṣadr al-Dīn al-Qunawì ma'a al-Nașir al-Ṭūsí.

[241] 34. Majmǘa min rasāillfíal-rub'(Collection of Treatises on the Quadrant), $323\{1\}$.

[242] 35. R. fì al-darajwa-al-daqāiq fi al-nujūm (Treatise on Degrees and Minutes), 323 \{10\}. Bound with R. fi al-hay'a and R. fìal-hisāb.

[243] 36. R. 'alā țarīq al-su'äl wa-al-jawāb fíal-nujūm (Treatise on [the science of] the Stars through Questions and Answers), 323 \{14-15\}. Bound with K. al-mi'a wa-al-ishrin fi hisāb al-darb and other treatises.

[244] 37. R. fì al-älat al-nujümiyya al-ghayr al-mashhūra (Treatise on a Little-Known Astronomical Instrument), Arabic, 323 \{17\}. MANUSCRIPT: TSMK A. 3487 (Karatay: A 7124).

[245] 38. K.jadwal 'uyyina fih ishuhür al-kabisa al-qamariyya bi-sinīha (Book of Tables in which Leap Years are Designated According to the Lunar Calendar), $324\{1\}$.

[246] 39. R. fial-'amal bi-al-basița al-zilliya (Treatise on the Use of the Instrument Measuring Shadows), $324\{2\}$.

[247] 40. R. min qibal al-nujüm (Treatise regarding [the science of] the Stars), $324\{12\}$. Bound with R. fi ahkām al-nujūm, K. al-shajara wa-al-thamara, R. al-wafq, and K. al-șibyān fíal-lugha.

[248] 41a. R. al-'amal bi-dhät al-halaq (Book on the Use of the Armillary Sphere), $328\{12\}$. 
[249] 41b. Same as preceding, $118\{17-18\}$. Bound with R. al-usțrlāb, R. ma'rifat kayfiyyat al-irșād, and al-Qāshān̄̄'s K. al-ișțilāhātf fì al-tașawwuf. [Catalogued under Kutub al-tașawwufwa-kutub al-nașāìh, etc.]

[250] 42. R. fi kayfiyyat 'amal ālāt al-rașad wa-kayfiyyat istimālihāa (Treatise on the Use of Instruments for Celestial Observation), $323\{3-4\}$. Bound in a miscellaneous volume containing al'Urḍī's R. fi kayfiyyat al-arșāẹ. MANUSCRIPT: This codex (42) should be the copy now housed as SK Ayasofya 2673 .

[251] 43. al-Qașidat al-gharrā̉ fi ḩarakāt al-aflāk (The Splendid Qasida on the Movements of the Orbs), Arabic, $331\{7\}$. MANUSCRIPT: SK Ayasofya 2666.

[252] 43.1 Sharh al-Qașïdatal-gharrä', $331\{6\}$.

[253] 44. R. făl al-kawākib (Treatise on Fortune-Telling Based on the Stars), $135\{12\}$. Bound with $K$. haqq al-yaqīn fì al-tașawwuf, K. gulshan-i rāz, K. kanz al-rumūz, Qașīdat Firdawsī, K. jam mukhtașar fì ilm al-arūd, K. fíal-șalāt, K. maqșad al-Aqșā fí al-tasawwuf, and arba' rasā’il. [Catalogued under kutub al-tașawwuf, etc.]

[254] 45. K. fimāyahtāju ilayhial-mutațabbibmin cilmal-nujüm fì al-țibb (Book on what the Physician Needs to Know about the Science of the Stars), $153\{6\}$. Bound with Hippocrates's K. al-fușūl, Muḥammad b. Zakariyyā's K. fì al-qülanj, K. al-lu’lu’at fì tadbìr al-șihha, K. al-khadar wa-sab'at 'ashar. [Catalogued under al-kutub al-tibbiyya.]

[255] 46. R. fima'rifat șafihat al-muqanțarāt (Epistle on the Knowledge of the Plate of Almucantar), Persian, $255\{10-11\}$. Bound with Nazm al-farä’id fi al-figh and R. al-rub' al-mujayyab. [Catalogued under al-dawāwìn al-fârisiyya.]

[256] 47. R. al-manzūma fì al-ahwāl al-falakiyya min qibal al-nujūm (Treatise in Verse on Celestial Influences), Persian, $257\left\{13^{-14}\right\}$. Bound with R. manzüma fí awșāalal-azhār. [Catalogued under al-Dawāwìn al-färisizya.]

[257] 48. R. fi ahkām al-khusūfwa-al-kusüfal-manzūma (Treatise in Verse on the Decrees of the Solar and Lunar Eclipse), language specified as Turkish, $263\{5\}$. [Catalogued under al-dawāwìn al-turkiyya, etc.]

[258] 49. R.jadāwil al-tawārīkh wa-ikhtiyārāt al-a'māl bi-hisāb ittișālāt al-qamar (Tables of Chronology and Elections on the Basis of the Moon's Positions vis-à-vis Other Planets), 310 \{9-10\}. Bound in a volume that contains Thalāth maqālāt min K. Ayran fi raf' al-ashyä al-thaqüla, R. al-dawā'ir al-mutaharrika min dhawātihā, R. 'amal al-sā'āt allatī tarmì bi-al-banādiq, K. alqirānāt wa-ittișālāt al-kawākib. [Catalogued under kutub 'ilm al-ta'bìr, etc.]

[259] 50. K. al-qirānātwa-ittișālātal-kawākib (Book of Conjunctions and Stellar Aspects), 310 \{10-11\}. Bound in a volume that contains Thalāth maqālāt min $K$. Ayran fì raf' al-ashyä al-thaqüla, $R$. al-dawā'ir al-mutaharrika min dhawātihā, R. 'amal al-sā'āt allatì tarmībi-al-banādiq, R.jadāwil al-tawārīkh wa-ikhtiyārāt al-a'māl bi-ḥisāb ittișālāt al-qamar. [Catalogued under kutub 'ilmalta'bir, etc.]

[260] R. jihād al-mulūk 'alā țarīqat ahkām al-nujūm, 311 \{6-7\}. Bound with al-Durr al-mațlūb fì sirr al-ghālib wa-al-maghlüb and $R$. fì al-kharazāt al-khams min al-jafr. [Catalogued under kutub 'ilmal-ta'bir, etc.] 


\section{PART TWO}

The Science of the Configuration [of the Heavens] ('ilm al-hay'a)

AL-ALĀNĪ, Yūsuf b. Mubārak (d. after 1334)

[261] 1. Turar al-mulakhkhașfial-hay'a (Commentary of Chagmīnìs Mulakhkhaṣ), Arabic, 1335, 330 $\{18-19\}$. See $\rightarrow$ al-Chagmīnī, 1.3. MANUSCRIPT: TSMK A. 3308 (Karatay: A 7060).

AL-ANDIQĀNī, Muhammad b. 'Umar (fl. fourteenth century)

[262] 1. Tarjamat Chaghminnì bi-al-färisiyya fì 'ilm al-hay'a (Persian Translation of Chagmīnī's Mulakhkhaș, Persian, 326 \{19\}. See $\rightarrow$ al-Chagminnī, 1(i). MANUSCRIPT: This codex should be the copy now housed as SK Ayasofya $2592 .{ }^{23}$

AL-BIṬRŪĪ, Nūr al-Dīn Abū Isḥāq Ibrāhīm b. Yūsuf (d. 1185)

[263] 1a. K. [murta'ish] fial-hay'a (Book of Trembling on Hay'a) [catalogued in the inventory as $K$. 'ajib fi al-hay'a], Arabic, $332\{14\}$. Bound with other anonymous treatises. MANUSCRIPT: TSMK A. 3302 (Karatay: A7055). EDITION: Bițrūjī, On the Principles of Astronomy: An Edition of the Arabic and Hebrew Versions with Translation, Analysis, and an Arabic-Hebrew-English Glossary, ed. Bernard Goldstein (New Haven: Yale University Press, 1971).

[264] 1b. Same as preceding, $332\{15\}$. Bound with other anonymous treatises.

AL-BUKHĀRĪ, Muḥammad Ibrāhīm b. Mubārakshāh Shams al-Dīn Mīrak (d. 1340)

[265] 1a. Sharh al-Tabșira (Commentary of al-Kharaqi’s Tabșira), Arabic, autograph, $328\{8-9\}$. See $\rightarrow$ al-Kharaqī, 1.1. MANUSCRIPT: SK Ayasofya 2582 .

[266] 1b. Same as preceding, bound with 1 .

AL-CHAGHMĪNĪ, Sharaf al-Dīn Maḥmūd b. Muhammad b. 'Umar (fl. first half of the thirteenth c.)

[267] 1a. al-Mulakhkhas fi al-hay'a al-basița (Epitome of Plain Theoretical Astronomy), Arabic, 61 \{12-13\}. Bound with al-Khayālī's K. hạshiyat sharh al-'aqā’id. [Catalogued under Kutub 'ilm ușūl al-dinn.] EDITION: Sally P. Ragep, Jaghminni’s Mulakhkhaș: An Islamic Introduction to Ptolemaic Astronomy (New York: Springer-Verlag, 2016).

[268] 1b. Same as preceding, $328\{10-11\}$. MANUSCRIPT: One of these two (1a and $1 \mathrm{~b}$ ) should be TSMK A. $335^{2}$ (Karatay 8744 ).

[269] 1c. Same as preceding, $328\{11\}$. MANUSCRIPT: These two codices (1b and 1c) may be the copies now housed as SK Ayasofya 2679 and TSMK A. 3352 (Karatay 8744).

[270] 1d. Same as preceding, $327\{10\}$. Bound with Matn ädäb al-bahth fì ilm al-jadal.

[271] 1e. Same as preceding, 331 \{4\}. Bound with al-Jurjānīs Sharh al-Mulakhkhaṣ. MANUSCRIPT: TSMK, A. 3296 (Karatay: A 7057).

[272] 1(i). [al-Andiqānī.] Tarjamat Chaghminnī bi-al-fārisiyya fì ‘ilm al-hay’a, Persian, $326\{19\}$. See $\rightarrow$ al- Andiqānī. MANUSCRIPT: This codex (1(i)) should be the copy now housed as SK Ayasofya $2592 .^{24}$

[273] 1(ii). [Ḥamza b. Hājj b. Sulaymān.] Same as preceding, Persian, $327\{8\}$. Bound with an anonymous Persian commentary of al-Chaghmīnī’s Mulakhkhaṣ. See $\rightarrow$ Ḥamza b. Hājj Sulaymān. MANUSCRIPT: This codex (1(ii)) should be the copy now housed as SK Ayasofya 2593.

[274] 1.1a. [al-Jurjānī.] Sharh al-Mulakhkhaș, Arabic, $331\{4-5\}$. Bound with al-Chaghmīnī's al-Mulakhkhaṣ. See $\rightarrow$ al-Jurjānī, 1, Part II. 
[275] 1.1b. Same as preceding, $326\{8\}$. MANUSCRIPT: This codex (1.1b) should be the copy now housed as SK Ayasofya 2651.

[276] 1.1c. Same as preceding, $327\{7-8\}$.

[277] 1.1d. Same as preceding, $328\{3\}$. MANUSCRIPT: One of the two codices (1.1c, 1.1d) should be the copy now housed as SK Ayasofya 2653.

[278] 1.1e. Same as preceding, 328 \{4\}. Bound with al-Jurjāni’s Hāshiyat sharh al-Ṭawālic (Supercommentary on al-Bayḍāwī's Rising Light from Far Horizons).

[279] 1.1f. Same as preceding, $3^{28}\left\{15^{-16}\right\}$. Bound with al-Turkmānī's commentary on al-Chaghmīnī's Mulakhkhaș.

[280] 1.1g. Same as preceding, $329\{3\}$. MANUSCRIPT: This codex (1.1g) should be the copy now housed as SK Ayasofya 2654.

[281] 1.1h. Same as preceding, $330\{19\}-331\{1\}$.

[282] 1.1(i). Turkish translation of al-Jurjānī's Sharh al-Mulakhkhaș, $329\{6\}$.

[283] 1.2a. [Qādīizāde al-Rūmī.] Sharh al-Mulakhkhaș, Arabic, 1412, 328 \{1-2\}. Bound with K. fíal-hay’a. See $\rightarrow$ Qādìizāde al-Rūmi, Part II.

[284] 1.2b. Same as preceding, $328\{2\}$.

[285] 1.2c. Same as preceding, $328\{12-13\}$.

[286] 1.2d. Same as preceding, $328\left\{13^{-14}\right\}$. Bound with R. al-ishq bi-al-fārisiyya and al-Nīsābūrì's R. al-Shamsiyya. MANUSCRIPT: This (1.2d) should be the copy now housed as SK Ayasofya 2659 .

[287] 1.2e. Same as preceding, $329\{2\}$.

[288] 1.2f. Same as preceding, $329\{16-17\}$.

[289] 1.2g. Same as preceding, $330\{10-11\}$. Bound with miscellaneous treatises.

[290] 1.2h. Same as preceding, $330\{14-15\}$.

[291] 1.2i. Same as preceding, $330\{16\}$.

[292] 1.2j. Same as preceding, $332\{6-7\}$. Bound with Qāḍizāde al-Rūmī's Sharh Ashkāl al-ta’sīs.

[293] 1.2.1. [al-Niksārī.] Hāshiyat sharh al-Chaghmin̄ī, Arabic, 326 \{15-16\}. See $\rightarrow$ al-Niksārī. MANUSCRIPT: SK Ayasofya 2656.

[294] 1.2.2. [al-Shirwānī.] Hāshiyat sharh Qādīzāade li-l-Chaghmīnī, $329\{1-2\}$. See $\rightarrow$ al-Shirwānī, Part II. MANUSCRIPT: TSMK A. 3294 (Karatay: A 7077). ${ }^{25}$

[295] 1.2.3. [Sinān Pasha.] Hāshiyat sharh Qādìzāde li-l-Chaghmīnī, $330\{15\}$. See $\rightarrow$ Sinān Pasha. MANUSCRIPT: TSMK A. 3299 (Karatay: A 7074). ${ }^{26}$

[296] 1.3. [al-Alānī.] Țurar al-mulakhkhas fíal-hay'a, Arabic, 1334, 330 \{18-19\}. See $\rightarrow$ al-Alānī. MANUSCRIPT: TSMK A. 3308 (Karatay: A 7060).

[297] 1.4a. [al-'Ubaydī.] Sharh al-mulakhkhaș, Arabic, $327\left\{3^{-4}\right\}$. Bound with al-'Ubaydī's Bayān al-Tadhkira. See $\rightarrow$ al-'Ubaydī. MANUSCRIPT: TSMK A. 3325 (Karatay: A 7058).

[298] 1.4b. Same as preceding, 316 \{13\}. Bound with K. al-hidāya fì al-hikma and al-Tūūsìs Sī fașl. MANUSCRIPT: SK Ayasofya 2474.

[299] 1.5 [al-Turkmānī.] Sharh k. al-Chaghminnī, Arabic, 328 \{16\}. Bound with al-Jurjānī's Sharh al-Mulakhkhaṣ. See $\rightarrow$ al-Turkmānī. MANUSCRIPT: SK Ayasofya 2653.

[300] 1.6 [Qarā Sinān.] Sharh al-Chaghmīnī, 326 \{2\}. See $\rightarrow$ Qarā Sinān.

[301] 1.7a. "Sharh al-Mulakhkhaș," Persian, 327 \{8\}. Bound with Ḥamza b. Hājj b. Sulaymān's Persian translation of al-Chaghmīnìs Mulakhkhaș. MANUSCRIPT: This codex (1.7a) should be the copy now housed as SK Ayasofya 2593.

[302] 1.7.1a. "Hāshiyat sharh al-Chaghminī," $325\{19\}-326\{1\}$.

[303] 1.7.1b. Same as preceding, $332\{8\}$. 
[304] 1.7.1c. Same as preceding, 327 \{18\}. MANUSCRIPT: These two codices (1.7.1b and 1.7.1c) should be the copies now housed as SK Ayasofya 2607 and 2608 .

[305] 1.7.1d. Same as preceding, $329\left\{13^{-14}\right\}$.

GHULĀM SINĀN (d. 1506)

[306] 1. Fath al-fathiyya fì sharh al-Fathiyya (Commentary on 'Alī al-Qūshjī's R. al-fathiyya), Arabic, 1485, $328\{10\}$. See $\rightarrow$ 'Alī al-Qūshjī, 1.1, Part II. MANUSCRIPT: This codex should be the copy now housed as TSMK A. 3291 (Karatay: A 7117).

ḤAMZA B. ḤĀJJ B. SULAYMĀN (fl. fifteenth century)

[307] 1. Tarjamat Chaghmīni bi-al-färisiyya (Persian translation of al-Chaghmīnī's Mulakhkhaṣ), Persian, $327\{8\}$. See $\rightarrow$ al-Chagmīnī, 1 (ii). Bound with an anonymous Persian commentary of al-Chaghmīni’s Mulakhkhas. MANUSCRIPT: This codex should be the copy now housed as SK Ayasofya 2593 .

IBN AL-HAYTHAM, Abū 'Alī al-Ḥasan b. al-Ḥasan (d. ca. 1040)

See also Ibn al-Haytham in Part One ('ilm al-nujūm) and Part Four ('ilm al-handasa).

[308] 1. Hall shukükfi k. al-Majisți (Solution of Difficulties in the Almagest), Arabic, $323\{2\}$. Bound with Sharh Sī faṣl.

[309] 2. Sharh k. Majisțī Bațlamyūs (A Commentary of Ptolemy's Almagest), Arabic, 329 \{11\}. Bound with another commentary on Almagest and al-'Urḍi’s Kayfiyyat al-arșäd. MANUSCRIPT:TSMK A. 3329 (Karatay: A 7140).

AL-KHARAQĪ, 'Abd al-Jabbār (d. 1158)

[310] 1a. al-Tabșirā fí 'ilmal-hay'a (Conspectus of the Science of the Configurations of the Heavens), Arabic, 1132-33, 324 \{6-7\}. Bound with al-Ṭabarī's Firdaws al-ḥikma and 'Alī b. ‘̄̄sā al-Usțurlābī's R. fi al-usturlāb.

[311] 1 b. Same as preceding, $328\{6\}$.

[312] 1c. Same as preceding, $329\{5\}$.

[313] 1d. Same as preceding, $329\{13\}$. MANUSCRIPT: The last three codices (1b, 1c, 1d) should be the copies now housed as SK Ayasofya 2578, Ayasofya 2579, and Ayasofya 2581.

[314] 1.1a. [al-Bukhārī, Mubārakshāh.] Sharh al-Tabṣira, Arabic, autograph, $328\{8-9\}$. See $\rightarrow$ alBukhārī, Part II. MANUSCRIPT: SK Ayasofya 2582.

[315] 1.1b. Same as preceding, bound with 1.1a.

[316] 2. 'Umda Khwārazmshāhī, Persian, thirteenth century, $328\{17\}$.

AL-JĀJARAMĪ, Mu’ayyad Muhammad (fl. thirteenth century)

[317] 1. K. fașs al-khātam fì hay'at al-'älam (The Ring Stone on the Configuration of the World), Persian, 326 \{1-2\}. MANUSCRIPT: TSMK A. 3337 (Karatay: F 227).

AL-JURJĀNĪ AL-SAYYID AL-SHARĪF, 'Alī b. Muḥammad (d. 1413)

[318] 1a. Sharhal-Mulakhkhaș (Commentary on al-Chaghmīn̄’s Epitome), Arabic, $331\{4-5\}$. Bound with al-Chaghmīnī's al-Mulakhkhaṣ. See $\rightarrow$ al-Chagmīnī, 1.1.

[319] 1b. Same as preceding, $326\{8\}$. MANUSCRIPT: This codex (1b) should be the copy now housed as SK Ayasofya 2651.

[320] 1c. Same as preceding, $327\{7-8\}$. 
[321] 1d. Same as preceding, $328\{3\}$. MANUSCRIPT: One of the two codices (1c, 1d) should be the copy now housed as SK Ayasofya 2653 .

[322] 1e. Same as preceding, 328 \{4\}. Bound with al-Jurjānī's Hāshiyat sharh al-Tawālic (Supercommentary on al-Bayḍāwī's Rising Light from Far Horizons).

[323] If. Same as preceding, $3^{28}\left\{15^{-16}\right\}$. Bound with al-Turkmānī's commentary on al-Chaghmīn̄̄s Mulakhkhaș.

[324] 1g. Same as preceding, $329\{3\}$. MANUSCRIPT: This codex (1g) should be the copy now housed as SK Ayasofya 2654 .

[325] 1h. Same as preceding, $330\{19\}-331\{1\}$.

[326] 1(i). Turkish translation of al-Jurjānīs Sharh al-Mulakhkhaș, $329\{6\}$.

[327] 2. Sharh al-Tadhkira (Commentary of Țūsīs Memoir), Arabic, 1409. See $\rightarrow$ al-Ṭūsi, 2.4-2.10, Part II. ${ }^{27}$ MANUSCRIPT: This codex should be the copy now housed as TSMK A. 3320 (Karatay: A 7091).

AL-MAS'ŪDĪ, Sharaf al-Dīn Muḥammad b. Mas'ūd (fl. thirteenth century)

[328] 1a. K. jahān-dānish (Book of Knowledge of the World), Persian translation of his al-Kifäya fi 'ilm hay'at al-'ālam, 1246, 325 \{17-18\}. EDITION: Jahān-i dānish, ed. Khalīl Akhavān Zanjānī (Tehran: Mīrās̄-i Maktūb, 2003).

[329] 1b. Same as preceding, $331\{12-13\}$. MANUSCRIPT: One of the two codices (1a, $1 \mathrm{~b})$ should be the copy now housed as SK Ayasofya 2601.

[330] 1c. Same as preceding, $327\{1\}$. MANUSCRIPT: This codex (1c) should be the copy now housed as SK Ayasofya 2602.

[331] 1d. Same as preceding, 328 \{6-7\}. Bound with R.fäl-i Qur'ān, R. färisiyya fímunāzarat Baghdād wa-Ișfahān, and R. munsha'āt al-șāhib al-marhüm.

AL-NIKSĀRĪ, Muhyī al-Dīn Muhammad b. Ibrāhīm b. Ḥasan al-Rūmī (d. 1495)

[332] 1. Huashiyat sharh al-Chaghmīnī, Arabic, $3_{2}^{26}\left\{15^{-16\}}\right.$. See $\rightarrow$ al-Chagmīnī, 1.2.1; Qāḍīzāde al-Rūmi, 1.1. MANUSCRIPT: SK Ayasofya 2656.

AL-NīsĀBūRĪ, al-Ḥasan b. Muḥammad b. al-Ḥusayn Niẓām al-Dīn al-A'raj (d. ca. 1329-30)

See also al-Nīsābūrī in Part One ('ilm al-nujūm) and Part Three ('ilm al-hisāb).

[333] 1a. Tawdīh (or Sharh) al-tadhkira (Elucidation of the Memoir), Arabic, 1311, autograph, 329 $\{9-10\}$. See $\rightarrow$ al-Ṭūsī, 2.1, Part II.

[334] 1b. Same as preceding, $327\{2-3\}$. Bound with al-Ṭūsìs K. al-tadhkira fí 'ilm al-hay'a.

[335] 1c. Same as preceding, $327\{19\}$. Bound with al-Ṭūsis's K. al-tadhkira fí 'ilm al-hay'a. MANUSCRIPT: One of the two codices $(\mathrm{lb}, 1 \mathrm{c})$ should be the copy now housed as SK Ayasofya 2589.

[336] 1d. Same as preceding [catalogued in the inventory as Tawdịh al-tadhkira], $327\{11\}$.

[337] 1e. Same as preceding [catalogued in the inventory as Sharh al-tadhkira], $328\{5\}$. MANUSCRIPT: This codex (1e) should be the copy now housed as SK Ayasofya 2646.

[338] if. Same as preceding [catalogued in the inventory as Sharh al-tadhkira al-musammā bi-tawdīh al-tadhkira $], 330\{3-4\}$.

[339] 1g. Same as preceding, $330\{4-5\}$. MANUSCRIPT: One of the two codices (If, Ig) should be the copy now housed as SK Ayasofya 2647.

[340] 2. Tafsìr [or Sharh ] al-Tahrīr al-Majisțī (Exegesis of al-Ṭūsìs Recension of the Almagest), Arabic, $1305,329\{14-15\}$. 
QĀḌ̂̄ZĀDE AL-RŪMĪ, Șalāḥ al-Dīn Mūsā b. Muhammad b. Maḥmūd al-Rūmī (d. after 1440)

See also Qāạīzāde al-Rūmī in Part Four ('ilm al-handasa).

[341] 1a. Sharhal-Mulakhkhaș, Arabic, 1412, 328 \{1-2\}. Bound with K. fi al-hay'a. See $\rightarrow$ al-Chaghmīnī, 1.2 .

[342] 1b. Same as preceding, $328\{2\}$.

[343] 1c. Same as preceding, $328\{12-13\}$.

[344] 1d. Same as preceding, $328\left\{13^{-14}\right\}$. Bound with R. al-ishq bi-al-färisiyya and al-Nīsābūrī's R. al-Shamsiyya. MANUSCRIPT: This codex (1d) should be the copy now housed as SK Ayasofya 2659 .

[345] 1e. Same as preceding, $329\{2\}$.

[346] If. Same as preceding, $329\{16-17\}$.

[347] 1g. Same as preceding, $330\{10-11\}$. Bound with miscellaneous treatises.

[348] ih. Same as preceding, $330\{14-15\}$.

[349] 1i. Same as preceding, $330\{16\}$.

[350] ij. Same as preceding, $33^{2}\{6-7\}$. Bound with Qāḍīzāde al-Rūmī's Sharh Ashkāl al-ta’siss.

[351] 1.1. [al-Niksārī.] Hāshiyat sharh al-Chaghmīn̄i, Arabic, 326 \{15-16\}. See $\rightarrow$ al-Niksārī. MANUSCRIPT: SK Ayasofya 2656.

[352] 1.2. [al-Shirwānī.] Hāshiyat sharh Qā dịzāde li-l-Chaghmin̄ī, $329\{1-2\}$. See $\rightarrow$ al-Shirwānī, Part II. MANUSCRIPT: TSMK A. 3294 (Karatay: A 7077). ${ }^{28}$

[353] 1.3. [Sinān Pasha.] Same as preceding, $330\{15\}$. See $\rightarrow$ Sinān Pasha. MANUSCRIPT: TSMK A. 3299 (Karatay: A 7074$)^{29}$

QARĀ SINĀN (d. ca. 1480-81)

[354] 1. Sharhal-Chaghmīnī (Commentary on Chagmīnī's Mulakhkhas ), $326\{2\}$. See $\rightarrow$ al-Caghmīnī, 1.6.

AL-QŪSHJĪ, Abū al-Qāsim 'Alā' al-Dīn 'Alī b. Muḥammad (d. 1474)

See also al-Qūshjī in Part One ('ilm al-nujūm) and Part Three ('ilm al-hisāb).

[355] 1a. R. al-fathiyya fi 'ilm al-hay'a, Arabic, 1473, $327\{9\}$.

[356] 1b. Same as preceding, $33^{2}\{11\}$. Bound with al-Qūshjī's R. al-Muhammadiyya. MANUSCRIPT: This codex ( $(\mathrm{b})$ should be the copy now housed as SK Ayasofya 2733 .

[357] 1c. Same as preceding, 151 \{18-19\}. Bound with al-Nīsābūrīs R. fi al-țibb al-nabawī, al-Fanārì's Sharh İsāghūjī, 'Alī al-Qūshjī's R. muhammadiyya. [Catalogued under al-kutub al-țibbiyya.]

[358] 1.1. [Ghulām Sinān.] Fath al-fathiyya fi sharh al-Fathiyya, Arabic, 1485, $328\{10\}$. See $\rightarrow$ Ghulām Sinān. MANUSCRIPT: This codex (1.1) should be the copy now housed as TSMK A. 3291 (Karatay: A 7117).

[359] 2a. R. dar 'ilm al-hay'a, Persian, 1458, 327 \{11-12\}. Bound with a treatise in Persian on Arithmetic and Sharh Ashkālal-ta'sīs. MANUSCRIPT: This codex (2a) should be the copy now housed as SK Ayasofya 2640.

[36o] 2b. Same as preceding, $331\{5\}$. MANUSCRIPT: This codex (2b) should be the copy now housed as SK Ayasofya 2639 .

[361] 3. Sharh al-Tuhfa al-shāhiyya, Arabic, autograph. $33^{2}$ \{5-6\}. See $\rightarrow$ al-Shīrāzī, 3.1, in Part II. MANUSCRIPT: This codex might be the copy now housed as SK Ayasofya 2643. 
AL-SĀLĀR, 'Alī b. Faḍl Allāh Ḥusām al-Dīn (fl. ca. mid-eleventh century)

[362] 1. K.jämi'al-qawānīn [fi] 'ilmal-hay'a (Book Comprising the Rules of the Science of Hay'a), 318 $\left\{13^{-14}\right\}$. Bound with other treatises on the study of heavens and other topics. MANUSCRIPT: TSMK A. 3342 (Karatay: A 7141). ${ }^{30}$

SINĀN PASHA, Sinān al-Dīn Yūsuf b. Khị̣r Beg b. Jalāl al-Dīn ‘Ārif (d. 1486).

[363] 1. Hāshiyat sharh al-Mulakhkhaṣ, Arabic, $330\{15\}$. See $\rightarrow$ al-Chaghmīnī, 1.2.3; Qāạīzāde al-Rūmī, 1.3. MANUSCRIPT: TSMK A. 3299 (Karatay: A 7074). ${ }^{31}$

AL-SHĪRĀZĪ, Quṭb al-Dīn Maḥmūd b. Mas'ūd b. Muṣlị̣ (d. 1311)

See also al-Shīrāzī in Part Four ('ilm al-handasa)

[364] 1a. Nihāyat al-idrākfì dirāyat al-aflāk (The Utmost Attainment in Comprehending the Orbs), Arabic, 1281, $325\{16\}$.

[365] 1b. Same as preceding, $326\{10-11\}$. Bound with $R$. 'alä al-haraka al-dahraja (Commentary of the Treatise on the Motion of Rolling). MANUSCRIPT: This codex (lb) should be the copy now housed as TSMK A. 3336 (Karatay: A 7101).

[366] 1c. Same as preceding, $326\left\{13^{-14}\right\}$. Bound with al-Ṭusì's K. al-Tadhkirat. MANUSCRIPT: This codex (1c) should be the copy now housed as TSMK A. 3333 (Karatay: A 7082).

[367] 1d. Same as preceding, $326\left\{14^{-15}\right\}$.

[368] 1e. Same as preceding, $327\left\{5^{-6}\right\}$.

[369] 2. R. fi alā al-haraka al-dahraja (Treatise on the Motion of Rolling) [catalogued in the inventory as Sharh al-R. fi alā al-haraka al-dahraja], Arabic, 326 \{11-12\}. Bound with al-Shīrāzī's Nihāyat al-idrāk. MANUSCRIPT: This codex should be the copy now housed as TSMK A. 3336 (Karatay: A 7101).

[370] 3a. K. al-tuhfa al-shähiyya (The Royal Gift regarding the Knowledge of the Configuration of the Heavens), Arabic, 1295, $325\{19\}$.

[371] 3b. Same as preceding, $330\{1\}$.

[372] 3c. Same as preceding, $330\{2\}$.

[373] 3d. Same as preceding, $330\{17\}$.

[374] 3e. Same as preceding, $33^{1}\{2\}$. MANUSCRIPT: One of the five codices $(3 \mathrm{a}-3 \mathrm{e})$ should be the copy now housed as SK Ayasofya 2585.

[375] 3f. Same as preceding [catalogued in the inventory as K. al-tuhfa al-shähiyya li-al-Quṭb alShīrāaī, $330\{2-3\}$.

[376] 3g. Same as preceding, language specified as Arabic, $330\{12\}$. MANUSCRIPT: This codex (3g) should be the copy now housed as SK Ayasofya 2587.

[377] 3.1a. ['Alī al-Qūshjī.] Sharh al-tuhfa al-shāhiyya, Arabic, autograph, $33^{2}\left\{5^{-6}\right\}$. See $\rightarrow$ al-Qūshjī, 3, Part II. MANUSCRIPT: This codex (3.1a) might be the copy now housed as SK Ayasofya 2643 .

[378] 3.2. "Sharh al-Tuhfa al-shāhiyya," $330\{16-17\}$.

[379] 3.3. Same as preceding, $332\{5\}$.

[380] 3.4. "Hawāshī al-Tuhfa al-shāhiyya," $331\{3-4\}$.

[381] 4a. Fa'alta fa-là talum (You Have Done It, So Do Not Condemn), Arabic, 1300, $326\{18-19\}$. See $\rightarrow$ al-Ṭūsī, 2.2, Part II. MANUSCRIPT: TSMK A. 3338 (Karatay: A 7094).

[382] 4b. Same as preceding, $327\{1-2\}$. MANUSCRIPT: This codex (4b) should be the copy now housed as SK Ayasofya 2668. 
[383] 5. Ikhtiyārāt-i Muzaffariyya (The Muzaffarid Elections), Persian, 1282, $332\{1\}$. Bound with an anonymous astronomical epitome and al-Ṭūsı̄’s $R$. Mu ìnìya. MANUSCRIPT: TSMK A. 3310 (Karatay: F 233).

AL-SHIRWĀNĪ, Fatḥallāh b. Abū Yazīd b. 'Abd al-'Azīz b. Ibrāhīm al-Shābarānī (d. 1486)

See also al-Shirwānī in Part Five ('ilm al-mūsīqù).

[384] 1. Hāshiyat sharh Qādīzāde li-l-Chaghmīnī, Arabic, 1473, $329\{1-2\}$. See $\rightarrow$ al-Chaghmīnī, 1.2.2; Qāọīzāde al-Rūmī, 1.2. MANUSCRIPT: TSMK A. 3294 (Karatay: A 7077). ${ }^{32}$

[385] 2. Sharh al-Tadhkira, Arabic, 1475. See $\rightarrow$ al-Ṭūsi, 2.4-2.10, Part II. ${ }^{33}$ MANUSCRIPT: This codex should be TSMK, A. 3314 (Karatay: A 7093).

THĀBIT B. QURRA (d. 901)

[386] 1. Kfi ta'liffal-nisab (Book on the Composition of Ratios), Arabic, $329\{17\}$. Bound with Thābit b. Qurra's R. fial-shakl al-qațāa (Treatise on the Secant Figure) and a commentary on the preceding work. EDITION: Pascal Crouzet, "Thābit ibn Qurra et la composition des rapports. Texte et traduction: Livre sur la composition des rapports," in Thābit ibn Qurra: Science and Philosophy in Ninth-Century Baghdad, ed. Roshdi Rashed (Berlin: Walter de Gruyter, 2009): 391-535.

[387] 2. R. fíal-shakl al-mulaqqab bi-al-qațtā'min K. al-Majisțī (On the Figure Called the Secant from the Almagest), Arabic, $329\{18-19\}$. Bound with Thābit b. Qurra's K. fi ta'lif al-nisab and a commentary on R. fi al-shakl al-qațtā̄ . EDITION: Hélène Bellosta, "Le traité de Thābit ibn Qurra sur La figure secteur. Traduction: Sur la figure secteur," in Thābit ibn Qurra: Science and Philosophy in Ninth-Century Baghdad, ed. Roshdi Rashed (Berlin: Walter de Gruyter, 2009): 335-90.

[388] 2.1. "Sharh al-shakl al-mulaqqab bi-al-qațtā"," $329\{17-18\}$. Bound with Thābit b. Qurra's K. fi ta'lïf al-nisab and R. fi al-shakl al-qațțā.

AL-TURKMĀNĪ, Kamāl al-Dīn (d. 1357)

[389] 1. Sharh k. al-Chaghmin̄i (Commentary on al-Chaghmīnī's Mulakhkhaș), Arabic, 1354, $328\{16\}$. Bound with al-Jurjānī’s Sharḥ al-Mulakhkhaṣ. See $\rightarrow$ al-Chaghmīnī, 1.5; al-Jurjānī, 1. MANUSCRIPT: SK Ayasofya 2653 .

AL-ṬŪSĪ, Nașīr al-Dīn Abū Ja far Muḥammad b. Muḥammad (d. 1274)

See also al-Ṭūsī in Part One ('ilm al-nujūm), Part Three ('ilm al-ḥisāb), and Part Four ('ilm al-handasa).

[39o] 1a. R. Mu ìniyya, Persian, 1235, 326 \{16\}. Bound with al-Ṭūsī's Sharh-i Mu îniyya and the Zubdah$i$ hay'a. MANUSCRIPT: This codex (1a) should be the copy now housed as SK Ayasofya 2670. EDITION: al-Rișāla al-mu'īn̄ya, facs. ed. of Persian manuscript with introduction by Muhammad Taqī Dānishpazhūh (Tehran: Chāpkhānah-i Dānishgāh-i Tihrān, 1956).

[391] 1b. Same as preceding, 332 \{1-2\}. Bound with al-Shīrāzì's Ikhtiyārāt-i Muzaffariyya and an anonymous astronomical epitome.

[392] 1c. Same as preceding, $332\{4\}$.

[393] 1.1. [al-Ṭūīi Sharh-i Mu'iniyya, also known as Hall-i mushkilät-i Mu'ìniyya (A Solution to the Problems of the Mu'iniyya), 1245, Persian, 326 \{16-17\}. Bound with al-Ṭūsìs R. Mu'iniyya and Zubdat al-idrāk. MANUSCRIPT: This codex (1.1) should be the copy now housed as SK Ayasofya 2670. EDITION: Hall mushkilät-i mu ìñya, facs. ed. of Persian manuscript with introduction by Muḥammad Taqī Dānishpazhūh (Tehran: Chāpkhāna-i Dānishgāh-i Tihrān, 1956).

[394] 2a. K. al-Tadhkira fí 'ilm al-hay'a (Memoir on Astronomy), Arabic, 1261 [the year Marāgha version was completed], $3^{26}$ \{12\}. EDITION: Jamil Ragep, Nașīr Al-Dīn Al-Ṭūsī's Memoir on As- 
tronomy = Al-Tadhkira Fī 'ilm Al-Hay'a, 2 vols. (New York: Springer-Verlag, 1993). MANUSCRIPT: This codex (2a) might be TSMK A. 3317 (Karatay: 7081).

[395] 2b. Same as preceding, $326\{13\}$. Bound with al-Shīrāzī's K. nihāyat al-idrāk. MANUSCRIPT: This codex (2b) should be the copy now housed as TSMK A. 3333 (Karatay: A 7082).

[396] 2c. Same as preceding, 327 \{2\}. Bound with al-Nīsābūrīs Tawdịh (or Sharh) al-tadhkira.

[397] 2d. Same as preceding, 327 \{19\}. Bound with al-Nīsābūrī's Taw dịh (or Sharh ) al-tadhkira. MANUSCRIPT: One of these two codices ( $2 \mathrm{c}$ and $2 \mathrm{~d}$ ) should be the copy now housed as SK Ayasofya 2589 .

[398] 2e. Same as preceding, 331 \{19\}. Bound in a miscellaneous volume containing K. Uqlidus, alMutawassițāt al-handasiyya, and K. Tahrīr al-Majisțī. MANUSCRIPT: This codex (2e) might be TSMK A. 3453 (Karatay: A 7005).

[399] 2.1a. [al-Nīsābūrī] Tawdīh (or Sharh) al-tadhkira (Elucidation of the Memoir), Arabic, 1311, autograph, $329\{9-10\}$. See $\rightarrow$ al-Nīsābūri, 1, Part II.

[40o] 2.1b. Same as preceding, $327\{2-3\}$. Bound with al-Ṭūsìs K. al-tadhkira fì 'ilm al-hay'a.

[401] 2.1c. Same as preceding, 327 \{19\}. Bound with al-Ṭūsì's K. al-tadhkira fì 'ilm al-hay'a. MANUSCRIPT: One of the codices (2.1b or 2.1c) should be the copy now housed as SK Ayasofya 2589 .

[402] 2.1d. Same as preceding [catalogued in the inventory as Tawdīh al-tadhkira], $327\{11\}$.

[403] 2.1e. Same as preceding [catalogued in the inventory as Sharh al-tadhkira], $328\{5\}$. MANUSCRIPT: This codex (2.1e) should be the copy now housed as SK Ayasofya 2646.

[404] 2.If. Same as preceding [catalogued in the inventory as Sharh al-tadhkira al-musammā bitawdịh al-tadhkira], $330\{3-4\}$.

[405] 2.19. Same as preceding, $330\{4-5\}$. MANUSCRIPT: One of the two codices (2.1f, 2.1g) should be the copy now housed as SK Ayasofya 2647.

[406] 2.2a. [al-Shīrāzī.] K. fa' alta fa-lā talum (You Have Done It, So Do Not Condemn), Arabic, 326 \{18-19\}. See $\rightarrow$ al-Shīrāzī 4, in Part II. MANUSCRIPT: TSMK A. 3338 (Karatay: A 7094).

[407] 2.2b. Same as preceding, $327\{1-2\}$. MANUSCRIPT: The second book (2.2b) should be the copy now housed as SK Ayasofya 2668.

[408] 2.3a. [al-'Ubaydī.] Bayān al-Tadhkira (Explanation of the Tadhkira), Arabic, $326\{7\}$. See $\rightarrow$ al'Ubaydī. MANUSCRIPT: TSMK A. 3315 (Karatay: A 7084).

[409] 2.3b. Same as preceding, $327\{4-5\}$. Bound with Sharh al-Chaghminī. MANUSCRIPT: TSMK A. 3325 (Karatay: A 7058).

[410] 2.4. "Sharh al-Tadhkira fì 'ilm al-hay'a," 325 \{17\}. Bound with K. fi 'ilm al-hisāab.

[411] 2.5. Same as preceding, $326\{9\}$.

[412] 2.6. Same as preceding, $327\{5\}$.

[413] 2.7. Same as preceding, $330\{7\}$. MANUSCRIPT: One of the three copies $(2.5,2.6,2.7)$ should be the one now housed as SK Ayasofya 2645 .

[414] 2.8. "Sharh al-Tadhkirafi al-hay'a," $329\{10\}$.

[415] 2.9. Same as preceding, $326\{14\}$.

[416] 2.10. Same as preceding, the autograph copy of its commentator, $331\{13\}$.

[417] 3a. Tahrïr al-Majisțī (Recension of Ptolemy's Almagest), Arabic, 1247, $326\{1\}$.

[418] 3b. Same as preceding, $328\{17-18\}$.

[419] 3c. Same as preceding, $329\{7\}$.

[420] 3d. Same as preceding, $329\{7\}$.

[421] 3e. Same as preceding, $330\{9-10\}$.

[422] 3f. Same as preceding, $330\left\{13^{-14}\right\}$. MANUSCRIPT: One of the two codices (3e, 3 f) should be the copy now housed as TSMK A. 3328 (Karatay: A 7095), personal copy of Bayezid II. 
[423] 3g. Same as preceding [catalogued in the inventory as Taḥrīr Majisțîfi 'ilm al-hay'a], $33^{1}\{1\}$. MANUSCRIPT: This codex (3g) should be the copy now housed as SK Ayasofya 2583.

[424] 3h. Same as preceding, $331\{18-19\}$. Bound in a miscellaneous volume containing $K$. Uqlïdus, al- Mutawassițatt al-handasiyya, and al-Tadhkira fì al-hay'a. MANUSCRIPT: This codex ( $3 \mathrm{~h})$ might be TSMK A. 3453 (Karatay: A 7005).

[425] 3.1. [al-Nīsābūrī.] Tafsìr [or Sharh] al-Tahrīir al-Majisțīi, Arabic, 1305, $329\{14-15\}$. See $\rightarrow$ alNīsābūrī, 2, Part II.

[426] 3.2. "Sharh Tahrīir al-Majisțti," $326\{6-7\}$.

[427] 3.3. Same as preceding, $328\{18\}$.

[428] 4. Zubdat al-idräkfi hay'at al-aflāk (The Essential Understanding of the Configuration of the Orbs), Arabic, $324\left\{15^{-16}\right\}$. Bound with Ibn Sīnā’s K. fi al-manțiq wa-al-hikma al-falsafiyya, an anonymous treatise on astrology, and several other texts. MANUSCRIPT: This codex should be the copy now housed as TSMK A. 3430 (Karatay: A 8749). EDITION: Zubdat al-idräkfi hay'at al-aflāk: ma'a dirāsat al-manhaj al-Ṭūsī al- ílmí fì majāl al-falak, ed. 'Abbās Muhammad Ḥasan Sulaymān (Alexandria: Dār al-Ma 'rifat al-Jāmi'yah, 1994).

[429] 5a. Zubdah-i hay'a (The Essence of Hay’a), Persian, 318 \{10\}. Bound with al-Ṭūsìs Sīfașl.

[430] 5b. Same as preceding, $3_{2}^{26}\{17\}$. Bound with al-Ṭusìs R. Mu ìniyya and Sharḥ-i Mu inizya. MANUSCRIPT: This codex ( 5 b) should be the copy now housed as SK Ayasofya 2670.

[431] 5c. Same as preceding, $3^{29}\left\{15^{-16}\right\}$.

[432] 5d. Same as preceding, 332 \{13\}. Bound with al-Iṣfahānī’s Talkhīs al-makhrūṭāt, al-Ṭūsì's Jawāmi' al-hisāab, K. mi'yār al-ash'ār, and other treatises. MANUSCRIPT: This codex (5d) should be the copy now housed as TSMK A. 3455 (Karatay: A 8752).

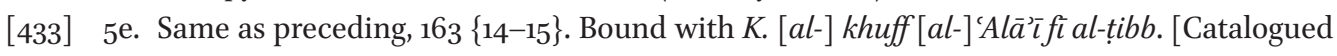
under al-Kutub al-tibbiyya.]

[434] 5(i). K. tarjamat al-zubda fi 'ilm al-hay'a (Arabic translation of Zubdah-i hay'a), Arabic, 290 \{10-11\}. Bound with K. tashïlal-fawā'id, R. fì bayān țuruq al-hadìth, R. al-'alā'iyya fì ilm al-hisāb, and $R$. fial-hadīth. [Catalogued under kutub ilm al-șarfwa-al-nahw.]

AL-'UBAYDĪ, Jalāl al-Dīn Faḍl Allāh (d. 1350)

[435] 1a. Bayānal-Tadhkira wa-tibyān al-tabșira (Explanation of the Tadhkira and Exposition of the Enlightenment), Arabic, 1328, 326 \{7\}. See $\rightarrow$ al-Ṭūsī, 2.3, Part II. MANUSCRIPT: TSMK A. 3315 (Karatay: A 7084).

[436] 1b. Same as preceding, 327 \{5\}. Bound with al-'Ubaydī's Sharh al-mulakhkhaṣ. MANUSCRIPT: TSMK A. 3325 (Karatay: A 7058).

[437] 2a. Sharh al-mulakhkhaṣ, Arabic, $327\left\{3^{-4}\right\}$. Bound with al-'Ubaydì's Bayān al-Tadhkira. See $\rightarrow$ al-Chaghmīnī, 1.4. MANUSCRIPT: TSMK A. 3325 (Karatay: A 7058).

[438] 2b. Same as preceding, $316\{13\}$. Bound with K. al-hidāya fí al-hikma and al-Ṭūsìss Sĩ faṣl. MANUSCRIPT: SK Ayasofya 2474.

\section{ANONYMOUS/UNIDENTIFIED AUTHORS}

[439] 1. Sharḥ k. Majisțī Bațlamyūs (A Commentary on Ptolemy's Almagest), 329 \{11\}. Bound with Ibn al-Haytham's commentary on Almagest and al-'Urḍī's Kayfiyyat al-arșād. MANUSCRIPT: TSMK A. 3329 (Karatay: A 7140).

[440] 2. K. burhān [al-]hay'a (Book on the Demonstrations of the Configurations), $319\{8\}$. Bound with two anonymous treatises on [the science of] the stars. 
[441] 3a. R. fi al-hay'a (Treatise on the Configurations [of the Heavens]), $323\{9-10\}$. Bound with R. fi al-daraj wa-al-daqā’iq fì al-nujūm (Treatise on Degrees and Minutes) and R. fi al-hisāb (Treatise on Arithmetic).

[442] 3b. Same as preceding, language specified as Arabic, $332\{9\}$.

[443] 3c. Same as preceding, 121 \{18-19\}. Bound with K. al-șihăh fí al-furs and K. qurrat al-'ayn min qibal al-lațāif wa-al-tașawwuf. [Catalogued under Kutub al-tașawwuf, etc.]

[444] 3d. "K. fi al-hay'a" (Book on the Configurations [of the Heavens]), 328 \{1\}. Bound with Qādīizāde al-Rūmì's Sharh al-Chaghmin̄ī.

[445] 4. K. al-dawā'ir fí 'ilm al-hay'a (Book on Circles in the Science of the Configuration [of the Heavens]), $328\{5\}$.

[446] 5. Mukhtașarfíal-hay'a (Abridgment of the Configurations [of the Heavens]), 332 \{1\}. Bound with al-Ṭusì's R. mu'iniyya.

[447] 6. R. fi zill al-miqyās min qibal al-hay'a wa-al-nujüm (Treatise on the Shadow [of the Instrument] of the Measurement), $123\{6-7\}$. Bound with K. al-qalä'id wa-al-farā'id min qibal alnașä̉ih wa-al-tașawwuf. [Catalogued under Kutub al-tașawwuf, etc.]

[448] 7. R. min qibal al-hay'a, 335 \{7\}. Bound with R. Najm al-milla wa-al-dìn fì al-hisāb al-hawā̄ì.

\section{PART THREE \\ Arithmetic ('ilm al-ḥisāb)}

AL-BAGHDĀDĪ, Abū Bakr 'Abd Allah al-Ḥusayn al-Shaqqāq (d. 1117)

[449] 1. Sharh al-kāfífí ilm al-hisāb (Commentary on al-Karajì's Sufficient on the Science of Arithmetic), Arabic, $333\left\{15^{-16}\right\}$. Bound with al-Karajī's K. al-kāfi. MANUSCRIPT: TSMK A. 3135 (Karatay: A 7033). See $\rightarrow$ al-Karajī.

AL-FĀRISĪ, Kamāl al-Dīn al-Ḥasan b. ‘Alī b. al-Ḥasan (d. 1319)

[450] 1a. K. asās al-qawā'id fi ușül al-fawā’id (The Basis of the Rules Regarding the Principles of the Fawāìd), Arabic, 333 \{8\}. See $\rightarrow$ Ibn al-Khawwām, 1. EDITION: Asās al-Qawā'id fì ușūlal-fawāìd, ed. Muștafā Mawālidī (Cairo: Machad al-Makhțūtāt al-'Arabīyah, 1994).

[451] 1b. Same as preceding, $333\{10-11\}$.

[452] 1c. Same as preceding, $333\left\{13^{-14}\right\}$.

[453] 1d. Same as preceding, $333\{17\}$. MANUSCRIPT: Three of the four codices should be the copies now housed as TSMK A. 3132 (Karatay: A 6996), A. 3140 (Karatay: A 6997), A. 3155 (Karatay: A 6998).

AL-GHARBĪ, Jalāl al-Dīn 'Alī (fl. ca. 1350)

[454] 1. K. al-mu jizāt al-najībiyya fì sharh al-R. al-'alāìyya (Najībiyya Miracles in Commenting on [al-Turkistānì's] 'Alä’iyya Treatise on Arithmetic), 334 \{11-12\}. MANUSCRIPT: TSMK A. 3117 (Karatay: A 7012). See $\rightarrow$ al-Turkistānī.

AL-GHAZNAWĪ, Muhammad b. 'Abd al-Karīm (fl. thirteenth century)

[455] 1. Tuhfat al-șudūr fi al-hisāb (Gift from the Hearts), Persian, $228\{1\}$. Bound with Rawdat alfașāha fì șanā’i al-badīíyya al-shi'riyya and Qurrat al-'uyūn fì al-nawādir. [Catalogued under al-dawāwin al-'arabiyya, etc.] 
AL-KASHGĀRĪ, 'Abd Allah b. As'ad b. 'Umar (fl. fourteenth century)

[456] 1. R. al-imādiyya fi al-țuruq al-hisābiyya (The Imādiyya Treatise on Arithmetic Methods), Arabic, $334\{17-18\}$. MANUSCRIPT: This codex should be the copy now housed as SK Ayasofya 2739 .

AL-KĀSHĪ, Ghiyāth (al-Milla wa-) al-Dīn Jamshīd b. Mas'ūd b. Maḥmūd (d. 1429)

See also al-Kāshī in Part One ('ilm al-nujūm).

[457] 1a. Miftāh al-hisāb (The Key to Arithmetic), Arabic, 1427, $334\{10\}$.

[458] 1b. Same as preceding, 335 \{3\}. MANUSCRIPT: One of the codices should be TSMK A. 3479 (Karatay: A 7019). EDITION: Miftāḥ al-ḥisāb, ed. Nādir al-Nābulsī (Damascus: Wizārat al-Ta līm al-`̄̄lī, 1977).

AL-KĀSHĪ, 'Imād al-Dīn Yahyyā b. Aḥmad (fl. ca. 1343)

[459] 1a. K. al-îdāh fì sharh al-Fawā'id al-bahä’iyya (Elucidation of Goals in Commenting on the Fawāidd), $333\{12\}$. See $\rightarrow$ Ibn al-Khawwām, 1.2. MANUSCRIPT: SK Ayasofya 2716.

[460] 1b. Same as preceding [catalogued in the inventory as K. ị̀āḥ al-maqāṣid fì sharh al-Fawā̉id], $334\{14-15\}$. Bound with Sharh manțiq al-mațālic. MANUSCRIPT: TSMK A. 3142 (Karatay: A 6999).

[461] 2. K. al-lubāb fì al-hisāb (Quintessence on Arithmetic), Arabic, 334 \{8\}. MANUSCRIPT: This codex should be the copy now housed as SK Ayasofya 2757.

AL-KARAJ̄̄, Abū Bakr Muhammad b. al-Ḥusayn (fl. ca. 100o)

[462] 1. K. al-käfífí ilm al-hisāb (The Sufficient on the Science of Arithmetic), Arabic, 333 \{15\}. Bound with al-Baghdādì's commentary on it. MANUSCRIPT: TSMK A. 3135 (Karatay: A 7033). EDITION: al-Kāfífí al-hisāb, ed. Samī Shalhūb (Aleppo: Jāmi'at Ḥalab, Ma'had al-Turāth al-'ilmī al-'Arabī, 1986).

[463] 1.1. [al-Baghdādī.] "Sharh al-kāfi fí 'ilm al-hisāab," 333 \{15-16\}. Bound with al-Karajī's K. al-kāfí. MANUSCRIPT: TSMK A. 3135 (Karatay: A 7033). See $\rightarrow$ al-Baghdādī.

IBN AL-KHAWWĀM, 'Imād al-Dīn Abū 'Alī 'Abdallāh b. Muḥammad al-Baghdādī (d. 1328)

[464] 1. R. al-fawā’id al-bahā’iyya fì al-qawā’id al-hisābiyya (The Bahāì Scholia on Rules of Arithmetic), Arabic, 1259, 334 \{18\}. MANUSCRIPT: SK Ayasofya 2729. EDITION: İhsan Fazlığlu, “İbn el-Havvam (öl. 724/1324) ve Eseri el-Fevaid el-Bahaiyye fi el-Kavaid el-Hisabiyye Tenkitli Metin ve Tarihi Değerlendirme" (master's thesis, Istanbul University, 1993).

[465] 1.1a. [al-Fārisī.] K. asās al-qawā'id fì ușül al-fawā’id (The Base of the Rules in the Principles of Uses in Arithmetic), Arabic, $333\{8\}$. See $\rightarrow$ al-Fārisi.

[466] 1.1b. Same as preceding, $333\{10-11\}$.

[467] 1.1c. Same as preceding, $333\{13-14\}$.

[468] 1.1d. Same as preceding, $333\{17\}$.

[469] 1.2a. [al-Kāshī, Yaḥyā b. Aḥmad.] K. al-ịdāh fì sharh al-fawā’id al-bahā’iyya (Elucidation of Goals in Commenting on the Fawāidd), 333 \{12\}. See $\rightarrow$ al-Kāshī, Yahya. MANUSCRIPT: SK Ayasofya 2716.

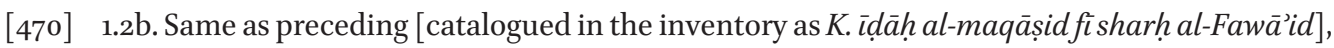
$334\{14-15\}$. Bound with Sharh manțiq al-mațālī́ . MANUSCRIPT: TSMK A. 3142 (Karatay: A 6999).

[471] 1.3. "Sharh [al-] bahā’iyya fi al-hisāb," $335\{3\}$. 
KHAYR AL-DĪN KHALĪL B. IBRĀHĪM (d. late fifteenth century)

[472] 1. Mushkil-gushāy-i ḥussāb fi 'ilm al-ḥisāb (Problem Solver for Arithmeticians), Persian, $334\{12\}$.

AL-KIRMĀNĪ, Abū Isḥāq (fl. late fifteenth century)

[473] 1. Sharh al-shamsiyya (Commentary on al-Nīsābūrī's treatise on Arithmetic), Arabic, $333\{16\}$. See $\rightarrow$ al-Nīsābūrī, 1.1, Part III. MANUSCRIPT: TSMK A. 3153 (Karatay: A 7017).

AL-NĪSĀBŪRĪ, al-Ḥasan b. Muḥammad b. al-Ḥusayn Nizāam al-Dīn al-A'raj (d. ca. 1329-30)

See also al-Nīsābūrī in Part One ('ilm al-nujūm) and Part Two ('ilm al-hay'a).

[474] 1a. R. al-shamsiyya fì 'ilm al-hisāb (The Shamsiyya Treatise), Arabic, $328\{15\}$. Bound with Qādīzāde al-Rūmī's Sharh al-Chaghmīn̄ and an anonymous Persian treatise. MANUSCRIPT: This codex (1a) should be the copy now housed as SK Ayasofya 2659. EDITION: Elif Baga, "Nizamuddin Nisaburi ve Şemsiyye Fi'l-Hisab Adlı Matematik Risalesinin Tahkik, Tercüme ve Tarihi Bir Değerlendirmesi" (master's thesis, Sakarya University, 2007).

[475] ib. Same as preceding, $334\{5\}$. Bound with al-Zanjānī's R. käfiya fí al-ḥisāb. MANUSCRIPT: This should be TSMK A. $315^{2}$ [Karatay: A. 7016].

[476] 1c. Same as preceding, $334\{8\}$.

[477] 1d. Same as preceding, $335\{9\}$. MANUSCRIPT: The two codices (1c, 1d) should be two of the three copies now housed as SK Ayasofya 2725, TSMK A. 3149 (Karatay: A 7014), and A. 3150 (Karatay: A 7015).

[478] 1e. Same as preceding [catalogued in the inventory as R. al-nizämiyya fi al-hisāb], $334\{14\}$.

[479] 1(i). [al-Shīrāzī, Maḥmūd b. Muḥammad b. Mahmūd (not the better known al-Shīrāzī).] Tarjamat al-R. al-Shamsiyya (Translation of the Shamsiyya Treatise), Persian, $334\{13\}$. MANUSCRIPT: TSMK A. 3118 (Karatay: F 226).

[480] 1.1. [al-Kirmānī.] Sharh al-shamsiyya (Commentary on the Shamsiyya Treatise), Arabic, $333\{16\}$. See $\rightarrow$ al-Kirmānī. MANUSCRIPT: TSMK A. 3153 (Karatay: A 7017).

[481] 1.2. Sharh al-shamsiyya, language specified as Persian, $334\{1-2\}$.

QĀḌI AL-HUMĀMĪYA, Jamāl al-Dīn Ahmad al-'Abbās Ahmad b. Thābit (d. 1272)

[482] 1. Ghunyat al-hussāb fí 'ilm al-hisāb (The Wealth of the Arithmeticians), Arabic, $333\left\{9^{-10}\right\}$. Bound with R. fi i ilm al-hisāb. MANUSCRIPT: SK Ayasofya 2728.

AL-QŪSHJ̄̄, Abū al-Qāsim 'Alā' al-Dīn 'Alī b. Muḥammad (d. 1474)

See also al-Qūshjī in Part One ('ilm al-nujūm) and Part Two ('ilm al-hay'a).

[483] 1a. R. al-Muhammadiyya fi al-hisāb (The Muhammadiyya Treatise on Arithmetic), Arabic, 1473, $332\{11-12\}$. Bound with R. al-fathiyya fi 'ilm al-hay'a. MANUSCRIPT: SK Ayasofya 2733 .

[484] 1b. Same as preceding, 151 \{19\}. Bound with al-Nīsābūr’’’ R. fíal-țibb al-nabawī, al-Fanārì̄s Sharh İsāghüjī, 'Alī al-Qūshjì's R. fathiyya. [Catalogued under al-Kutub al-țibbiyya.]

ȘALĀH AL-DīN MŪSĀ (fl. late fourteenth century?)

[485] 1. al-R. al-ṣalāhiyya fì al-qawā’id al-hisābiyya (Șalāḥ's treatise on the rules of Arithmetic) [catalogued in the inventory as Mukhtașar al-Șalāhfíal-hisāab], $334\{19\}$. Bound with its anonymous commentary. MANUSCRIPT: TSMK A. 3133 (Karatay: A 7010).34

[486] 1.1a. "Sharh mukhtașar al-Ṣalāh fì al-hisāab," $334\{19\}-335$ \{1\}. Bound with al-R. al-ṣalāhiyya. MANUSCRIPT: TSMK A. 3133 (Karatay: A 7010). 
[487] 1.1b. "Sharḥ al-mukhtașar al-Șaläh̆fíal-ḥisāb," $334\{6\}$.

[488] 1.1c. "K. sharh al-Ṣalāh fi i ilm al-ḥisāb," 333 \{11\}. MANUSCRIPT: These two codices (1.1b, 1.1c) should be the copy now housed as SK Ayasofya 2751 and TSMK A. 3141 (Karatay: A 7011). ${ }^{35}$

AL-SAMAW’AL, Abū Nașr b. Yaḥyā b. 'Abbās al-Maghribī (d. 1174-75)

[489] 1. K. al-bāhirfí ilm al-hisāb (The Brilliant in the Science of Arithmetic), Arabic, 333 \{13\}. MANUSCRIPT: SK Ayasofya 2718. EDITION: al-Bāhir en Algèbre d'as-Samaw'al, ed., notes, and introduction by S. Ahmad and Roshdi Rashed (Damascus: Presses de l'Université de Damas, 1973).

AL-SAJĀWANDĪ, Sirāj al-Dīn Abū Ṭāhir Muḥammad (d. ca. 1203)

[490] 1. R. fi'l-hisāb, Arabic, $335\{1-2\} .{ }^{36}$ MANUSCRIPT: This might be the copy now housed as SK Ayasofya 4855 .

AL-ṬABARĪ, Abū Jacfar Muhammad b. Ayyūb b. Hāsib (fl. eleventh century)

[491] 1. Miftāh al-mu'āmalātf fí ilm al-hisāa (The Key to Transactions in the Science of Arithmetic), Persian, $335\{2\}$. MANUSCRIPT: This codex should be the copy now housed as SK Ayasofya 2763 .

AL-TURKISTĀNĪ, Jamāl al-Dīn Sa'īd b. Muhammad (fl. ca. 1300)

[492] 1a. al-R. al-'alā'iyya fì al-masā'il al-hisābiyya (The 'Alā'iyya Treatise on Arithmetic Problems), Arabic, $334\{3\}$. Bound with R. Ajwibat Ibn Sìnā li-masāil Abì al-Rayhān [al-Bïrūnī]. MANUSCRIPT: This codex (1a) should be the copy now housed as SK Ayasofya 2737.

[493] 1b. Same as preceding, $334\{4\}$.

[494] 1c. Same as preceding, $324\{8\}$. Bound with al-Mizzī's al-Rawḍat al-muzaharrāt fí al-'amal bial-muqanțarāt and R. kashfal-rayb fi al-amal bi-al-jayb. MANUSCRIPT: This codex (1c) might be the copy now housed as TSMK A. 3119 (Karatay: A 7037).

[495] 1d. Same as preceding, $290\{10\}$. Bound with K. tashïl al-fawā’id fi al-naḥw, R. fì bayān țuruq al-hadìth, K. tarjamat al-zubda fi 'ilm al-hay'a, and R. fi al-hadith. [Catalogued under kutub 'ilm al-șarfwa-al-nahw.]

[496] 1.1. [Jalāl al-Dīn 'Alī al-Gharbī.] K. al-mu'jizāt al-naj̄̄biyya fì sharh al-R. al-'alä’iyya (Najībiyya Miracles in Commenting on the 'Alä'iyya Treatise on Arithmetic), 334 \{11-12\}. MANUSCRIPT: TSMK A. 3117 (Karatay: A 7012). See $\rightarrow$ al-Gharbī.

AL-Ṭ̂̄SĪ, Nașīr al-Dīn Abū Ja'far Muhammad b. Muhammad (d. 1274)

See also al-Ṭūsī in Part One ('ilm al-nujūm), Part 2 ('ilm al-hay'a), and Part Four ('ilm al-handasa).

[497] 1a. Jawāmi al-hisāb bi-al-takht wa-al-turāb (Comprehensive Arithmetic on Using the Dust Board) [catalogued in the inventory as Risāla al-ḥisāb], $33^{2}\{13\}$. Bound with al-Iṣfahānī's Talkhịs al-makhrūtāat, K. mi'yār al-ash'ārr, and al-Ṭūsìs Zubdat al-idrāk. MANUSCRIPT: TSMK A. 3455 (Karatay: A8752), EDITION: Ahmad S. Saidan, "Al-Ṭūsī,Jawāmī'al-Hisāab," Al-Abhāth 20 (1967): 91-163.

[498] 1b. Same as preceding [catalogued in the inventory as K. jawāmi ' al-hisāb fic 'ilm al-hisāb], 160 $\{9\}$. Bound with $K . f_{i}$ 'ilm al-tashrịh min qibal al-țibb. [Catalogued under al-Kutub al-țibbiyya.]

[499] 2. R. al-jabr wa-al-muqābala fì al-hisāb (Treatise of Algebra), $335\{6\}$. 
AL-WĀLISHTĀNĪ, Mạ̣mūd b. Muḥammad b. Qawām al-Hirawī (fl. ca. 1445)

[500] 1. Mukhtașar dar 'ilm-i hisāb (Compendium in the Science of Arithmetic) [catalogued in the inventory as R. färisiyya fì 'ilm al-hisāb (A Persian Treatise on the Science of Arithmetic)], Persian, $333\{18\}$. Bound with al-Shirwānī’s translation of Șafì al-Dīn al-Urmawī's work on music. MANUSCRIPT: This codex should be the copy now housed as SK Ayasofya 2735.

AL-ZANJĀNĪ, 'Izz al-Dīn 'Abd al-Wahhāb Ibrāhīm (fl. ca. 1262)

[501] 1a. R. al-käfiya fi al-hisāab (The Sufficient Treatise on Aritmetic), 316 \{11-12\}. Bound with alṬūsī’s Sīfașl. MANUSCRIPT: SK Ayasofya 2732.

[502] 1b. Same as preceding, $334\left\{5^{-6}\right\}$. Bound with al-Nīsābūrìs al-R. al-Shamsiyya. MANUSCRIPT: TSMK A. 3152 [Karatay: A. 7016]).

[503] 2a. 'Umdat al-hisāb (Pillar of Arithmetic), Arabic, 335 \{8\}. MANUSCRIPT: TSMK A. 3145 (Karatay: A 7009$).^{37}$

[504] 2b. Same as preceding, 335 \{4\}. Bound with Madkhal Babūsfíal-hiyal and al-Zanjānī’s K. qusțās al-mu'ādala fì 'ilm al-jabr wa-al-muqābala. MANUSCRIPT: TSMK A. 3457 (Karatay: A 7008). EDITION: Maryam Zamani, Two Treatises of Izz al-Dīn Zanjānī, Facsimile Edition of Manuscript no. 3457, Library of Sultan Ahmad III, Topkapi (Istanbul) (Tehran: Mirāth-i Maktūb, 2016).

[505] 3. K. qusțās al-mu'ädala fí 'ilmal-jabr wa-al-muqābala (The Scale of Equality on the Science of Algebra), Arabic, 335 \{4-5\}. Bound with Madkhal Babūs fí al-hiyal and al-Zanjānī’s 'Umdat alhussāb/hisāb. MANUSCRIPT: TSMK A. 3457 (Karatay: A 7008).

\section{ANONYMOUS/UNIDENTIFIED}

[506] 1a. K. al-mi'a wa-al-ishrin fi hisäb al-darb (The Book of the One Hundred and Twenty in Arithmetic Multiplication), $318\left\{15^{-16}\right\}$.

[507] 1b. Same as preceding, $323\{14\}$. Bound with $R$. 'alä țarìq al-su'äl wa-al-jawāb fi al-nujūm and other treatises.

[508] 2a. R. fi al-hisāb (Treatise on Arithmetic), $99\{15\}$. Bound with K. fi i ilm al-farä’id. [Catalogued under Kutub al-figh wa-kutub manāqib al-a'imma.]

[509] 2b. Same as preceding, $322\{11\}$. Bound with K. al-shajara wa-al-thamara fi ahkām al-nujūm.

[510] 2c. Same as preceding, $334\{7\}$.

[511] 2d. Same as preceding, language specified as Persian, $335\{9\}$.

[512] 2e. "K. fi al-hisāb," $323\{10-11\}$. Bound with $R$. fi al-hay'a and R. fi al-daraj wa-al-daqā'iq fì alnujūm.

[513] 2f. "R. fi 'ilm al-hisāb," 98 \{19\}-99 \{1\}. Bound in a volume containing R. ilm al-wafq and K. almasāil al-dawriyya al-wāqi'a fìal-ahkām al-shar'iyya fíal-figh. [Catalogued under Kutubal-figh wa-kutub manāqib al-a’imma.]

[514] 2g. Same as preceding, $327\{16\}$. Bound with al-Ṭūsī's K. Uqlīdus and al-Ahwāzīs Sharh al-M. al-āshira min K. Uqlìdus.

[515] 2h. Same as preceding, $333\{19\}$.

[516] 2i. Same as preceding, language specified as Persian, $327\{12\}$. Bound with 'Alī al-Qūshjī's $R$. dar 'ilm-i hay'a and Qādịāie al-Rūmī's Sharh ashkāl al-ta’siss. MANUSCRIPT: This codex should be SK Ayasofya 2640.

[517] 2j. Same as preceding, language specified as Persian, $333\{9\}$. Bound with Qāọī al-Humāmīya's K. ghunyat al-hussāb. MANUSCRIPT: This codex (2j) should be the copy now housed as SK Ayasofya $2728 .^{38}$

[518] 2k. "K.fí 'ilmal-hisāb," $325\{16\}$. Bound with Sharh al-Tadhkira. 
[519] 2l. Same as preceding, $334\{1\}$.

[520] 2m. "K. fi al-hisāb," language specified as Arabic, $334\{4\}$. MANUSCRIPT: This codex (2m) should be the copy now housed as SK Ayasofya 2723 .

[521] 2.1a. "Sharh R.fí 'ilm al-hisāb," $333\{14-15\}$. MANUSCRIPT: This codex (2.1a) should be the copy now housed as TSMK A. 3154 [Karatay: A 7013]. ${ }^{39}$

[522] 2.1b. Same as preceding, $285\{13\}$. Bound with R. kāshifat al-mushkilät al-'alä’iyya and Hāshiyat k. al-wäfiya al-ma'rūf bi-al-mutawassit fi al-naḥw. [Catalogued under kutub 'ilm al-șarfwa-alnahw.]

[523] 2.1c. "Sharh mukhtașar fi al-hisāab," 334 \{10-11\}.

[524] 3a. R. al-'adad bi-awḍ̂ā'al-așābic (Treatise on Counting by Finger Reckoning), 322 \{16-17\}. Bound with K. al-'amal bi-al-kura and R. Fattāhī fíal-inshä'.

[525] 3b. R. al-hisāb bi-'aqd al-așābic (Treatise on Counting by Fingers), $118\{18-19\}$. Bound with al-Qāshānī's R. nūriyya, K. al-ișțilāhāt, R. zamāniyya, R. fì tahqüq al-kalām, R. fìmas'ala kulliyya fì al-haqā’iq, R. fì jawāb al-masā'il al-madhkūra, R. fì sharh su'àl Kumayl b. Ziyād 'an Amīr al-Mu'minin 'Alì min qibal al-tașawwuf. [Catalogued under Kutub al-tașawwuf wa-kutub alnașā'ih, etc.]

[526] 4. K. al-kifäya fi ilm al-hisāb (The Book of Sufficiency in Arithmetic), $328\{19\}-329\{1\}$. Bound with al-Nasawī's K. al-tajrïd fi-ușül al-handasa (Abstract of Euclid's Elements) and K. Uqlïdus. MANUSCRIPT: This codex should be SK Fatih 3441.

[527] 5. Sharh al-shamsiyya (Commentary of the Shamsiyya Treatise), language specified as Persian, $334\{1-2\}$.

[528] 6. Iqnā' fì al-misāha min qibal al-hisāa (Persuasive Argument concerning Surveying), Arabic, fifteenth century, 334 \{7\}. MANUSCRIPT: SK Ayasofya 2715. EDITION: İhsan Fazlığlu, Uygulamalı Geometrinin Tarihine Giriş: El-İkna fi ilmi'l-misaha (Istanbul: Dergah, 2004).

[529] 7. K. jāmi' ușül al-hissāb (Compendium of Principles of Arithmetic), 334 \{16\}. Bound with K. 'umdat al-kuttäb. ${ }^{40}$

[530] 8. R. fi al-siyāqa min qibal ilm al-hisāb (Persian Treatise on Accounting Arithmetic), Persian $334\{9\} .41$

[531] 9. R. fi ma'rifat al-hisāab al-hindi (Treatise on Understanding Indian Arithmetic), $335\left\{5^{-6}\right\}$.

[532] 10. R. Najm al-milla wa-al-dīn fi al-hisāb al-hawā̄ì (Treatise by Najm al-Dīn on Mental Arithmetic), $335\{7-8\}$. Bound with an anonymous $R$. min qibal al-hay'a.

[533] 11. Mukhtașar fi qawā'id al-hisāb (Abridgment of the Rules of Arithmetic), $226\{6-7\}$. Bound with Sharaf al-Rāmì's Anīs al-'ushshāq. [Catalogued under Kutub al-siyar wa-al-tawārīkh, etc.]

[534] 12. R. al-tațāmfì ilmal-hisāb, $35^{8}$ \{3\}. Bound with Ibn Mubārak Shāh's Sharh Hikmat al-hidāya and other treatises. [Catalogued under kutub al-hikmat al-islämiyya, etc.]

\section{PART FOUR}

Geometry ('ilmal-handasa)

AL-AHWĀZĪ, Abū'l-Ḥasan (fl. ca. 100o)

[535] 1. Sharh al-M. al-'äshira min k. Uqlïdus (Commentary of Book X of Euclid's Work), Arabic, 327 $\left\{15^{-16}\right\}$. Bound with al-Ṭūsìs K. Uqlïdus and R. fì 'ilm al-hisāäb. MANUSCRIPT: This codex should be the copy now housed as SK Ayasofya 2742. 
APOLLONIUS OF PERGA (fl. second half of third century BCE)

[536] 1a. K. Ablūniyūs fì al-makhrūtāt (Book of Apollonius On Conics), 330 \{8\}. EDITION: Apollonius de Perge, Coniques: Texte grec et arabe, ed. Roshdi Rashed (New York: Walter de Gruyter, 2008).

[537] 1b. Same as preceding, $330\{8-9\}$. MANUSCRIPT: One of the two codices (1a, $1 \mathrm{~b})$ should be the copy now housed as SK Ayasofya 2762.

[538] 1c. Same as preceding, $33^{1}\{10-11\}$. Bound as the first book of a volume containing books of astronomy and geometry.

[539] 1.1. [Ibn al-Haytham.] K. Ablūniyūs fì al-makhrūtāatt (Book of Apollonius On Conics), Arabic, 332 $\left\{\begin{array}{lll}10 & 11\end{array}\right\}$. Bound with several other unnamed treatises of Ibn al-Haytham. See $\rightarrow$ Ibn al-Haytham, 1, Part IV.

[540] 1.2a. [al-Ișfahānī.] Talkhīs al-makhrūṭāt (Abridgment of the Conics), Arabic, $327\{7\}$. See $\rightarrow$ al-Ișfahānī.

[541] 1.2b. Same as preceding, 331 \{11-12\}. MANUSCRIPT: One of the two copies should be SK Ayasofya 2724 .

[542] 1.2c. Same as preceding, 332 \{12\}. Bound with R. al-hisāb, K. mi'yār al-ash'ār , al-Ṭūsì's Zubdat al-idrāk, and other treatises. MANUSCRIPT: TSMK A. 3455 (Karatay: A 8752).

[543] 1.3. [al-Shirāzī, 'Abd al-Malīk.] Tașaffuḥ al-makhrūṭāt (Examinining the Conics), 331 \{8\}. MANUSCRIPT: TSMK A. 3463 (Karatay: A 6995). See $\rightarrow$ al-Shirāzī, 'Abd al-Malīk.

AL-BŪZJĀNĪ, Abū al-Wafā’ Muḥammad b. Muḥammad b. Yahyyā (d. 997 or 998)

See also al-Būzjānī in Part One ('ilm al-nujūm).

[544] 1. K.fímāyuhtāj ilayhi min a mâal al-handasa (Book on What Is Required of Geometric Operations), Arabic, 326 \{5\}. MANUSCRIPT: SK Ayasofya 2753. EDITION: Mãyuhtāàj ilayhial-șāni ‘ min 'ilm al-Handasah, ed. Ṣāliḥ Aḥmad 'Alī (Baghdad: Jāmi'at Baghdād, Markaz Ihyā’ al-Turāth al-'ilmī al-'Arabīi, 1979).

IBN AL-HAYTHAM, Abū 'Alī al-Ḥasan b. al-Ḥasan (d. ca. 1040)

See also Ibn al-Haytham in Part One ('ilm al-nujūm) and Part Two ('ilm al-hay'a).

[545] 1. K. Ablūniyūsfíal-makhrūtāat (Book of Apollonius On Conics), Arabic, 332 \{10-11\}. Bound with several other unnamed treatises of Ibn al-Haytham. EDITION:J. P. Hogendijk, Ibn al-Haytham's Completion of the Conics (New York: Springer-Verlag, 1985). See $\rightarrow$ Apollonius of Perga, 1.1.

AL-IṢFAHĀNĪ, Abū al-Fatḥ Muhāmmad b. Qāsim b. Faḍl (fl. ca. 1120)

[546] 1a. Talkhiss al-makhrūtăat (Abridgment of the Conics), Arabic, $327\{7\}$. See $\rightarrow$ Apollonius of Perga, 1.2 .

[547] 1b. Same as preceding, 331 \{11-12\}. MANUSCRIPT: SK Ayasofya 2724.

[548] 1c. Same as preceding, 332 \{12\}. Bound with al-Ṭūsì's Jawāmi' al-hisāab and Zubdat al-idrāk, K. mi'yār al-ash'ār, and other treatises.

AL-NASAWĪ, Abū al-Ḥasan 'Alī b. Aḥmad (fl. eleventh century)

[549] 1. K. al-tajrìd fì ușūl al-handasa (Abridgment of the Elements of Geometry), Arabic, $328\{19\}$. Bound with al-Ṭūsì's Tahrīr uṣūl Uqlïdus and K. al-kifāya fì 'ilm al-ḥisāb. MANUSCRIPT: This codex should be the copy now housed as SK Fatih 3441. 
QĀḌ̂̄ZĀDE AL-RŪMĪ (d. after 1440)

See also Qāḍīzāde al-Rūmī in Part Two ('ilm al-hay’a).

[550] 1a. Sharh ashkāl al-ta'sīs (Commentary on al-Samarqandī's Compendium of Geometry), Arabic, $327\{12-14\}$. Bound with 'Alī al-Qūshjī's $R$. dar 'ilm-i hay'a and a Persian treatise on Arithmetic. EDITION: Ashkāl Al-Ta’sīs lìl-Samarqandī \& Sharh Qāậ̄Zādah al-Rūmī, ed. Muḥammad Suwaysī (Tunis: Bayt al-Hikmah, 1984).

[551] 1b. Same as preceding, $329\{14\}$.

[552] 1c. Same as preceding, $330\{18\}$. MANUSCRIPT: The two copies ( $1 \mathrm{~b}, \mathrm{cc})$ should be those now housed as SK Ayasofya 2743 and SK Ayasofya 2744.

[553] 1d. Same as preceding, $33^{2}\{2-3\}$. Bound with al-Samarqandī's Ashkäl al-ta’sīs and al-Abharī's Hikmat al-hidāya.

[554] 1e. Same as preceding, $332\{6-7\}$. Bound with the author's Sharh al-mulakhkhaṣ.

[555] 1.1. [Quțb al-Dīn Çelebī.] Hāashiyat sharh ashkäl al-ta’sīs, Arabic, $327\{17-18\}$. See $\rightarrow$ Quțb al-Dīn Çelebī.

QUṬB AL-DĪN ÇELEBĪ, Muḥammad b. Muḥammad b. Qāḍīzāde al-Rūmī (fl. late fifteenth century)

[556] 1. Häshiyat sharh ashkāl al-ta'siss (Supercommentary on al-Samarqandì's Propositions for the Foundation), Arabic, 327 \{17-18\}. See $\rightarrow$ Qāạīzāde al-Rūmī, 1.1, Part IV.

AL-SAMARQANDĪ, Shams al-Dīn Muḥammad b. Ashraf al-Ḥusaynī (d. ca. 1322)

[557] 1a. Ashkālal-ta’sīs (The Propositions for the Foundation), Arabic, 332 \{2\}. Bound with Qādīizāde al-Rūmī's Sharh Ashkāl al-ta’siss and al-Abharìs Hikmat al-hidāya. EDITION: Gregg De Young, "The Ashkāl al-Ta'sīs of al-Samarqandī: A Translation and Study," Zeitschrift für Geschichte der arabisch-islamischen Wissenschaften 14 (2001): 57-117.

[558] 1b. Same as preceding, $64\{12\}$. Bound with K. al-ma'ärif fi sharḥ al-Șahā'iff fi 'ilm al-kalām. [Catalogued under Kutub iilm ușül al-dìn.]

[559] 1c. Same as preceding, $166\{13\}$. Bound with Mukhtașar sharîf fi șinā'at al-țibb. [Catalogued under al-Kutub al-tibbiyya.]

[56o] 1.1a. [Qāḍīzāde al-Rūmī.] Sharh ashkāl al-ta’siss, Arabic, 327 \{12-14\}. Bound with 'Alī al-Qūshjī's R. dar 'ilm-i hay'a and a Persian treatise on arithmetic. See $\rightarrow$ Qāọīzāde al-Rūmī, 1.1, Part IV.

[561] 1.1b. Same as preceding, $329\{14\}$.

[562] 1.1c. Same as preceding, $330\{18\}$. MANUSCRIPT: The two codices (1.1b, 1.1c) should be the copies housed as SK Ayasofya 2743 and SK Ayasofya 2744.

[563] 1.1d. Same as preceding, $332\{2-3\}$. Bound with Samarqandī's Ashkāl al-ta'sīs and al-Abharì's Hikmat al-hidāya.

[564] 1.1e. Same as preceding, $332\{6-7\}$. Bound with Qāẹizāde al-Rūmì's Sharh al-mulakhkhaṣ.

[565] 1.1.1. [Quṭb al-Dīn Çelebī.] Hāshiya sharh ashkāl al-ta’siss, Arabic, $327\{17-18\}$. See $\rightarrow$ Quṭb al-Dīn Çelebī.

AL-SARĪ, Najm al-Dīn Abū al-Futūḥ Aḥmad (d. 1154)

[566] 1. Rasā’ilf fial-handasiyya (Treatises on Geometry), 331 \{16\}. Bound with R. Abīal-Futūh. MANUSCRIPT: SK Ayasofya 4830.

AL-SHIRĀZ̄̄, 'Abd al-Malīk (d. ?)

[567] 1. Tașaffuh al-makhrūtāat (Examinining the Conics), 331 \{8\}. MANUSCRIPT: TSMK A. 3463 (Karatay: A 6995). See $\rightarrow$ Apollonius of Perga, 1.3. 
AL-SHĪRĀZĪ, Quṭb al-Dīn Maḥmūd b. Mas'ūd b. Muṣliḥ (d. 1311)

See also al-Shirāzī in Part Two ('ilm al-hay'a).

[568] 1a. K. durrat al-täj (The Pearly Crown), Persian, 1306, $314\{4\}$. [Only the part on Euclid's Geometry.] Bound with Rāzì's Rawḍtal-munajjiminn, al-Ṭūsì's Zīj-i ìlkhānī, Sayyid Munajjim's K. ahkām al-a'wām, al-Bakrī's Burhān al-kifāya, and Tuhfatal-gharā̉ib. EDITION:Durrat al-tāj, ed. Muhammad Mushkāt (Tehran: Intishārāt-i Hikmat, 1990).

[569] 1b. Same as preceding, $329\{4-5\}$. [Only the Persian translation of the Book of Euclid.]

AL-ṬŪSĪ, Nașīr Al-Dīn Abū Jacfar Muhammad b. Muhammad (d. 1274)

See also al-Ṭūsī in Part One ('ilm al-nujūm), Part Two ('ilm al-hay'a), and Part Three ('ilm al-hisāb).

[570] 1a. Majmū'a min al-mutawassițāt (Middle Books), Arabic, 1265, $331\{2-3\}$. Bound with other texts in geometry. EDITION: Tahrīr-imutavassițāt-i khvāja Nașìr al-Dīn Ṭūsū, with introduction by Ja far Āqāyānī Chāvushī (Tehran: Pazhūhishgāh-i 'Ulūm-i insānī va Muṭāla'at-i farhangī, 2004/2005).

[571] 1b. Same as preceding, $331\{17\}$. Bound with other texts in geometry.

[572] 1c. Same as preceding, $331\{18\}$. Bound in a miscellaneous volume containing K. Uqlïdus, K. tahrīr al-Majisțī, and al-Tadhkira fi al-hay'a. MANUSCRIPT: This codex might be TSMK A. 3453 (Karatay: A 7005).

[573] 2a. K. Tahrīir ușül Uqlïdus (Recension of Euclid's Elements), Arabic, 1248, $326\{3-4\}$. EDITION: Tahrîru usûli'l-hendese ve'l-hisâb:Eukleides'in Elemanlar Kitabının Tahriri, Inceleme-Tıpkıbasımı, facs. of manuscript in Arabic, ed. İhsan Fazlıŏlu (Istanbul: Türkiye Yazma Eserler Kurumu Başkanlığı, 2012).

[574] 2b. Same as preceding, $329\{8\}$.

[575] 2c. Same as preceding, $329\{8-9\}$.

[576] 2d. Same as preceding, $326\{18\}$. MANUSCRIPT: One of the four copies (2a, 2b, 2c, 2d) should be the manuscript now housed as SK Ayasofya 2722.

[577] 2e. Same as preceding, $326\{8-9\}$.

[578] 2f. Same as preceding, $326\{10\}$.

[579] 2g. Same as preceding, 327 \{14\}. Bound with al-Ahwāzî̀s Sharh al-M. al-āshirat min K. Uqlīdus and an unspecified treatise on arithmetic. MANUSCRIPT: This codex $(2 \mathrm{~g})$ should be the copy now housed as SK Ayasofya 2742.

[580] 2 h. Same as preceding, $328\{19\}$. Bound with al-Nasawìs K. tajrìd fı̀ ușül al-handasa and K. alkifāya fì 'ilm al-hisāb. MANUSCRIPT: SK Fatih 3441.

[581] 2i. Same as preceding, $330\{5\}$. Bound with unspecified treatises on different subjects treated in K. Uqlïdus.

[582] 2j. Same as preceding, $331\{9\}$. Bound in a miscellaneous volume containing unspecified treatises on geometry and other subjects. MANUSCRIPT: One of the two copies (2i or $2 \mathrm{j})$ might be Millet Feyzullah 1359.

[583] $2 \mathrm{k}$. Same as preceding, $331\{18\}$. Bound in a miscellaneous volume containing al-Mutawassitāat al-handasiyya, K. Tahrïr al-Majisțī, and al-Tadhkirafíal-hay'a. MANUSCRIPT: This codex might be TSMK A. 3453 (Karatay: A 7005).

\section{ANONYMOUS/UNIDENTIFIED}

[584] 1. K. al-hawāashīfíal-ilm al-rìyāḍ̄ (Book of Supercommentaries on Mathematical Science), 324 $\{12\}$. MANUSCRIPT: SK Ayasofya 2609 . 
[585] 2a. K. da'āwā Uqlïdus min qibal al-handasa, Arabic, 324 \{11\}. Bound with R. al-'amal bi-al-kura al-falakiyya. MANUSCRIPT: This codex (2a) should be the copy now housed as SK Ayasofya 2635 .

[586] 2b. "K. Uqlïdus fi al-handasa," $326\{4\}$.

[587] 3. K. al-handasa wa-al-hay'a wa-ghayrihimā (Anonymous Volume containing books on Geometry and the Science of the Configurations [of the Heavens])], $330\{12-13\}$.

[588] 4. R. al-birkār al-tāmm min qibal al-handasa (Treatise on the Perfect Compass), $331\{14-15\}$. Bound with R.fíal-tashwìq ilā al-hayāt al-dā'ima.

[589] 5a. "R. fi al-handasa wa-ghayrihā," $332\{8-9\}$.

[590] 5b. "R.fíal-handasa," $27\{1-2\}$. Bound with R. țäli'Sulțān Bāyezìd Khan and R.fíal-tafsìr. [Catalogued under Kutub al-tafāsìr wa-kutub 'ilm al-qirä’at.]

[591] 5c. "K. fi al-handasa," 51 \{14-15\}. Bound with R. fi al-wafq. [Catalogued under Kutub al-ad'iya wa-kutub khawāșșal-Qur'ān wa-kutub ilm al-wafq.]

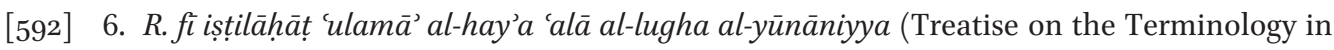
Greek of the Scholars of Astronomy), Greek with translations, $296\{7-8\}$. Bound with K. tuhfa al-hādīya al-mutarjam bi-al-turkiyya wa-al-rūmiyya wa-al-afranjìyya, K. İsāghūj̄ 'alā al-lugha al-'arabiyya al-mutarjam bi-al-yūnāniyya, $R$. al-amthila al-mutțarida al-mutarjama bi-alfārisiyya, R. fì al-ulūm al-ḥikamiyya, R. fì tașhịh asāmī al-h̆ukamā’ al-yūnāniyya. [Catalogued under kutub al-lugha al-'arabiyya wa-al-fārisiyya wa-ghayrihimā.] MANUSCRIPT: TSMK A. 2698 (Karatay: A 8732).

[593] 7. al-Fann al-awwal fì al-handasa wa-al-fann al-thānī fì al-hay'a min riyādiyyāt K. al-Shifäà (Geometry and Astronomy from the Mathematics Part of Ibn Sīnā's The Cure), 351 \{11-12\}. MANUSCRIPT: SK Ayasofya 2720.

[594] 8. K. al-ușūl al-aṣliyya fì al-handasa (Book on the Fundamental Principles in Geometry), 327 $\{6\}$.

\section{PART FIVE}

Music ('ilm al-mūsīqū)

IBN SALAMA, Abū Ṭālib al-Mufaḍḍal (d. ca. 903)

[595] 1. K. al-malāhīwa-asmā’ihà (Book of Musical Instruments and Their Names), Arabic, $337\{1-2\}$. MANUSCRIPT: TSMK A. 2286 (Karatay: A 7423).

AL-LĀDHIQĪ, Muḥammad b. 'Abd al-Ḥamīd (fl. ca. 1483)

[596] 1a. al-R. al-Fathiyya (The Fathiyya Treatise), Arabic, fifteenth century, 336 \{11-12\}. [Catalogued in the inventory as K. Mawlānà Muhyī al-Dìn al-Lādhiqüfì al-mūsīqī.]

[597] 1b. Same as preceding, 336 \{15\}. [Catalogued in the inventory as R. Fathiyya li-Mawlānā Muhỹ̄ al-Dìn al-Lādhiqüfì al-mūsīqī.]

[598] 2. Zayn al-alhän (The Adornment of Melodies in Turkish on Music), Turkish, fifteenth century, $337\{3-4\}$. MANUSCRIPT: SK Nuruosmaniye 3655 contains the Arabic version of Zayn al-alhān that bears Bayezid II's seal.

AL-MARĀGHĪ, 'Abd al-'Azīz b. 'Abd al-Qādir b. Ghaybī (fl. late fifteenth century)

[599] 1a. Naqāwat al-adwār (Best of the Modes), Persian, $335\{16\}$.

[6oo] 1b. Same as preceding, $336\{18\}$. 
[601] 1c. Same as preceding, $337\{3\}$. MANUSCRIPT: One of these three codices should be the copy now housed as TSMK A. 3462 (Karatay: F 278).

AL-MARĀGHĪ, 'Abd al-Qādir b. Ghaybī (d. 1435)

[602] 1a. Jāmi' al-alhāan (Compendium of Melodies), Persian, 1415, 336 \{3-4\}. EDITION: Jāmi` alalhānn, ed. Taqī Bīnish (Tehran: Mu'assasa-yi Muțāla'at va Taḥqīqāt-i Farhangī, 1987).

[603] 1b. Same as preceding, $336\{4-5\}$. MANUSCRIPT: These two codices (1a and $1 \mathrm{~b}$ ) should be SK Nuruosmaniye 3644 and 3645 .

[604] 2a. Maqāṣid al-alhān (Meaning of Melodies), Persian, 1418, $335\{17\}$.

[605] 2b. Same as preceding, $336\{7-8\}$. MANUSCRIPT: One of the two copies (2a and $2 \mathrm{~b}$ ) should be TSMK R. 1726 (Karatay: F 279). EDITION: Maqāṣid al-alhān, ed. Taqī Bīnish (Tehran: Bungāh-i Tarjama va Nashr-i Kitāb, 1966).

[606] 3a. Sharh k. al-adwār, Persian, $335\{19\}-336$ \{1\}. See $\rightarrow$ al-Urmawī, 1.1. MANUSCRIPT: TSMK A. 3470 (Karatay: F 280). EDITION: Sharh-i adwār (bā matn-i adwār wa-zawā̄id al-fawāidd), ed. Taqī Bīnish (Tehran: Markaz-i Nashr-i Dānishgāhī, 1992).

[607] 3b. Same as preceding, $336\{1-2\}$. Bound with al-Marāghï’s $R$. fawā’id-i ishra. ${ }^{42}$

[608] 4a. R. fawā'id-i 'ashara (Ten Scholia), Persian, 336 \{2-3\}. Bound with al-Marāghìs Sharh k. al-adwār.

[609] 4b. Same as preceding, $336\{10-11\}$.

[610] 5. R. lahniyya (Treatise on Melodies), $336\{9-10\}$.

[611] 6. "K. 'Abd al-Qādir al-Marāghīfíal-mūsīqū," $336\{6-7\}$. Bound in a miscellaneous volume.

AL-SHIRWĀNĪ, Fatḥ Allāh b. Abū Yazīd b. 'Abd al-'Azīz b. Ibrāhīm al-Shābarānī (d. 1486)

See also al-Shirwānī in Part Two ('ilm al-hay'a).

[612] 1a. Majalla fì al-mūsìqü (Codex on Music), Arabic, $335\{18\}$.

[613] 1b. Same as preceding, $336\{5\}$. MANUSCRIPT: One of these two codices should be the copy now housed as TSMK A. 3449 (Karatay: A 7428). EDITION: Majalla fi al-mūsíqī = Codex on Music, facs. ed. of TSMK A. 3449, ed. Fuat Sezgin (Frankfurt: Institut für Geschichte der Arabisch-Islamischen Wissenschaften, 1986).

[614] 2. Tarjama-i adwār-i Khoja Șafi al-Dīn (Translation of al-Urmawī's Epitome), Persian, 333 \{18-19\}. Bound with al-Wālishtānī's Mukhtașar dar 'ilm al-ḥisāb. MANUSCRIPT: SK Ayasofya 2735. See $\rightarrow$ al-Urmawī, $1(i)$.

AL-URMAWĪ, Șafì al-Dīn 'Abd al-Mu’min b. Yūsuf b. Fākhir (d. 1294)

[615] 1a. al-Mukhtașar fì ma'rifat al-nagham wa-al-adwār (Epitome on Understanding Musical Tunes and Modes), better known as K. al-adwār (The Book of the Modes), Arabic, 1236, 336 \{13-14\}. [Catalogued in the inventory as Mukhtașar Șafial-Dìnfíal-mūsīqī.] MANUSCRIPT: This codex (1a) should be the copy now housed as SK Ayasofya 2735. EDITION: Mehmed Nuri Uygun, Safiyüddin Abdulmumin Urmevive Kitabü'l-Edvar'ı (Istanbul: Kubbealtı, 1999).

[616] 1b. Same as preceding, $336\{17\}$.

[617] 1c. Same as preceding, $337\{1\}$. [Catalogued in the inventory as Mukhtașar fi ma'rifat alnagham.]

[618] 1(i). [al-Shirwānī.] Tarjama-i adwār-i Khoja Șafĭ al-Dīn, Persian, 333 \{18-19\}. Bound with alWālishtānī's Mukhtașar dar 'ilm al-hisāab. MANUSCRIPT: SK Ayasofya 2735. See $\rightarrow$ al-Shirwān̄̄.

[619] 1(ii). "Tarjama-i mukhtașar-i Șafì al-Dīn fì al-mūsīqı̄," Persian, 336 \{14-15\}. 
[620] 1.1. [al-Marāghī.] Sharh k. al-adwār, Persian, $335\{19\}-336$ \{1\}. See $\rightarrow$ Al-Marāghī, 'Abd al-Qādir b. Ghaybī, 3. MANUSCRIPT: TSMK A. 3470 (Karatay: F 280).

[621] 2a. al-R. al-sharafiyya fi al-nisab al-ta'lifiyya (The Sharafiyya Treatise on Musical Proportions), Arabic, 1267, 335 \{16\}. EDITION: Fazlı Arslan, Safiyyüddin Urmevi ve Şerefiyye Risalesi (Ankara: Atatürk Kültür Merkezi, 2007).

[622] 2b. Same as preceding, $335\{18-19\}$.

[623] 2c. Same as preceding, $336\{17-18\}$.

ANONYMOUS/UNIDENTIFIED AUTHORS

[624] 1. Kashf al-humüm wa-al-kurab fi sharh äla al-țarab (Dispelling Worries and Distress on the Description of a Musical Instrument), Arabic, fourteenth century, $336\{8\}$. MANUSCRIPT: TSMK A. 3465 (Karatay: A 7424). EDITION: Mehmet Tıraşç1, “Kitâbü Keşfü'l-Hümûm ve'l-Kürab fî şerhi âleti't-tarab isimli Anonim Mûsikî Eseri (Edisyon Kritik ve İnceleme” (PhD diss., Marmara University, 2013).

[625] 2. Mukhtașarfíal-mūsīqü (Compendium of Music), language specified as Arabic, $336\{9\}$.

[626] 3. Sharh al-mukhtașar fíal-mūsīqü (Commentary of the Musical Compendium), $336\{12\}$.

[627] 4a. R. fì al-mūsīqü (Treatise on Music), language specified as Persian, $336\{12-13\}$.

[628] 4b. Same as preceding, language specified as Turkish, $337\{4-5\}$.

[629] 4c. "K. fìal-mūsīqū," language specified as Arabic, $337\{4\}$.

[630] 5. Muwashshah jāmi al-maqāmāt wa-ghayrihā min qibal al-mūsīqū (A Compendium of Muwashshah Works on [musical] Rhythms), $336\{16\}$.

[631] 6a. Gharāìb al-adwār fì al-mūsīqü (Unusual Modes), $336\{13\}$.

[632] 6b. Same as preceding, $337\{2\}$.

[633] 7. Adwār al-mūsīqü (Musical Modes), 336 \{19\}. Bound with an anonymous R. manžümafi hikāya müsīqiyya.

[634] 8. R. manzūma fi hikāya mūsīqiyya (Treatise in Verse on the Story of Music), Persian, $336\{19\}$. Bound with an anonymous Adwār al-mūsìqi.

PART SIX

Amusement (kutub al-lahw)

AL-ḤASAN AL-BAȘRĪ, Abū Sa'īd al-Ḥasan b. Yasār al-Bașrī (d. 728)

[635] 1a. K. al-shațranj li-l-Bașrī (The Book of Chess), Arabic, $337\{12\}$.

[636] 1b. Same as preceding, $337\{12\}$.

[637] 1c. Same as preceding, $337\{13\}$.

ANONYMOUS/UNIDENTIFIED

[638] 1. K. al-shațanj, $337\{13\}$.

\section{NOTES}

Authors'note: This list includes helpful contributions from Jamil Ragep and the McGill Team (Sally Ragep, Sajjad Nikfahm-Khubravan, Fateme Savadi, and Hasan Umut).

1. Karatay does not list all the works in the volume.

2. This codex is not catalogued in Karatay. 
3. 'Atufi notes that the book is also known as $K$. al-tāj.

4. Since we did not have the chance to see the original manuscript, we are not sure whether this codex bears Bayezid II's seal.

5. Karatay says the work is anonymous.

6. Although 'Atufi does not assign its authorship to Kūshyār, the extant volume contains his treatise on the astrolabe along with Ptolemy's Tasțịh basit al-kura (Flattening the Surface of the Sphere) and Thābit b. Qurrā's translation of Autolykos (K. al-kura al-mutaharriqa).

7. 'Atufi notes that the copy lacks the last part of Book 4.

8. The codex has the seal of Bayezid II and is listed by Zeynep Atbaş. But as Jamil Ragep et al. have noted, Karatay also lists a treatise by Taqī al-Dīn $(\mathrm{d} .1585)$ bound in the same volume. This codex might have been rebound at a later date.

9. See the above footnote.

10. Although 'Atufi does not mention it in the relevant entry, the copy also includes a section from Book 4 of al-Shīrāzì’s Durrat al-tāj.

11. 'Atufi notes that the copy contains only Chapter 7 .

12. Karatay does not list all the works in the volume.

13. This codex is not catalogued in Karatay.

14. Karatay does not list all the works in the volume.

15. Although 'Atufi does not mention it in the relevant entry, this codex also contains Miftāh bisst bāb dar ma'rifat-i usțurlāb attributed to al-Ṣūfî.

16. Although 'Atufi does not mention it in the relevant entry, the copy also includes a section from Book 4 of al-Shīrāzì's Durrat al-tāj.

17. Karatay does not list all the works in the volume.

18. The manuscript also contains the Turkish translation of the same horoscope.

19. Although 'Atufi does not mention it in the relevant entry, this volume contains a copy of Kūshyār's Mujmal al-ușūl.

20. Karatay does not list all the works in the volume.

21. Karatay does not list all the works in the volume.

22. Although 'Atufi does not specify its authorship to Kūshyār, the extant volume houses his treatise on the astrolabe along with Ptolemy's Tasțịh basit al-kura (Flattening the Surface of the Sphere) and Thābit b. Qurrā's translation of Autolykos's K. al-kura al-mutaharriqa.

23. Although 'Atufi does not mention it in the inventory, the extant copy also contains three additional texts on astral sciences: al-Ṭūsī’s al-R. al-mu'iniyya, Sharh R.-i mu'iniyya, and Mukhtașar dar ma'rifat-i usturlāb.

24. Although 'Atufi does not mention it in the relevant entry, the extant copy also contains three additional texts on astral sciences: al-Ṭūsī's al-R. al-mu'iniyya, Sharh R.-i mu'iniyya, and Mukhtașar dar ma'rifat-i usțurlāb.

25. 'Atufi's entry does not specify its authorship to Fath Allāh al-Shirwānī, but given that in addition to al-Niksārì's supercommentary, there are two additional supercommentaries in the palace library, one written by al-Shirwānī and the other by Sinān Pasha, one of these two entries must be referring to al-Shirwānī's work.

26. 'Atufi's entry does not specify its authorship to Sinān Pasha, but given that in addition to al-Niksārî’s supercommentary, there are two additional supercommentaries in the palace library, one written by al-Shirwānī and the other by Sinān Pasha, one of these two entries must be referring to Sinān Pasha's work.

27. Based on extant manuscript record, one of the unidentified commentaries listed under al-Ṭūsī should be al-Jurjānī's work.

28. See note $\mathrm{xxv}$ above.

29. See note xxvi above.

30. As far as the relevant catalog entry of Karatay is concerned, the manuscript contains different treatises, including that of al-Ṭūī and al-Sijzì.

31. See note xxvi above.

32. See note $x x v$ above.

33. Based on extant manuscript record, one of the unidentified commentaries listed under al-Tūūì should be al-Shirwānī's work. 
34. Although the work has been attributed to Qāḍizāde al-Rūmī, İhsan Fazlıŏlu notes that it should belong to another Șalāḥ al-Dīn Mūsā who lived and flourished before Qāḍīzāde al-Rūmī. See Fazlıŏ̆lu, "Kadızade-i Rumi," Türkiye Diyanet Vakfi İslam Ansiklopedisi.

35. According to both the Karatay catalogue and the catalogue of the Süleymaniye Library, the author of this work bearing Bayezid II's seal is a certain Shams al-Dīn Muhammad al-Khațībì. No information has been found about this individual.

36. Cevat İzgi records the title as al-Tajnis fı al-hisāb. See Cevat İzgi, Osmanlı Medreselerinde İlim, vol. 1 (Istanbul: İz, 1997), 245-46.

37. 'Atufi registers the title as hussāb.

38. The catalogue of the Süleymaniye Library attributes it to al-Tūisì.

39. Jamil Ragep et al. note that the codex contains Fanārīzāde 'Alī Çelebī's commentary on Sajāwāndi's al-Tajnis. The listing on the title page corresponds with 'Atufi's entry in the inventory.

40. This could be the work of Ibn al-Haytham.

41. This could be 'Abd Allāh b. Muhammad b. Kiya al-Māzandarān̄’s Risāla-i falakiyya. See Die Resalä-ye falakiyyä des 'Abdollah ibn Mohammad ibn Kiya al-Mazandarani: Ein persischer Leitfaden des staatlichen Rechnungswesens (um 1363), ed. Walther Hintz (Wiesbaden, 1952).

42. While MS Török F. 59 transliteration reads it as 'ishra, the entry on Marāghī in the Türkiye Diyanet Vakfi İslam Ansiklopedisi reads it as 'ashara. 